\title{
JAN 41988
}

\section{Inhalation Developmental}

Toxicology Studies of

1,3-Butadiene in the Rat
P. L. Hackett
J. R. Decker
M. R. Sikov
J. J. Evanoff
T. J. Mast
R. L. Rommereim
M. G. Brown
S. E. Rowe
R. L. Buschbom
M. L. Clark
R. B. Westerberg

November 1987

Prepared for the DO NOT MICROFILM National Institute of Environmental COVER Health Sciences, National Toxicology Program under a Related Services Agreement with the U.S. Department of Energy Contract DE-AC06-76RLO 1830

Pacific Northwest Laboratory Operated for the U.S. Department of Energy by Battelle Memorial Institute 


\section{DISCLAIMER}

This report was prepared as an account of work sponsored by an agency of the United States Government. Neither the United States Government nor any agency Thereof, nor any of their employees, makes any warranty, express or implied, or assumes any legal liability or responsibility for the accuracy, completeness, or usefulness of any information, apparatus, product, or process disclosed, or represents that its use would not infringe privately owned rights. Reference herein to any specific commercial product, process, or service by trade name, trademark, manufacturer, or otherwise does not necessarily constitute or imply its endorsement, recommendation, or favoring by the United States Government or any agency thereof. The views and opinions of authors expressed herein do not necessarily state or reflect those of the United States Government or any agency thereof. 


\section{DISCLAIMER}

Portions of this document may be illegible in electronic image products. Images are produced from the best available original document. 


\section{DISCLAIMER}

This report was prepared as an account of work sponsored by an agency of the United States Government. Neither the United States Government nor any agency thereof, nor Battelle Memorial Institute, nor any of their employees, makes any warranty, expressed or implied, or assumes any legal liability or responsibility for the accuracy, completeness, or usefulness of any information, apparatus, product, or process disclosed, or represents that its use would not infringe privately owned rights. Reference herein to any specific commercial product, process, or service by trade name, trademark, manufacturer, or otherwise, does not necessarily constitute or imply its endorsement, recommendation, or favoring by the United States Government of any agency thereof, or Battelle Memorial Institute. The views and opinions of authors expressed herein do not necessarly state or reflect those of the IIniter States Sinvernment or any agency thereof, or Battelle Memorial Institute.

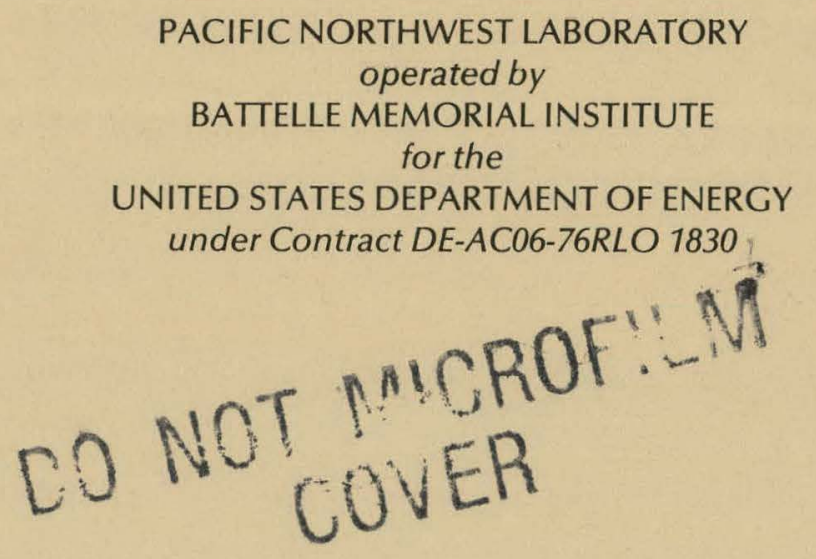


This report was prepared as an account of work sponsored by an agency of the United States Government. Neither the United States Government nor any agency thereof, nor any of their employees, makes any warranty, express or implied, or assumes any legal liability or responsibility for the accuracy, completeness, or usefulness of any information, apparatus, product, or process disclosed, or represents that its use would not infringe privately owned rights. Reference herein to any specific commercial product, process, or service by trade name, trademark, manufacturer, or otherwise does not necessarily constitute or imply its endorsement, recommendation, or favoring by the United States Government or any agency thereof. The views and opinions of authors expressed herein do not necessarily state or reflect those of the United States Government or any agency thereof.

INHALATION DEVELOPMENTAL TOXICOLOGY STUDIES OF 1,3-BUTADIENE IN THE RAT

PNL--6414

DE88 004186

Final Report

No. NIH-401-ES-40131

P. L. Hackett

M. R. Sikov

T. J. Mast

M. G. Brown

R. L. Buschbom

M. L. Clark
J. R. Decker

J. J. Evanoff

R. L. Rommereim

S. E. Rowe

R. B. Westerberg

November 1987

Prepared for the

National Institute of Environmental

Health Sciences, National Toxicology

Program under a Related Services

Agreement with the U.S. Department of

Energy under Contruet D[-ACOG-7GRLO $=1830$

Pacific Northwest Laboratory

Richland, Washington 99352 


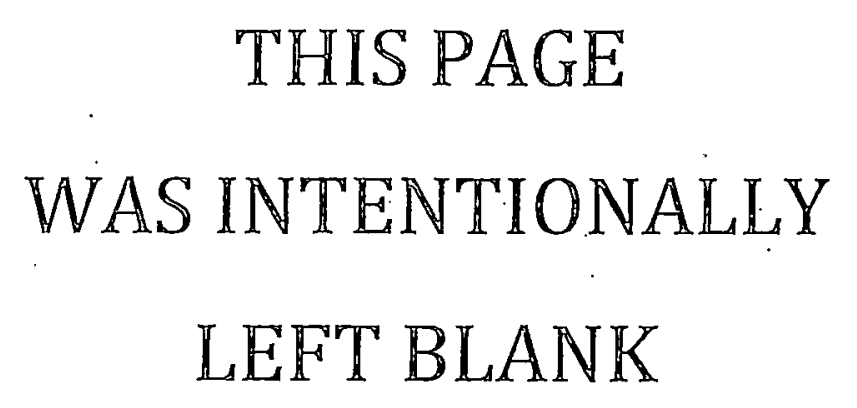

THIS PAGE WAS INTENTIONALLY LEFT BLANK 
Responsibility

Principal Investigators

Exposure System

MonitoringIAnalytical Chemistry

Animal Resources Center

Teratologic Evaluations

Statistical Analyses

ॠTask Leaders
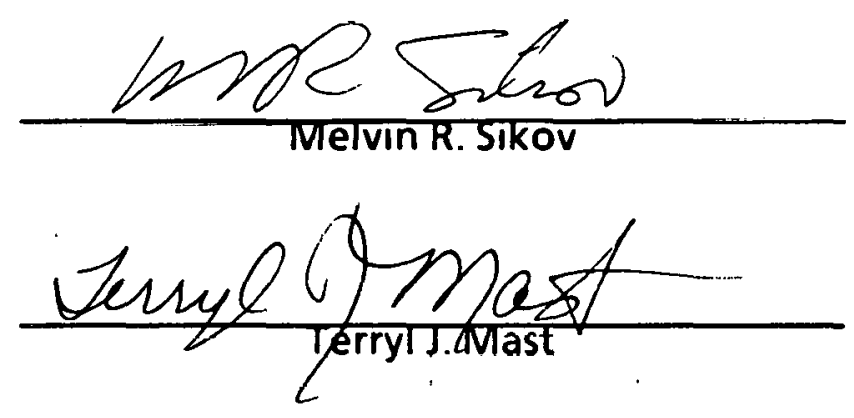

Name

P.L. Hackett*

M.R. Sikov

T.J. Mast

M.L. Clark*

J.R. Decker*

G.R. ElI

L.G. Florek

D.K. Hammerberg

E.M. Milliman

E.J. Rossignol

R.D. Swanneck

M. McCulloch

N.S. Stamps

K.H. Stoney

R.B. Westerberg *

M.G. Brown*

S.E. Rowe ${ }^{\star}$

A.E. Jarrell

P.L. Hackett*

M.R. Sikov

J.J. Evanoff

R.L. Rommereim

T.T. Sherer

M.L. Sours

B.L. Champion

B.J. Willemsen

R.C. Zangar

T.A. Breier

S.A. Quinn

R.L. Buschbom* 


\section{ACKNOWLEDGMENTS}

We wish to express our appreciation to the following members of the staff for their contributions to this project: EJ Rossignol, GR Ell, RD Swannack, LG Florek, EM Milliman, DK Hammerberg, M McCulloch, N Stamps, and KH Stoney for their work on the generation and monitoring system; WB Peterson, VL Dedmond, JT Pierce, and $A E$ Jarrell for animal care and health screening; and J Kaschmitter and DN Rommereim for work on data-acquisition systems. We are especially appreciative of the members of the reproductive toxicology working group: $T$ Sherer, ML Sours, BL Champion, BJ Willemsen, RC Zangar, TA Breier, and SA Quinn. 


\section{ABSTRACT}

Maternal toxicity, reproductive performance and developmental toxicology were evaluated in Sprague-Dawley-derived rats during and following 6 hours/day, whole-body, inhalation exposures to 0 (filtered air), 40, 200 and $1000 \mathrm{ppm}$ of 1,3butadiene. The female rats ( $\mathrm{Ns}=24$ to 28 ), which had mated with unexposed males (day of sperm detection $=0$ days of gestation; $\mathrm{dg}$ ), were exposed to the chemical from 6 through $15 \mathrm{dg}$ and sacrificed on $20 \mathrm{dg}$.

Maternal animals were weighed prior to mating and on $0,6,11,16$ and $20 \mathrm{dg}$; the rats were observed for mortality, morbidity and signs of toxicity during exposure and examined for gross tissue abnormalities at necropsy. Reproductive measures included the determination of numbers of implantation sites, resorptions and live and dead fetuses. Live fetuses were weighed and subjected to external, visceral and skeletal examinations to detect growth retardation and morphologic anomalies.

There were no significant differences among treatment groups in maternal body weights or extragestational weights of rats exposed to 1,3-butadiene concentrations of 40 or 200 ppm, but, in animals exposed to 1000 ppm, significantly depressed body weight gains were observed during the first 5 days of exposure and extragestational weight gains tended to be lower than control values. These results, and the absence of clinical signs of toxicity, were considered to indicate that there was no maternal toxicity at exposure levels of $200 \mathrm{ppm}$ or lower. The percentage of pregnant animals and the number of litters with live fetuses were unaffected by treatment.

Placental weights, fetal body weights and sex ratios were unaffected by treatment. There were no significant differences among groups in incidences of fetal malformations. However, in the 200-ppm exposure group, a significant increase in the incidence of reduced sternebral ossification was detected when the analyses were based on the number of affected fetuses but not on the number of affected litters. This difference could not be correlated with fetal body weights or exposure regimens and was not considered to be treatment-related. There were also irregularities in the thoracic vertebrae, but the incidence of reduced ossification in fetuses 
of the control group was significantly higher than in fetuses of the 200- and 1000ppm exposure groups.

Under the conditions of this exposure regimen, there was no evidence for a teratogenic response to 1,3-butadiene exposure. 


\section{CONTENTS}

Page

LIST OF PERSONNEL FOR TERATOLOGY STUDIES OF 1,3-BUTADIENE $\ldots \ldots \ldots$ iii

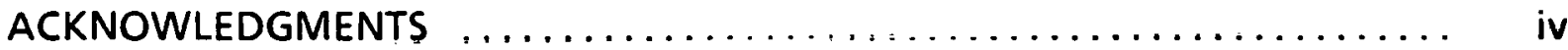

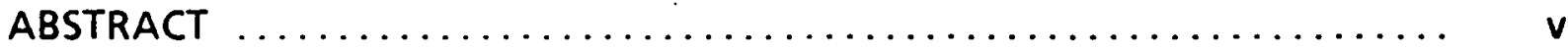

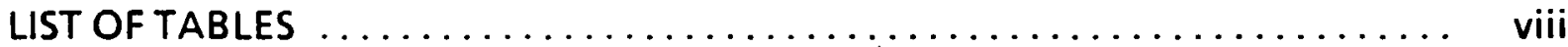

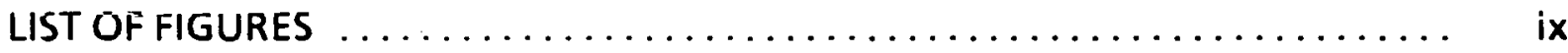

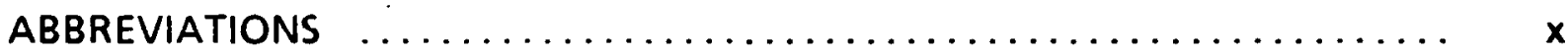

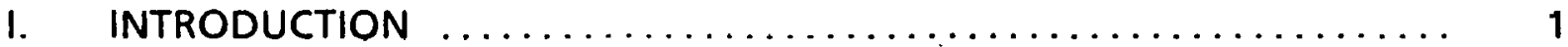

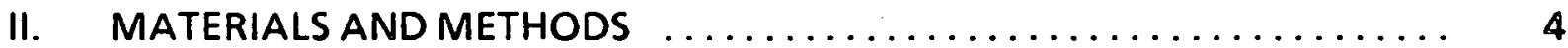

A. PROCUREMENT AND CHARACTERIZATION OF 1,3-BUTADIENE $\ldots 4$

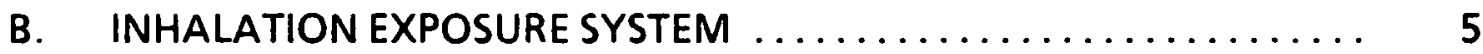

C. ANIMAL HUSBANDRY AND EXPOSURE PROCEDURES $\ldots \ldots \ldots \ldots, 8$

D. TOXICOLOGIC AND DEVELOPMENTAL OBSERVATIONS $\ldots \ldots \ldots, 10$

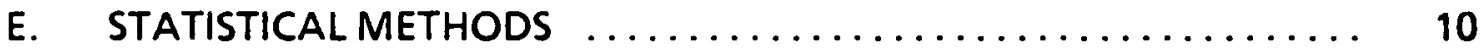

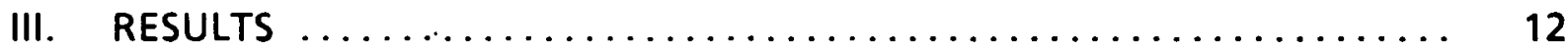

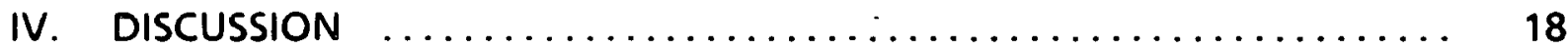

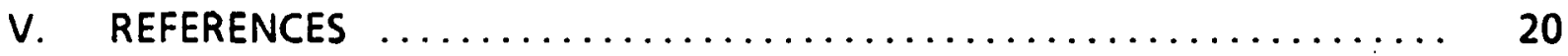

\section{APPENDICES}

A. ANALYTICAL DATA FOR 1,3-BUTADIENE (LOT NUMBER F909)

B. BUTADIENE CONCENTRATIONS, TEMPERATURE, AND RELATIVE HUMIDITY MEASUREMENTS IN THE EXPOSURE CHAMBERS

C. CHAMBER UNIFORMITY TESTS FOR 1,3-BUTADIENE CONCENTRATIONS

D. HEALTH EVALUATIONS OF EXPERIMENTAL ANIMALS

E. INDIVIDUAL VALUES FOR FETAL STATUS, SEX AND BODY WEIGHT, AND PLACENTAL WEIGHT

F. INDIVIDUAL MATERNAL BODY AND UTERINE WEIGHTS 
G. MALFORMATIONS AND VARIATIONS IN INDIVIDUAL RAT FETUSES EXPOSED TO 1,3-BUTADIENE

H. QUALITY ASSURANCE STATEMENT, SAMPLE AND RECORD DISPOSITION, SCHEDULE OF EVENTS, AND REPRODUCTIVE INDICES FROM RAT 1,3BUTADIENE DATA

\section{LIST OF TABLES}

Page

1. Summary of Exposure Chamber Atmospheric Concentrations of 1,3Butadiene During the Developmental Toxicology Study in the Rat .....

2. 4-Vinyl-1-Cyclohexene (Dimer) Concentrations in the Atmosphere of the 1000-ppm 1,3-Butadiene Chamber of the Teratology Study with Rats ..

3. Experimental Design for Teratology Study of Rats Exposed tu 1,3-

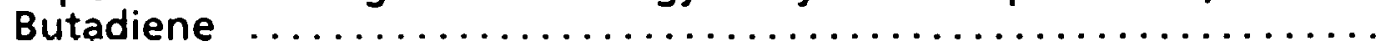

4. Changes in Body Weights ( $g$, Mean \pm Standard Error) of Pregnant Rats

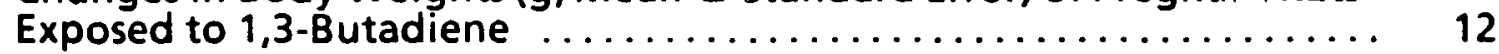

5. Maternal Measures ( $g$, Mean \pm Standard Error) for Rats Exposed to

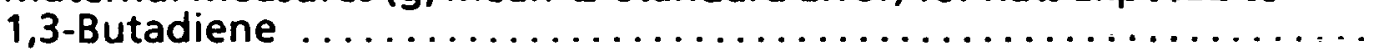

6. Reproductive Measures (Mean \pm Standard Error) for Rats Exposed to 1,3-Butadiene

7. Fetal and Placental Measures (Mean \pm Standard Error) for Rat Litters Exposed to 1,3-Butadiene

8. Malformations in Fetuses of Rats Exposed to 1,3-Butadiene ........ 15

9. Fetal Variations in Rats Exposed to 1,3-Butadiene .............. 16

10. Mean Percent of Reduced Ossification or Hydroureter per Litter Following Exposure to 1,3-Butadiene (Mean \pm Standard Deviation) ..........

B1. Exposure Chamber Atmospheric Concentrations (Mean Daily Concentration \pm Standard Deviation) of 1,3-Butadiene During the Teratology

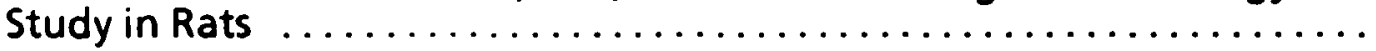

B2. Exposure Chamber Temperatures $\left({ }^{\circ} \mathrm{F}\right.$, Daily Mean \pm Standard Deviation) for the Teratology Study of 1,3-Butadiene in Rats

B3. Exposure Chamber Relative Humidity $(\mathrm{RH} ; \%$, Daily Mean \pm Standard Deviation) for the Teratology Study of 1,3-Butadiene in Rats .........

C1. 1,3-Butadiene Gas Concentration Uniformity Test 


\section{LIST OF FIGURES}

Page

1. Buildup and Decay of the Atmosphere of the 1000-ppm 1,3-Butadiene Exposure Chamber in the Presence and Absence of Animals

A1. Gas Chromatogram of 1,3 -Butadiene ..................... A

A2. Gas Chromatogram of 1,3-Butadiene Dimer $\ldots \ldots \ldots \ldots \ldots \ldots$ A-4

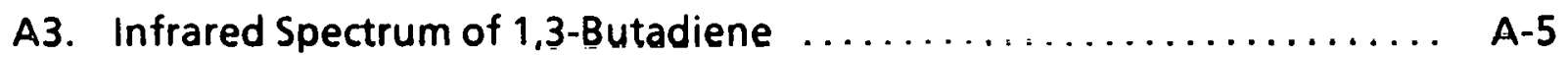

C1. Chamber Uniformity Data Sheet--Gas Chromatography Monitoring ... C-2

C2. Chamber Uniformity Data Sheet--Chamber Balance $\ldots \ldots \ldots \ldots \ldots$ C-3 


\section{ABBREVIATIONS}

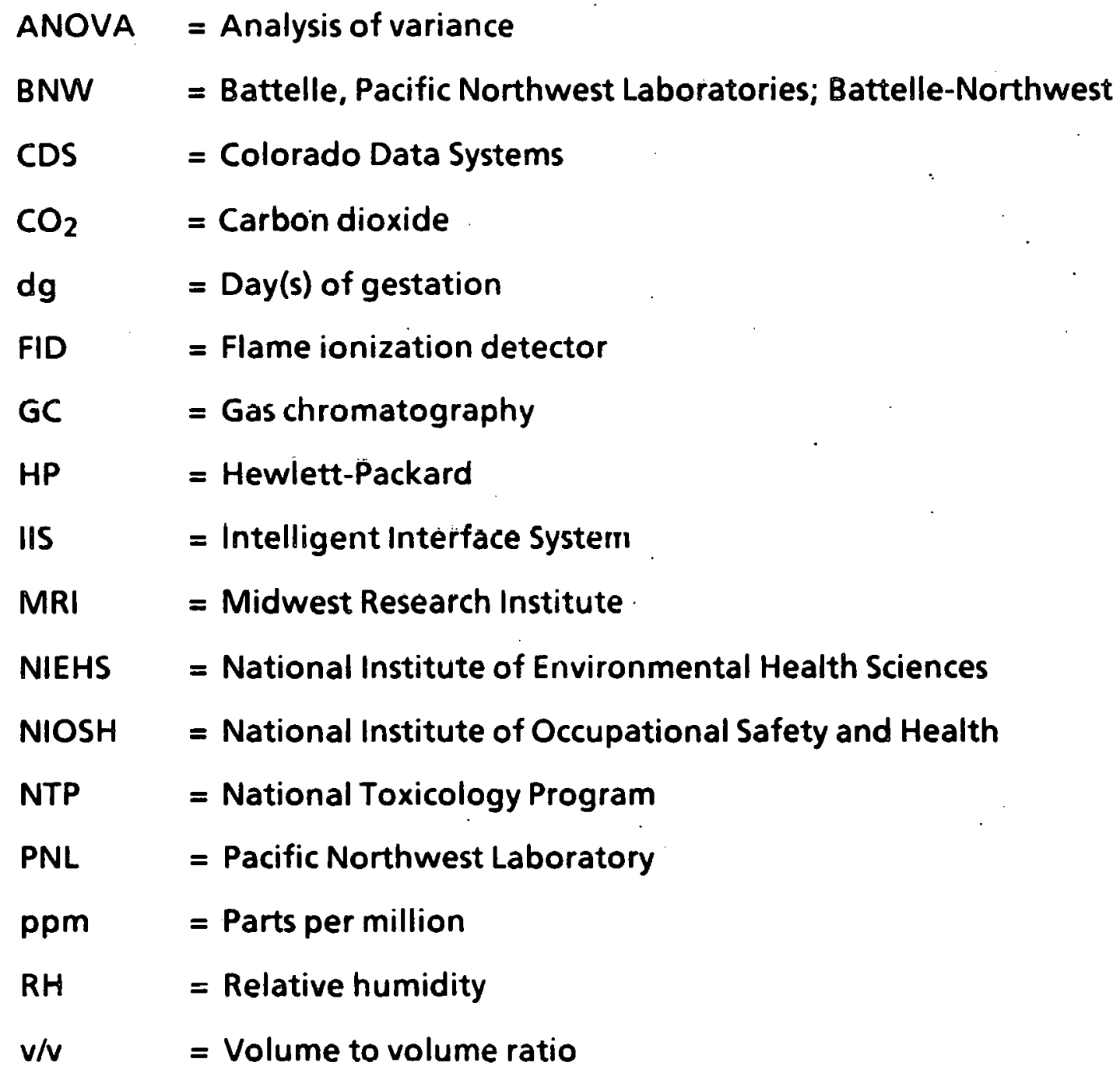




\section{INTRODUCTION}

The major uses of butadiene are in the manufacture of styrene-butadiene rubber, in the production of polymers, and as a chemical intermediate (SRI, 1979). The major manufacturers in the U.S. produced about 1.5 million tons in 1980 (SRI, 1981), and it has been estimated that about 62,000 workers were exposed (National Institute of Occupational Safety and Health [NIOSH], 1980). As with most chemicals, accidental release during their transportation poses a potential for exposure of the general population. From reviews of the literature, it appears that acute exposure to 1,3-butadiene is not highly toxic and that mice are more sensitive than rats when exposed by either oral or inhalation routes.

There are indications that chronic inhalation exposure to 1,3-butadiene alters the reproductive system. In a study in rats (Hazelton, 1981), euthanasia was required for females with large mammary tumors and males with severe nephropathic changes after 24 months of exposure to 1000 to $8000 \mathrm{ppm}$ of butadiene. In this study, there was an increased incidence of a number of tumor types, including those of the reproductive tract (Leydig cell tumors of the testes and uterine/vaginal stromal tumors). Another study, performed by Battelle, Pacific Northwest Laboratories (Battelle-Northwest; BNW) for the National Toxicology Program (NTP) in 1981 (BNW, 1984), in which mice were exposed to 625 and $1250 \mathrm{ppm}$ of butadiene, was terminated at about 60 weeks because of high mortality associated with neoplasms at multiple sites, including ovarian granulosa cell tumors. There was also a significantly increased incidence of mice with testicular or ovarian atrophy.

There appear to be only two studies reported in which the reproductive and developmental toxicity of inhaled 1,3-butadiene was specifically evaluated. In one of these studies, exposure of rats to 600,2300 and $6700 \mathrm{ppm}$ of butadiene for 8 months resulted in a concentration-related depression of body weight (Carpenter et al., 1944). Reproductive studies of male and female animals were performed at unstated times during these exposures, but no data were given concerning the number of matings, or of barren females. The number of litters/female rat in all exposed groups tended to be lower than in controls, although litter sizes were stated to slightly exceed the "expected norm" of six/litter. Limited breeding tests of the offspring in the 2300 - and 6700-ppm exposure groups suggested that there was 
reduced fecundity, but it was not determined whether the deficit was associated with the males or with the females. Although details were not provided, 12 guinea pigs and 4 rabbits of each exposure group were also used for reproductive studies. Animals of all groups evidently produced progeny, except for rabbits exposed to 600 and $2300 \mathrm{ppm}$. The data are not supportive of the authors' conclusion that butadiene exposure did not affect reproductive performance and that any apparent reduction in fertility was due to hereditary characteristics.

In the other study, female rats were exposed to $0,200,1000$ and $8000 \mathrm{ppm}$ of butadiene from 6 through 15 days of gestation (dg; Hazelton, 1982). There was a significant concentration-related suppression of maternal body-weight gains during exposure, but body-weight gains during gestation (adjusted for conceptus weight) were significantly depressed only in animals exposed to the two highest concentrations. Reproductive measures (pregnancy rate, gravid uterus weight, number of implantation sites, number of fetuses per dam and preimplantation loss) were not affected by butadiene exposure. Mortality of postimplantation embryos tended to be slightly higher in all groups of exposed animals than in controls but the difference was statistically significant only at the highest concentration.

Body weights and crown-rump lengths of fetuses of the highest exposure group were significantly less than those of control fetuses. There was a significant increase in minor fetal defects (hematomas and minor skeletal defects) in all groups, and exposure to 1000 or $8000 \mathrm{ppm}$ resulted in significantly higher incidences of major skeletal defects. In the $8000-\mathrm{ppm}$ exposure group, there were significant increases in the incidence of other anomalies, including lens opacities and irregular ossification. The incidence of wavy ribs, which was rarely observed in their historical controls, was $1.6 \%$ in the control animals for this study, and increased in a concentration-related manner for exposed animals. The authors concluded that this response was not indicative of a teratogenic effect, but was due to maternally mediated embryonic growth retardation.

These indications of deleterious reproductive and developmental effects of 1,3-butadiene, together with quantitative uncertainties in the limited literature dealing with this widely used material, suggested a need for further investigation. The purpose of the study described in this report was to determine the reproductive and teratologic effects of inhalation exposure to 1,3-butadiene in outbred rats of 
Sprague-Dawley derivation. Because it was important to confirm and extend the findings reported by Hazelton (1982), this study used the same strain of rats, but from a different source. The exposure regimen included two of the atmospheric concentrations ( 200 and $1000 \mathrm{ppm}$ ) that were used in the Hazelton study; in addition, a lower concentration ( $40 \mathrm{ppm}$ ) was used in an attempt to determine a level that was not overtly toxic. Furthermore, it was desirable that the results from this study be compared with data from another rodent, the mouse, in which 1,3butadiene has been reported to be more toxic than in the rat (BNW, 1984). Accordingly, a separate teratology study in CD-1 mice has also been performed in this laboratory, using an identical exposure regimen, and will be described in a separate report. 


\section{MATERIALS AND METHODS}

\section{A. PROCUREMENT AND CHARACTERIZATION OF 1,3-BUTADIENE}

The procurement of 1,3-butadiene from Phillips Chemical Company (Borger, TX) and its initial chemical characterization by Midwest Research Institute (MRI; Kansas City, MO) were arranged by the National Institute of Environmental Health Sciences (NIEHS). The chemical composition of Lot Number F-858, Batch 06, which was analyzed by Phillips Chemical Company, was reported by MRI on July 23, 1985 to be $99.84 \% 1,3$-butadiene, $0.13 \%$ cis(butene) $2,0.03 \%$ heavles (residues remaininy following evaporation of 1,3-butadiene at room temperature), and $13 \mathrm{ppm}$ of the peroxide inhibitor, t-butyl catechol.

For this study, a single lot (F-909) of 1,3-butadiene was packaged in three 28gal steel cylinders and shipped directly from Phillips Chemical Company to Pacific Northwest Laboratory (PNL). The cylinders were fitted with double-entry valves, which permitted sampling of liquid 1,3-butadiene through an eductor tube or gaseous material through a valve from the cylinder headspace. As received, the testmaterial cylinders contained variable amounts of nitrogen, which had been used by the manufacturer to dispense the 1,3-butadiene from bulk storage into appropriate containers for off-site shipment. The nitrogen was released from the cylinders prior to the withdrawal of 1,3-butadiene for analyses or animal exposures. A single cylinder (BNW 50846-36-2) was used for the animal exposures of 14 days' duration in the study described in this report.

Procedures for reanalysis of bulk chemicals were provided by MRI, and the materials were analyzed in our laboratory prior to the initiation of the animal exposures. The infrared spectrum of Lot Number F-909 of 1,3-butadiene (400 to 600 $\mathrm{cm}^{-1}$, using a gas cell with $\mathrm{NaCl}$ windows) confirmed its identity and did not detect major impurities (Appendix A). Data were consistent with the spectrum of Lot Number F-858 and with values obtained from the literature (Erley and Blake).

Gas chromatographic analysis $\left(2 \mathrm{~m} \times 2 \mathrm{~mm}\right.$ Porapak QS $100 / 120,100^{\circ} \mathrm{C}$ isothermal, flame ionization detector; FID) of 1,3-butadiene for this study determined purity to be $99.88 \%$ (Appendix A). An unidentified minor peak, which eluted from 
the column 2 minutes later than the 1,3-butadiene, represented $0.11 \%$ of the total peak area. Analyses for an impurity, 4-vinyl-1-cyclohexene, were also performed by gas chromatography (GC; $1 \mathrm{~m} \times 2 \mathrm{~mm}$ Porapak QS $80 / 100,150^{\circ} \mathrm{C}$ isothermal, FID). This impurity results from the thermally catalyzed dimerization of 1,3-butadiene, which occurs continuously during storage. Since the rate of "dimer" formation is temperature-dependent, care was taken to assure constant storage temperatures of approximately $72^{\circ} \mathrm{F}$. The dimer is considerably less volatile than 1,3-butadiene and therefore concentrates in the cylinder "heel" as the contents of the cylinder are exhausted. To prevent the appearance of high concentrations of dimer in the 1,3butadiene atmospheres used for the exposures, cylinder usage was limited to $80 \%$ of the net contents, and the acceptable dimer concentration in material sampled from the headspace was specified to be $<500 \mathrm{ppm}$. Prior to the study, the headspace dimer concentration of BNW 50846-36-2 was 332 ppm (Appendix A); periodic analyses performed during animal exposures yielded a mean headspace dimer concentration of $197 \pm 6 \mathrm{ppm}$ (Appendix A).

\section{B. INHALATION EXPOSURE SYSTEM}

The animals were exposed to the test atmospheres within stainless-steel chambers designed at BNW (U.S. Patent \#4,216,741; Brown and Moss, 1981; Moss et al., 1982) and fabricated by Hazelton Systems, Inc. (Aberdeen, MD). The total volume of the chamber was $2.3 \mathrm{~m}^{3}$, and the active mixing volume was $1.7 \mathrm{~m}^{3}$. There were three levels of caging in each chamber; each level was split into two tiers, which were offset from each other and from the chamber walls. Drawer-like stainlesssteel cage units, consisting of individual animal cages, were suspended in the space above each tier. Stainless-steel catch pans tor collection of urine and feces were positioned below each cage unit. Rats were exposed in individual cages (24/cage unit) equipped with feed troughs and automatic watering. During exposure, the feed troughs were removed from each cage unit. The chamber was designed so that uniform atmospheric concentrations of the test material could be maintained throughout the chamber when the catch pans were in position (Moss et al., 1982; Griffis et al., 1981).

Environmental conditions of the exposure chambers and the room were monitored throughout the study. These data included temperature, which was measured by means of thermistors, and relative humidity (RH), which was determined 
using an EG\&G Model 910 chilled-mirror dewpoint hygrometer. A multiplexed orifice meter system, in which calibrated flow orifices were installed at the inlet and exhaust outlet of each chamber, measured chamber air flow. A Validyne pressure transducer system was used to measure chamber air flow and chamber vacuum. Data for all environmental parameters are summarized in Appendix $B$.

All data-acquisition and automated system controls originated from an executive computer (Hewlett-Packard [HP] Model 9816), located in the Suite Control Center. Data from GC analyses were collected and preconditioned by an HP Model $85 \mathrm{~B}$ computer; data from all other monitoring equipment were interfaced through a Colorado Data Systems (CDS) Model 53A-IBX Intelligent Intertace System (IIS). Sy5tem control, by means of devices such as valves, drive motors, audible alarms, and indicator lamps, was provided from the computer by means of control relays in the CDS-IIS.

For generation of chamber atmospheres, 1,3-butadiene was withdrawn directly from the gas cylinder through a solenoid valve and, subsequently, through a check-valve filter-flow-limit switch and a flow meter, which accurately metered gas to a distribution manifold, where it was initially diluted with filtered air. An airdriven vacuum pump delivered the butadiene-air mixture to the exposure chamber inlet for final dilution to the desired concentration.

Chamber monitoring of 1,3-butadiene concentrations was performed using an HP 5840 gas chromatograph equipped with an FID, a Valco (1-ml loop) sampling valve and a Valco stream-select valve capable of sampling eight different sites. Both valves were mounted in the $\mathrm{GC}$ oven, which was maintained at $120^{\circ} \mathrm{C}$. The $1 / 8-\times 12-$ in. nickel column was packed with $1 \%$ SP-1000 on 60/80 mesh Carbopack B. The gas chromatograph was calibrated with volumetric standards prepared with calibrated syringes and gas-sampling bags. These calibrations were in good agreement with certified gas standards, the concentrations of which had been selected to bracket the range of exposure concentrations. Eight sites were sampled every 16 minutes: four exposure chambers, two "holding" chambers, the exposure room and the GC standard. Data from the monitor were accumulated by the HP 85B computer and compared with limit values for the specific sampling location. When the value exceeded the control limits, the HP 85B computer transmitted the information to the executive computer, which initiated an appropriate action to correct the con- 
centration. A summary of the 1,3-butadiene concentrations for each chamber during the 14-day exposure is shown in Table 1. Mean daily concentrations are listed in Appendix $B$.

TABLE 1. Summary of Exposure Chamber Atmospheric Concentrations of 1,3Butadiene During the Developmental Toxicology Study in the Rat

\begin{tabular}{|l|c|c|c|}
\hline \multirow{2}{*}{ Observation } & \multicolumn{3}{c|}{ Chamber Concentrations (ppm) } \\
\cline { 2 - 4 } & 40 & 200 & 1000 \\
\hline $\begin{array}{l}\text { Mean chamber concentration } \pm \text { standard } \\
\text { deviation (ppm) }\end{array}$ & $40.1 \pm 0.62$ & $199.8 \pm 2.61$ & $1005 \pm 11.9$ \\
\hline Range (ppm) & 42.6 to 31.1 & 212 to 165 & 1070 to 926 \\
\hline Relative standard deviation (\%) & 1.6 & 1.3 & 1.2 \\
\hline Mean of target concentrations (\%) & 100 & 100 & 101 \\
\hline
\end{tabular}

Periodic measurements of the chamber atmosphere for the dimer, 4-vinyl-1cyclohexene, were performed using an HP 5790 gas chromatograph equipped with an FID, a Valco sampling valve with a 5-ml loop and a column similar to that previously described for butadiene monitoring. Column temperature was programmed to $190^{\circ} \mathrm{C}$ at $30^{\circ} \mathrm{C} /$ minute, following an $0.5-$ minute hold at $120^{\circ} \mathrm{C}$. With this system, which employed a nitrogen carrier at $20 \mathrm{ml} /$ minute, 1,3-butadiene eluted at 0.33 minutes, and the dimer at 3.25 minutes. A $100 \mathrm{ppm}$ v/v certified standard of dimer in nitrogen was used to calibrate the gas chromatograph. Analyses for dimer concentrations in the atmosphere of the 1000-ppm chamber are shown in Table 2. These values were consistent with the analyses of dimer concentrations in the cylinder headspace and indicated that additional dimerization did not occur during generation of the test material.

Determinations of chamber characteristics were obtained in the presence and absence of animals. These included chamber balance measurements, which demonstrated the uniformity of chamber mixing (Appendix $\mathrm{C}$ ) and chamber buildup and decay information. These values were within $5 \%$ of the target concentrations of 1,3-butadiene or chamber evacuation ( $0 \mathrm{ppm}$ ) and were attained within 15 minutes, even when study animals were in the chamber (Figure 1). 
TABLE 2. 4-Vinyl-1-Cyclohexene (Dimer) Concentrations in the Atmosphere of the 1000-ppm 1,3-Butadiene Chamber of the Teratology Study with Rats

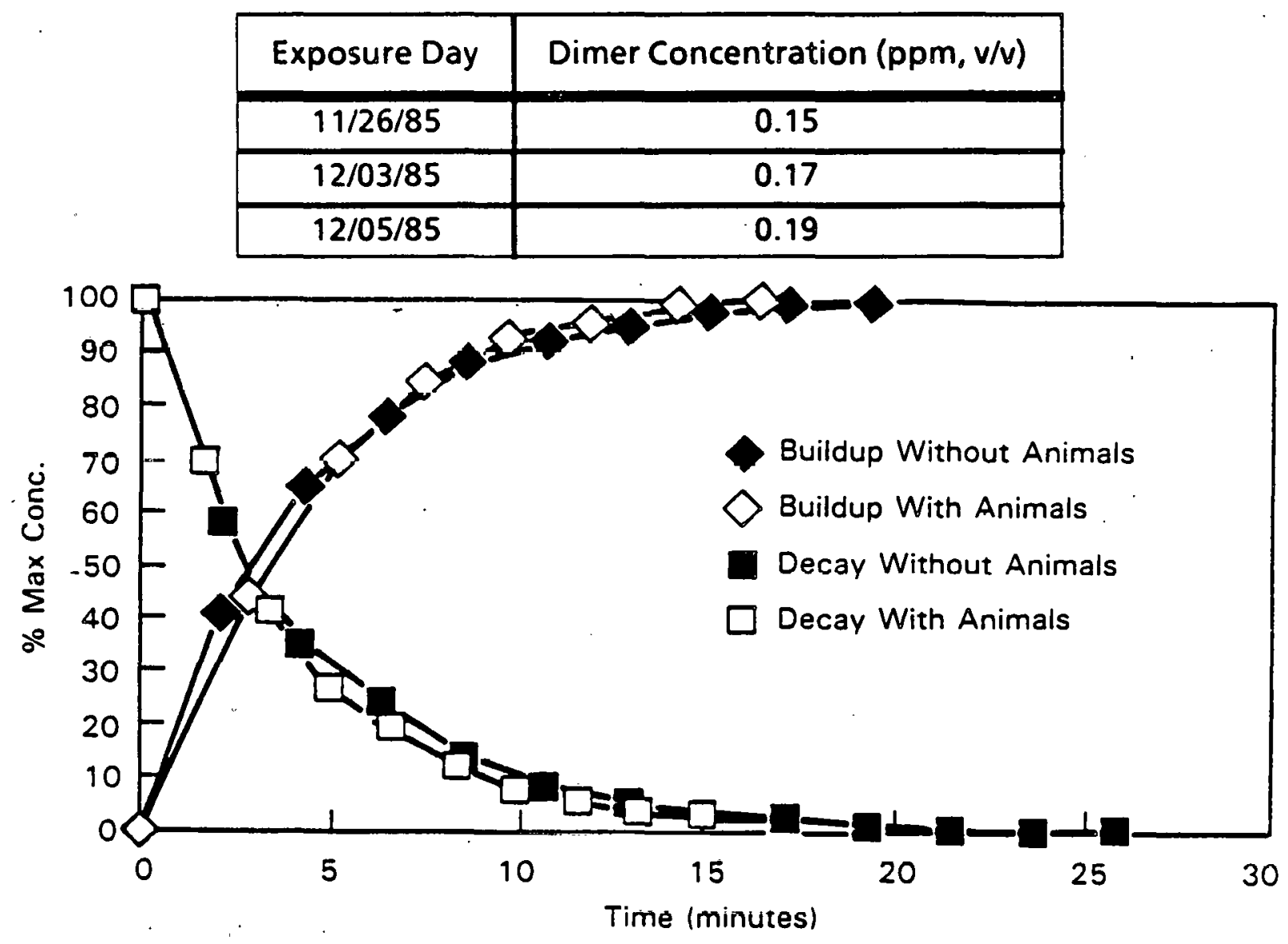

FIGURE 1. Buildup and Decay of the Atmosphere of the 1000-ppm 1,3-Butadiene Exposure Chamber in the Presence and Absence of Animals

\section{ANIMAL HUSBANDRY AND EXPOSURE PROCEDURES}

Salient features of the experimental design for this study are summarized in Table 3. For the study, 208 young-adult, Sprague-Dawley CD female $(7$ to 8 weeks old; 170 to $175 \mathrm{~g}$ ) and 108 male ( 7 to 8 weeks old; 200 to $225 \mathrm{~g}$ ) rats were purchased from Charles River Laboratory, Portage, MI Facility. The animals were isolated for 19 days, at which time five females and five males were killed and examined for internal and external parasites and bacterial pathogens; their sera were tested for antibodies to selected pathogens, and histopathologic examinations of lung, liver, kidney, ileum, colon, heart and Harderian gland were performed (Appendix D). At sac- 
rifice, serum from five females of the control group and five of the high dose group was tested for antibodies to selected pathogens; negative results were obtained.

TABLE 3. Experimental Design for Teratology Study of Rats Exposed to 1,3Butadiene

Chamber concentrations (ppm): $0,40,200$, and 1000

Number of sperm-positive females/exposure group: 30

Number of days of mating: 5 (resulting in five exposure subgroups)

Exposure regimen: 6 through 15 days of gestation (dg); 6 hours/day

Day of sacrifice: $20 \mathrm{dg}$

Maternal observations: Mortality and signs of toxicity; body weights on 0,6 , 11,16 and $20 \mathrm{dg}$; lesions at gross necropsy; weight of gravid uterus; number of implantation sites; intrauterine mortality; placental weights

Fetal observations: Body weight tabulated by sex; gross, visceral and skeletal examinations

Animal facilities and procedures at PNL were inspected and certified by the American Association of Laboratory Animal Care. During the isolation period, the animals were housed by sex, five rats per wire-mesh cage and provided (ad libitum) NIH-07 open formula diet; water was supplied by an automatic watering system. Temperatures and $\mathrm{RH}$ in the animal rooms were maintained in ranges of $72 \pm 3^{\circ} \mathrm{F}$ and $50 \pm 15 \%$, respectively.

Following the isolation period, the females were weighed and individually identified by numbered eartags. For mating, two females were caged overnight with one male. Mating continued for 5 successive nights to obtain the desired number of sperm-positive females. Copulation was established by a microscopic examination for sperm in a drop of normal saline delivered into, then recovered from, the vagina with a pipette. The morning of observation of sperm was designated as 0 dg. At this time, the sperm-positive females were weighed and assigned to exposure groups by means of a computer-assisted randomization program, which is based on a single blocking factor, body weight. In addition to individual eartag numbers, animals in each exposure group were identified by means of a distinctive toeclip on the forepaw. 
Three days prior to the initiation of exposure, the animals were housed in the exposure chambers in the exposure room. Environmental data were collected during this interval. Exposure to 1,3-butadiene atmospheres of 0 (filtered air), 40, 200 and $1000 \mathrm{ppm}$ commenced on $6 \mathrm{dg}$. Each animal was exposed to its assigned treatment daily for 6 hours/day from 6 through $15 \mathrm{dg}$. From $16 \mathrm{dg}$ until sacrifice at $20 \mathrm{dg}$. all animals were housed in exposure chambers with filtered-air atmospheres. The 5 days of mating resulted in staged starts and cessations of exposures. Accordingly, "filler" animals (excess males and females) were used to maintain a constant animal load in the exposure chambers. Water was provided ad libitum throughout the study; however, food was removed during the daily 6-hour exposure period.

\section{TOXICOLOGIC AND DEVELOPMENTAL OBSERVATIONS}

The animals were observed twice daily for mortality, morbidity and signs of toxicity. Female rats were weighed during the week prior to mating, and on $0,6,11$ and $16 \mathrm{dg}$. On $20 \mathrm{dg}$, the animals were euthanized with $\mathrm{CO}_{2}$, weighed, and examined for gross tissue abnormalities. The uterus was removed and weighed; apparently nongravid uteri were stained with ammonium sulfite to detect implantation sites (Kopf et al., 1964). The number, position and status of implants were recorded for gravid uteri; placentas were examined and weighed. Live fetuses were weighed, examined for gross defects, and their sex was determined. Because of the findings reported by Hazelton (1982), examinations for fetal lens opacities were conducted by removing the eyelid and examining the eye in situ. In addition, the eyeballs were removed for observation under the dissecting microscope. Visceral examinations (Staples, 1977) and skeletal examinations, using specimens stained with alcian blue and alizarin red (Kimmel and Trammell, 1981; Kimmel, personal communication), were performed on all live fetuses. Approximately $50 \%$ of the fetal heads were examined by razor-blade sectioning of fixed preparations (Wilson, 1965).

\section{E. STATISTICAL METHODS}

Analysis of variance (ANOVA; Steel and Torrie, 1980) was used to analyze weight data and, if the result of the analysis was significant, Duncan's multiplerange test (Duncan, 1955; Kramer, 1956) was used for further statistical analyses. Response proportions, such as the number of resorptions, implants, live, dead, or 
affected fetuses/litter, were also analyzed by ANOVA following arcsin transformation of the response proportion. An orthogonal contrast (Winer, 1971) was used to test trends for dose dependency. In the case of maternal weights, which were repeated over time, analyses for differences among growth curves employed a randomization test (Zerbe, 1979).

Binary-response variables between groups were compared, using chi-square or Fischer's exact test (Siegel, 1956). These variables included numbers of pregnant females/number inseminated. 


\section{RESULTS}

No deaths occurred in any of the four exposure groups during the study interval. No significant effects of treatment were observed for maternal body weight gains of rats exposed to 1,3-butadiene levels of 40 or 200 ppm, but weight gains of animals of the 1000-ppm group were significantly decreased for the period from 6 through $11 \mathrm{dg}$, the first 5 days of exposure (Table 4). Extragestational weight gains in the rats exposed to this highest concentration tended to be lower than values for control and 40-ppm groups and were significantly less than gains of animals exposed to $200 \mathrm{ppm}$ (Table 5). Weights of gravid uterı and values for extrayesldtional body weights for exposed animals were not significantly different from control values.

TABLE 4. Changes in Body Weights ( $g$, Mean \pm Standard Error) of Pregnant Rats Exposed to 1,3-Butadiene

\begin{tabular}{|c|c|c|c|c|}
\hline \multirow[b]{2}{*}{$\begin{array}{c}\text { Time Interval } \\
\text { (Day of Gestation) }\end{array}$} & \multicolumn{4}{|c|}{ 1,3-Butadiene Concentration (ppm) } \\
\hline & $\begin{array}{c}0 \\
(N=28) a\end{array}$ & $\left(\begin{array}{l}40 \\
(N)\end{array}\right.$ & $\left(N^{200}=26\right)$ & $\begin{array}{c}1000 \\
(N=28)\end{array}$ \\
\hline 0 to 6 & $21.4 \pm 1.6$ & $21.1 \pm 1.6$ & $22.9 \pm 1.3$ & $20.1 \pm 1.5$ \\
\hline 6 to 11 & $25.5 \pm 9.3^{b}$ & $23.6 \pm 1.3^{b}$ & $26.6 \pm 1.5 b$ & $17.5 \pm 1.9 c$ \\
\hline 11 to 16 & $29.2 \pm 1.4$ & $30.9 \pm 1.7$ & $31.7 \pm 1.9$ & $31.2 \pm 2.1$ \\
\hline 16 to 20 & $44.5 \pm 1.8$ & $36.7 \pm 2.5$ & $43.6 \pm 2.3$ & $43.2 \pm 2.9$ \\
\hline
\end{tabular}

aNumber of animals

$b, c$ Values that do not share a common letter are significantly different $(P \leqq 0.05)$ from one another.

The overall pregnancy rate among the rats of the study was $88 \%$ and ranged from $80 \%$ in those exposed to $40 \mathrm{ppm}$ to $93 \%$ in the 0 - and 1000 -ppm groups (Table 6). Differences in pregnancy rates among groups were not statistically significant. Numbers and percentages of implantations, resorptions and live or dead fetuses per litter were not affected by treatment. 
TABLE 5. Maternal Measures ( $g$, Mean \pm Standard Error) for Rats Exposed to 1,3Butadiene

\begin{tabular}{|l|c|c|c|c|}
\hline \multirow{2}{*}{ Observation } & \multicolumn{4}{|c|}{1,3 Butadiene Concentration (ppm) } \\
\cline { 2 - 5 } & 0 & 40 & 200 & 1000 \\
\hline $\begin{array}{l}\text { Body weight on 0 } \\
\text { day of gestation (dg) }\end{array}$ & $242 \pm 3.7$ & $239 \pm 3.2$ & $244 \pm 3.0$ & $242 \pm 4.0$ \\
\hline $\begin{array}{l}\text { Body weight on 20 } \\
\text { dg }\end{array}$ & $362 \pm 7.1$ & $351 \pm 5.9$ & $369 \pm 6.6$ & $354 \pm 6.1$ \\
\hline $\begin{array}{l}\text { Weight of gravid } \\
\text { uterus }\end{array}$ & $73.0 \pm 2.9$ & $69.5 \pm 3.5$ & $73.9 \pm 2.8$ & $71.2 \pm 4.1$ \\
\hline $\begin{array}{l}\text { Extragestational } \\
\text { weighta }\end{array}$ & $289 \pm 5.7$ & $282 \pm 3.9$ & $295 \pm 5.8$ & $283 \pm 5.7$ \\
\hline $\begin{array}{l}\text { Extragestational } \\
\text { weight gainb }\end{array}$ & $47.6 \pm 2.8$ & $42.7 \pm 2.2$ & $50.9 \pm 3.0$ & $39.9 \pm 3.5 \mathrm{c}$ \\
\hline
\end{tabular}

aExtragestational weight $=$ body weight on $20 \mathrm{dg}$ - weight of gravid uterus bExtragestational weight gain = extragestational weight - body weight on $0 \mathrm{dg}$ cSignificantly less than control at $P<0.05$

Exposure to 1,3-butadiene during development had no significant effect on fetal body weights, placental weights, or fetal sex ratios (Table 7). Individual data are presented in Appendix $E$.

One fetus in each of three litters in the 40-ppm exposure group was hydrocephalic. Two fetuses from one litter in the 1000-ppm group each had a meningoencephalocele; in addition, one of these fetuses also had microphthalmia accompanied by aphakia and retinal dysgenesis. Another litter in the 1000-ppm group had one fetus with a dilation between the meninges and the skull. No major malformations of the head were found in fetuses from the control or the 200-ppm exposure groups. No significant treatment-related differences or trends were noted in the incidence of malformations (Table 8; Appendix F).

The incidence of reduced ossification of sternebrae numbers 1 through 4 was higher in fetuses of the 200-ppm treatment group than in control fetuses, but values for fetuses from the 40- and 1000-ppm groups were not different from control values (Table 9; Appendix F). In contrast, the number of fetuses with 
TABLE 6. Reproductive Measures (Mean \pm Standard Error) for Rats Exposed to 1,3Butadiene

\begin{tabular}{|c|c|c|c|c|}
\hline \multirow[b]{2}{*}{ Observation } & \multicolumn{4}{|c|}{ 1,3 Butadiene Concentration (ppm) } \\
\hline & 0 & 40 & 200 & 1000 \\
\hline $\begin{array}{l}\text { Number of: } \\
\text { Rats exposed } \\
\text { Pregnant rats (\%) } \\
\text { Litters with live fetuses } \\
\text { Implantations/dam } \\
\text { Resorptions/litter } \\
\text { Early } \\
\text { Late } \\
\text { Dead fetuses/litter } \\
\text { Live fetuses/litter }\end{array}$ & $\begin{array}{c}30 \\
28(93) \\
28 \\
14.4 \pm 0.55 \\
0.46 \pm 0.17 \\
0.39 \pm 0.15 \\
0.07 \pm 0.05 \\
0 \\
13.9 \pm 0.56\end{array}$ & $\begin{array}{c}30 \\
24(80) \\
24 \\
14.0 \pm 0.71 \\
0.58 \pm 0.17 \\
0.54 \pm 0.16 \\
0.04 \pm 0.04 \\
13.4 \pm 0.66\end{array}$ & $\begin{array}{c}30 \\
26(87) \\
26 \\
15.3 \pm 0.45 \\
0.96 \pm 0.26 \\
0.88 \pm 0.25 \\
0.08 \pm 0.08 \\
14.3 \pm 0.52\end{array}$ & $\begin{array}{c}30 \\
28(93) \\
27 a \\
14.8 \pm 0.63 \\
0.67 \pm 0.14 \\
0.63 \pm 0.14 \\
0.04 \pm 0.04 \\
14.2 \pm 0.60\end{array}$ \\
\hline $\begin{array}{l}\text { Percentage of: } \\
\text { Resorptions/litter } \\
\text { Early } \\
\text { Late } \\
\text { Live fetuses/litter }\end{array}$ & $\begin{array}{l}3.24 \pm 1.20 \\
2.79 \pm 1.12 \\
0.45 \pm 0.31 \\
96.8 \pm 1.20\end{array}$ & $\begin{array}{l}3.80 \pm 1.05 \\
3.50 \pm 0.96 \\
0.30 \pm 0.30 \\
96.2 \pm 1.05\end{array}$ & $\begin{array}{l}6.37 \pm 1.86 \\
5.85 \pm 1.78 \\
0.51 \pm 0.51 \\
93.6 \pm 1.86\end{array}$ & $\begin{array}{l}4.29 \pm 0.86 \\
4.06 \pm 0.87 \\
0.23 \pm 0.22 \\
95.7 \pm 0.86\end{array}$ \\
\hline
\end{tabular}

astatistical analyses were perfromed after dam \#94 was excluded from the 1000ppm group. This dam, which had only one implant, was considered to be an outlier and not representative of the population. The following numbers were obtained when results from this dam remained in the data set: Implantations/dam, $14.4 \pm 0.78$; Resorptions/litter, $0.68 \pm 0.14$; Early/litter, $0.64 \pm 0.14$; Live fetuses/litter, $13.7 \pm 0.77$; Percentage of resorptions/litter, $7.71 \pm 3.52$; Early, $7.49 \pm 3.53 ;$ and Live fetuses/litter, $92.3 \pm 3.52$.

TABLE 7. Fetal and Placental Measures (Mean \pm Standard Error) for Rat Litters Exposed to 1,3-Butadiene

\begin{tabular}{|l|c|c|c|c|}
\hline \multirow{2}{*}{\multicolumn{1}{|c|}{ Observation }} & \multicolumn{4}{|c|}{1,3 Butadiene Concentration (ppm) } \\
\cline { 2 - 5 } & 0 & 40 & 200 & 1000 \\
\hline $\begin{array}{l}\text { Number of: } \\
\text { Litters examined } \\
\text { Fetuses examined }\end{array}$ & 28 & 24 & 26 & 27 \\
\hline $\begin{array}{l}\text { Body weight (g) } \\
\text { Females } \\
\text { Males }\end{array}$ & $3.49 \pm 0.04$ & $3.44 \pm 0.05$ & $3.40 \pm 0.05$ & $3.50 \pm 0.06$ \\
\hline Sex ratio (\% males) & $3.40 \pm 0.05$ & $3.36 \pm 0.05$ & $3.29 \pm 0.05$ & $3.38 \pm 0.06$ \\
\hline Placental weight (mg) & $50.2 \pm 2.28$ & $52.5 \pm 2.95$ & $50.5 \pm 2.77$ & $52.5 \pm 2.58$ \\
\hline $\begin{array}{l}\text { Females } \\
\text { Males }\end{array}$ & $429 \pm 9.0$ & $423 \pm 9.6$ & $437 \pm 12.4$ & $421 \pm 9.3$ \\
& $421 \pm 9.3$ & $414 \pm 9.8$ & $431 \pm 13.4$ & $414 \pm 10.3$ \\
\hline
\end{tabular}


reduced ossification of thoracic vertebrae in the 200- and in the $1000-\mathrm{ppm}$ groups was significantly lower than the number with this variation in the control group. When reduced ossifications at all anatomical sites were combined and the incidences compared on a litter basis, there were no effect of treatment on the mean percent of litters affected (Table 10).

TABLE 8. Malformations in Fetuses of Rats Exposed to 1,3-Butadienea

\begin{tabular}{|c|c|c|c|c|}
\hline \multirow[b]{2}{*}{ Observation } & \multicolumn{4}{|c|}{ 1,3 Butadiene Concentration (ppm) } \\
\hline & 0 & 40 & 200 & 1000 \\
\hline $\begin{array}{l}\text { Number Examined } \\
\text { Litters } \\
\text { Fetuses } \\
\text { Fetal heads }\end{array}$ & $\begin{array}{r}28 \\
389 \\
196\end{array}$ & $\begin{array}{r}24 \\
321 \\
161\end{array}$ & $\begin{array}{r}26 \\
372 \\
185\end{array}$ & $\begin{array}{r}27 \\
382 \\
191\end{array}$ \\
\hline $\begin{array}{l}\text { Malformations } \\
\text { Generalized edema } \\
\text { Hydrocephalus } \\
\text { Meningoencephalocele } \\
\text { Dilatation between meninges and skull } \\
\text { Aphakia/retinal dysgenesis } \\
\text { Microphthalmia } \\
\text { Retroesophageal right subclavian artery } \\
\text { Aortic stenosis } \\
\text { Undescended testes } \\
\text { Fused sternebrae } \\
\text { Missing ribs } \\
\text { Bent tibia }\end{array}$ & \begin{tabular}{c}
$1 / 1$ \\
--- \\
--- \\
--- \\
\hdashline- \\
$1 / 1$ \\
--- \\
-- \\
-- \\
---
\end{tabular} & $\begin{array}{l}3 / 1 \\
3 / 3 \\
--- \\
--- \\
-- \\
--- \\
--- \\
--- \\
-- \\
--\end{array}$ & $\begin{array}{c}1 / 1 \mathrm{~b} \\
--- \\
--- \\
--- \\
--- \\
--- \\
1 / 1 \mathrm{~b} \\
1 / 1 \mathrm{~b} \\
1 / 1 \\
2 / 2 \mathrm{~d} \\
1 / 1 \mathrm{~b}\end{array}$ & $\begin{array}{c}3 / 1 c \\
--2 \\
2 / 1 c \\
1 / 1 \\
1 / 1 c \\
1 / 1 c \\
-- \\
--- \\
-- \\
-- \\
--\end{array}$ \\
\hline TOTAL MALFORMED & $2 / 2$ & $6 / 4$ & $3 / 3$ & $4 / 2$ \\
\hline
\end{tabular}

aExpressed as number of fetuses/number of litters

bFetus \#6 in litter \# 187

cLitter \# 188: fetus \#9, edema, meningoencephalocele; \#14, edema, meningoencephalocele, aphakia/retinal dysgenesis; \# 16, edema, microphthalmia dincludes fetus \#6 in litter \# 187

Lens opacities were not observed when fetal eye examinations were conducted in situ immediately after death. It was noted, however, that lens opacities could be detected in fetuses from both exposed and control groups when the examination was delayed, or when the eye was removed prior to examination. When water or saline was added to the eyes during examination, the lens no longer appeared opaque. Although a formal study of this phenomenon was not con- 
TABLE 9. Fetal Variationsa in Rats Exposed to 1,3-Butadiene

\begin{tabular}{|c|c|c|c|c|}
\hline \multirow[b]{2}{*}{ Observation } & \multicolumn{4}{|c|}{ 1,3 Butadiene Concentration (ppm) } \\
\hline & 0 & 40 & 200 & 1000 \\
\hline $\begin{array}{l}\text { Number Examined } \\
\text { Litters } \\
\text { Fetuses } \\
\text { Fetal heads }\end{array}$ & $\begin{array}{r}28 \\
389 \\
196\end{array}$ & $\begin{array}{r}24 \\
321 \\
161\end{array}$ & $\begin{array}{r}26 \\
372 \\
185\end{array}$ & $\begin{array}{r}27 \\
382 \\
191\end{array}$ \\
\hline $\begin{array}{l}\text { Variations } \\
\text { Pale } \\
\text { Low ear set } \\
\text { Missing innominate artery } \\
\text { Hydroureter } \\
\text { Misaligned sternebrae } \\
\text { Extra ribs }\end{array}$ & $\begin{array}{c}1 / 1 \\
-- \\
-- \\
36 / 17 \\
\cdots \\
\cdots\end{array}$ & $\begin{array}{c}\cdots \\
\cdots-- \\
\cdots 3 / 15 \\
-- \\
1 / 1\end{array}$ & $\begin{array}{l}--- \\
1 / 1 c \\
2 / 1 \\
39 / 14 \\
1 / 1 \\
4 / 2\end{array}$ & $\begin{array}{c}--- \\
--- \\
31 / 12 \\
1 / 1\end{array}$ \\
\hline $\begin{array}{l}\text { Reduced Ossification } \\
\text { Skull } \\
\text { Sternebrae } \\
\quad \# 1-4 \\
\text { Ribs } \\
\text { Vertebrae (Centra) } \\
\quad \text { Thoracic } \\
\quad \text { Lumbar } \\
\text { Pelvis } \\
\text { Phalanges } \\
\text { Tibia } \\
\text { Fibula }\end{array}$ & $\begin{array}{c}27 / 13 \\
60 / 15 \\
1 / 1 \\
109 / 23 \\
-\cdots \\
9 / 7 \\
1 / 1 \\
\cdots--\end{array}$ & $\begin{array}{c}22 / 13 \\
48 / 13 \\
2 / 2 \\
97 / 21 \\
-- \\
-- \\
6 / 1 \\
-- \\
--\end{array}$ & $\begin{array}{c}18 / 10 \\
95 / 21 \\
5 / 3 \\
75 / 20 \\
1 / 1 \mathrm{~b} \\
6 / 5 \\
2 / 1 \\
1 / 1 \mathrm{~b} \\
1 / 1 \mathrm{~b}\end{array}$ & $\begin{array}{c}29 / 11 \\
66 / 15 \\
2 / 2 \\
81 / 25 \\
-- \\
5 / 5 \\
--- \\
---\end{array}$ \\
\hline
\end{tabular}

aExpressed as number of fetuses/number of litters bfetus \#13 in litter \#92

TABLE 10. Mean Percent of Reduced Ossification or Hydroureter per Litter Following Exposure to 1,3-Butadiene (Mean I Standard Deviation)

\begin{tabular}{|l|c|c|c|c|}
\hline \multirow{2}{*}{ Observation } & \multicolumn{4}{|c|}{1,3 Butadiene Exposure Concentration (ppm) } \\
\cline { 2 - 5 } & $0 \%$ & $40 \%$ & $200 \%$ & $1000 \%$ \\
\hline Reduced ossification & $41 \pm 27 \mathrm{a}$ & $48 \pm 24$ & $45 \pm 28$ & $43 \pm 29$ \\
\hline Hydroureter & $9 \pm 11$ & $14 \pm 22$ & $10 \pm 16$ & $8 \pm 13$ \\
\hline
\end{tabular}

aMean percent \pm standard deviation of the litter affected 
ducted, these results suggest that the opacities were artifactual, most probably resulting from postmortem dehydration of the fetal eye. 


\section{DISCUSSION}

In this study, no significant effects on maternal body weight gains were found in rats exposed to concentrations of 1,3-butadiene as high as $200 \mathrm{ppm}$. Body weight gains of animals exposed to $1000 \mathrm{ppm}$ were significantly decreased during the first 5 days of exposure. Extragestational gains in these rats were also depressed, although they were not significantly lower than those of the control animals. Results from the Hazelton study (1982) showed that a significant depression in body weight gains occurred in rats during exposure to 200 and $1000 \mathrm{ppm}$ and that a significant decrease in adjusted body weight gain from 0 to $20 \mathrm{dg}$ (analogous to extragestational weight gain) was evident in the rats exposed to $1000 \mathrm{ppm}$. Although the findings in this study and the Hazelton sludy are not in complctc agreement, the overall results show that higher concentrations ( $\geqq 1000 \mathrm{ppm}$ ) of 1,3-butadiene have a detectable effect on various measures of maternal weight gain. However, our results from exposure to $200 \mathrm{ppm}$ were not consistent with the Hazelton study which indicated that weight gains, depressed during exposure, recovered to control values by the time the animals were sacrificed. Our study showed that the lower concentrations, 40 and 200 ppm, did not have detectable effects on various measures of weight gain, nor did they produce clinical signs of toxicity, suggesting that these concentrations were not maternally toxic.

None of the reproductive indices (e.g., number of litters with live fetuses, number of live fetuses per litter, number of resorptions per litter) were significantly affected by exposure to 1,3-butadiene vapors during gestation. Although the percentages of early resorptions per litter for all butadiene exposure groups were slightly elevated above controls, these differences were not statistically significant. Results from the Hazelton study (1982) also indicated that postimplantation losses, primarily early resorptions, were slightly, but not significantly, higher in all butadiene-exposed groups (200, 1000 and 8000 ppm).

For interpretation of the results of examinations for fetal variations, such as those obtained for reduced ossification, it is considered more appropriate to use the litter, rather than the fetus, as the experimental unit (Kalter, 1974; Haseman and Hogan, 1975). Moreover, irregular rates of osssification, particularly in fetal vertebrae and sternebrae, is a common observation in stocks of animals that have been 
used in this laboratory as well as in other laboratories. Previous studies (Aliverti et al., 1979) have demonstrated that there are within-litter variations in skeletal ossification at $20 \mathrm{dg}$, a result that would tend to indicate that the use of the litter as the experimental unit would provide the most conservative interpretation. The foregoing considerations, together with our inability to correlate these findings with reductions in fetal body weight or exposure level, strongly indicate that these changes are not biologically significant. Under the conditions of this exposure regimen, there was no evidence for a teratogenic response to 1,3-butadiene exposure.

All facets of these studies were conducted in compliance with the Food and Drug Administration's Good Laboratory Practices, 21 CFR 58. During the performance of these studies, no problems were encountered that we consider would affect the integrity of the results. 


\section{REFERENCES}

Aliverti, V., L. Bonanomi, E. Giavini, V. G. Leone, and L. Mariani. 1979. The extent of fetal ossification as an index of delayed development in teratogenic studies on the rat. Teratology 20: 237-242.

Battelle, Pacific Northwest Laboratories; Battelle-Northwest (BNW). 1984. Toxico/ogy and Carcinogenesis Studies of 1,3-Butadiene (CAS No. 106-00-0) in B6C3F. Mice (Inhalation Studies), National Toxicology Program Technical Report Series No. 288, August, NIH Publication No. 84-2544. National Institutes of Health, Washington, DC.

Brown, M. G. and O. R. Moss. 1981. An inhalation exposure chamber designed for animal handling. Lab. Anim. Sci. 31: 717-720.

Carpenter, C. P., C. B. Shaffer, C. S. Weil, and H. F. Smyth, Jr. 1944. Studies on the inhalation of 1,3-butadiene; with a comparison of its narcotic effect with benzol, toluol, and styrene, and a note on the elimination of styrene by the human. J. Ind. Hyq. Toxicol. 26: 69-78.

Duncan, D. B. 1955. Multiple range and multiple $F$ tests. Biometrics 11: 1-42.

Erley, D. S. and B. H. Blake. Infrared spectra of gases and vapors, Part No. 001-3994. In: Grating Spectra, Volume II. The Dow Chemical Company, Midland, MI.

Griffis, L. C., R. K. Wolfe, R. L. Beethe, C. H. Hobbs, and R. O. McClellan. 1981. Evaluation of a multitiered inhalation exposure chamber. Fundam. Appl. Toxicol. 1: 8-12.

Haseman, J. K. and M. D. Hogan. 1975. Selection of the experimental unit in teratology studies. Teratology 12: 165-172.

Hazelton Laboratories, Europe, Ltd. 1981. The Toxicity and Carcinogenicity of Butadiene Gas Administered to Rats by Inhalation for Approximately 24 Months, Report No: 2653-522/2. International Institute of Synthetic Rubber Producers. 
Hazelton Laboratories, Europe, Ltd. 1982. 1,3-Butadiene: Inhalation Teratogenicity Study in the Rat, Report No. 2653-522/2; HSE-81-0040/3, November 1; HSE-810040, Addendum 1, March 1982. International Institute of Synthetic Rubber Producers.

Kalter, H. 1974. Choice of the number of sampling units in teratology. Teratology 9: 257-258.

Kimmel, C. A. and G. Trammell. 1981. A rapid procedure for routine double staining of cartilage and bone in fetal and adult animals. Stain Technol. 56: 271-273.

Kopf, R., D. Lorenz, and E. Salewski. 1964. Der Einfluss von Thalidomid auf die Fertilität van Ratten in Generations versuch über Zwei Generationen. NaunynSchmiedebergs Arch. Exp. Pathol. Pharmacol 247: 127-135.

Kramer, C. Y. 1956. Extension of multiple range tests to group means with unequal numbers of replications. Biometrics 12: 307-310.

Moss, O. R., J. R. Decker, and W. C. Cannon. 1982. Aerosol mixing in an animal exposure chamber having three levels of caging with excreta pans. Am. Ind. Hyq. Assoc. J. 43: 244-249.

National Institute of Occupational Safety and Health (NIOSH). 1980. Projected Number of Occupational Exposures to Chemical and Physical Hazards. NIOSH, Cincinnati, $\mathrm{OH}$.

Siegel, S. 1956. Non-Parametric Statistics for the Behavioral Sciences. McGraw-Hill, New York, NY.

SRI International. 1979. Chemical Economics Handbook. SRI International, Menlo Park, CA.

SRI International. 1981. Chemical Hazard Information Profile, 1,3-Butadiene, CAS No. 106-99-0, Draft Report. SRI International, Menlo Park, CA. 
Staples, R. E. 1977. Detection of visceral alterations in mammalian fetuses. Teratology 9: A37-A38.

Steel, R. D. G. and J. H. Torrie. 1980. Principles and Procedures of Statistics. McGraw-Hill, New York, NY.

Wilson, J. G. 1965. Methods for administering agents and detecting malformations in experimental animals, pp. 262-277. In: Teratology Principles and Techniques, J. G. Wilson and J. Warkany (eds.). University of Chicago Press, Chicago, IL.

Winer, B. J. 1971. Statistical Principles in Experimental Design. McGraw-Hill, New York, NY.

Zerbe, G. O. 1979. Randomization analysis of a completely randomized design extended to growth and response curves. J. Am. Stat. Assoc. 79: 215-221. 
APPENDIXA

ANALYTICAL DATA FOR 1,3-BUTADIENE (LOT NUMBER F909)

IJM-482A 


\section{BULK CHEMICAL REANALYSIS FOR 1,3-BUTADIENE}

Compound:

NTP number:

CAS number:

Lot:

Appearance:

Receipt date:

Analysis period:

Storage temperature:

Sample submittal date:

Sample analysis date:

Analysis procedure:

Notebook reference:

Assay:

Results:

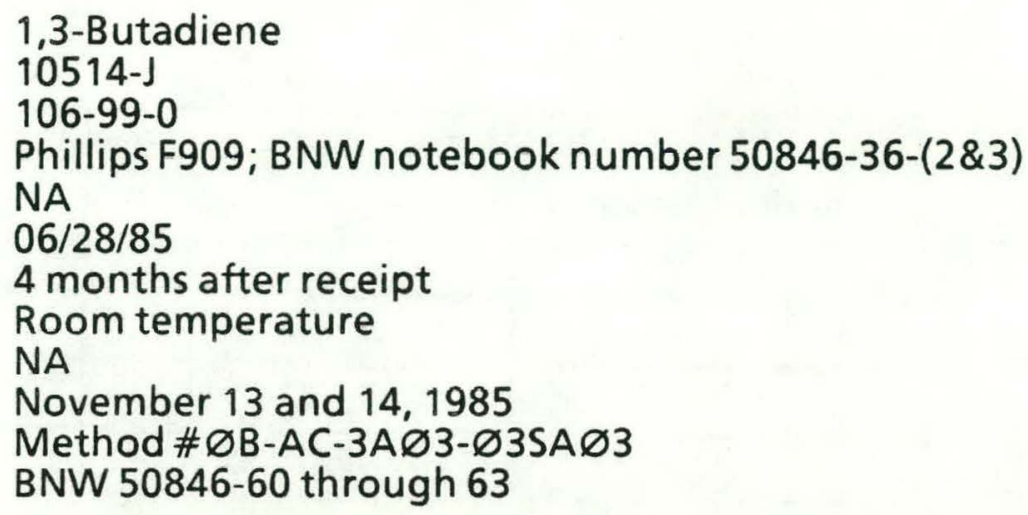

Phillips F909; BNW notebook number 50846-36-(2\&3)

NA

$06 / 28 / 85$

4 months after receipt

Room temperature

NA

November 13 and 14,1985

Method \#ØB-AC-3АØЗ-Ø3SAØ3

BNW 50846-60 through 63

Gas chromatography, using a 2-m $\times 2$-mm glass column packed with Porapak QS 100/120 for purity by area percent and 1-m x 2-mm glass column packed with Porapak PS $80 / 100$ for the dimer analysis, dimer content is determined from the ratio of the area of the dimer peak versus the area of the 1,3-butadiene peak. Instrument: Hewlett-Packard 5840A

\begin{tabular}{|c|c|c|}
\hline Date & Sample ID & Bulk \\
\hline $11 / 85$ & BNW 50846-36-2 & 99.88 \\
\hline
\end{tabular}

1,3-Butadiene eluted at $\sim 6.7$ minutes. A minor peak eluted 2 minutes later; it represented $0.11 \%$ of the total peak area.

\begin{tabular}{|c|c|c|}
\hline Date & Sample ID & $\begin{array}{c}\text { Dimer } \\
(\mathrm{ppm})\end{array}$ \\
\hline $11 / 85$ & BNW 50846-36-2 & $332 \mathrm{a}$ \\
\hline
\end{tabular}

1,3-Butadiene eluted at $\sim 0.4$ minutes, the dimer at $\sim 4.7$ minutes. The dimer retention time was confirmed by running a dimer standard.

aDifferences in values for dimer concentrations in individual cylinders reflect the thermal and usage history of each cylinder (see p. 5 of report). 
HEADSPACE DIMER CONTENT OF THE 1,3-BUTADIENE CYLINDER DURING RAT EXPOSURES

\begin{tabular}{|c|c|c|}
\hline $\begin{array}{c}\text { Cylinder Number } \\
\text { BNW 50846-36- }\end{array}$ & Date & $\begin{array}{c}\text { Dimer } \\
\text { Concentration } \\
(\mathrm{ppm} \text { v/v) }\end{array}$ \\
\hline 2 & $11 / 26 / 85$ & 190 \\
\hline 2 & $12 / 02 / 85$ & 200 \\
\hline 2 & $12 / 06 / 85$ & 202 \\
\hline
\end{tabular}


Punty Analysio of 13 -butadian Lor BNw $50846-36-2+3$. BNW $50846-60 \rightarrow 63 \quad M \cdot M \cdot$ Culloch $G C=H P 5840$ WA 10706 Column: $2 m m \times 6$ fr, glass packed $=$ Porapat QS $100 / 120$.

BNU50846-36-2 1,3-butadiene sod injt3

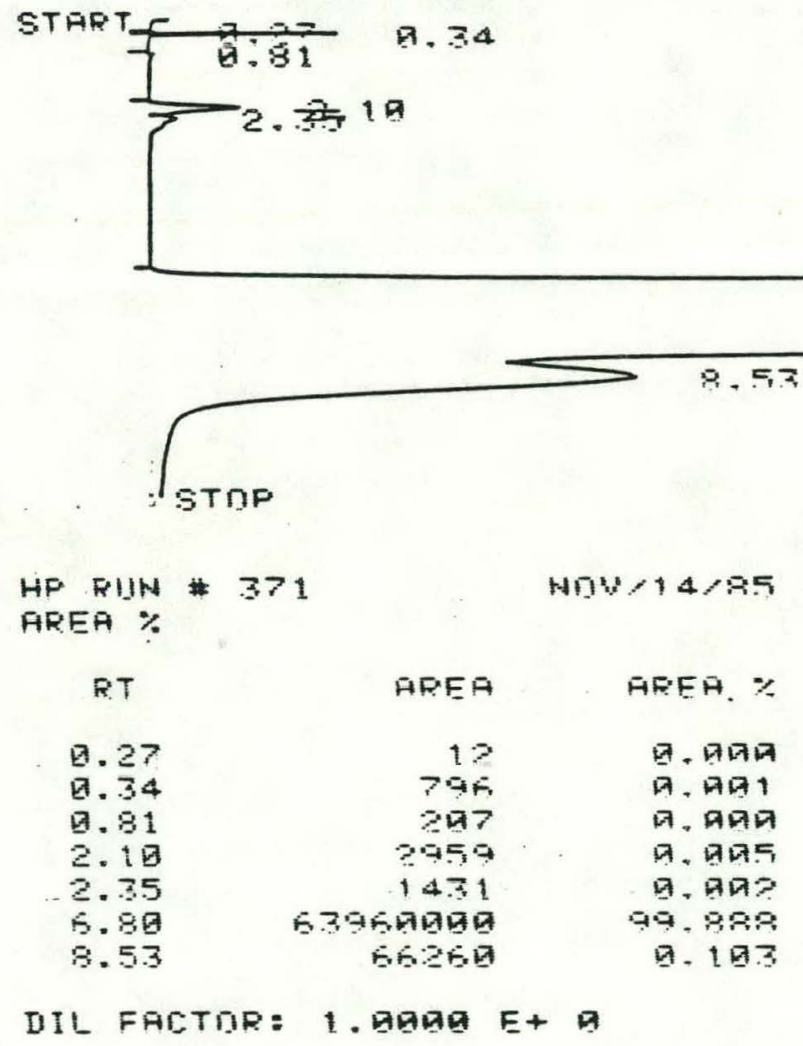

0.27

…34

ㅁ. 81

2.18

2.35

6.86

8.53

AFEA. $\%$

DIL FAFTHR: 1. BQRA E+ M 
Dimer Analysis of 1,3-biradiane

Lor BNin 52546-36-2+3.

BNu $50846-60 \rightarrow 63$

$m \cdot m$ Ciellod 1113185

Ge HP5840 WAF10706

Column: 2inmx 3fr glass paeked épreat PS
$80 / 100$

Ing 141,3 butediene kNW SC84L-3t-2 $0.2 m$

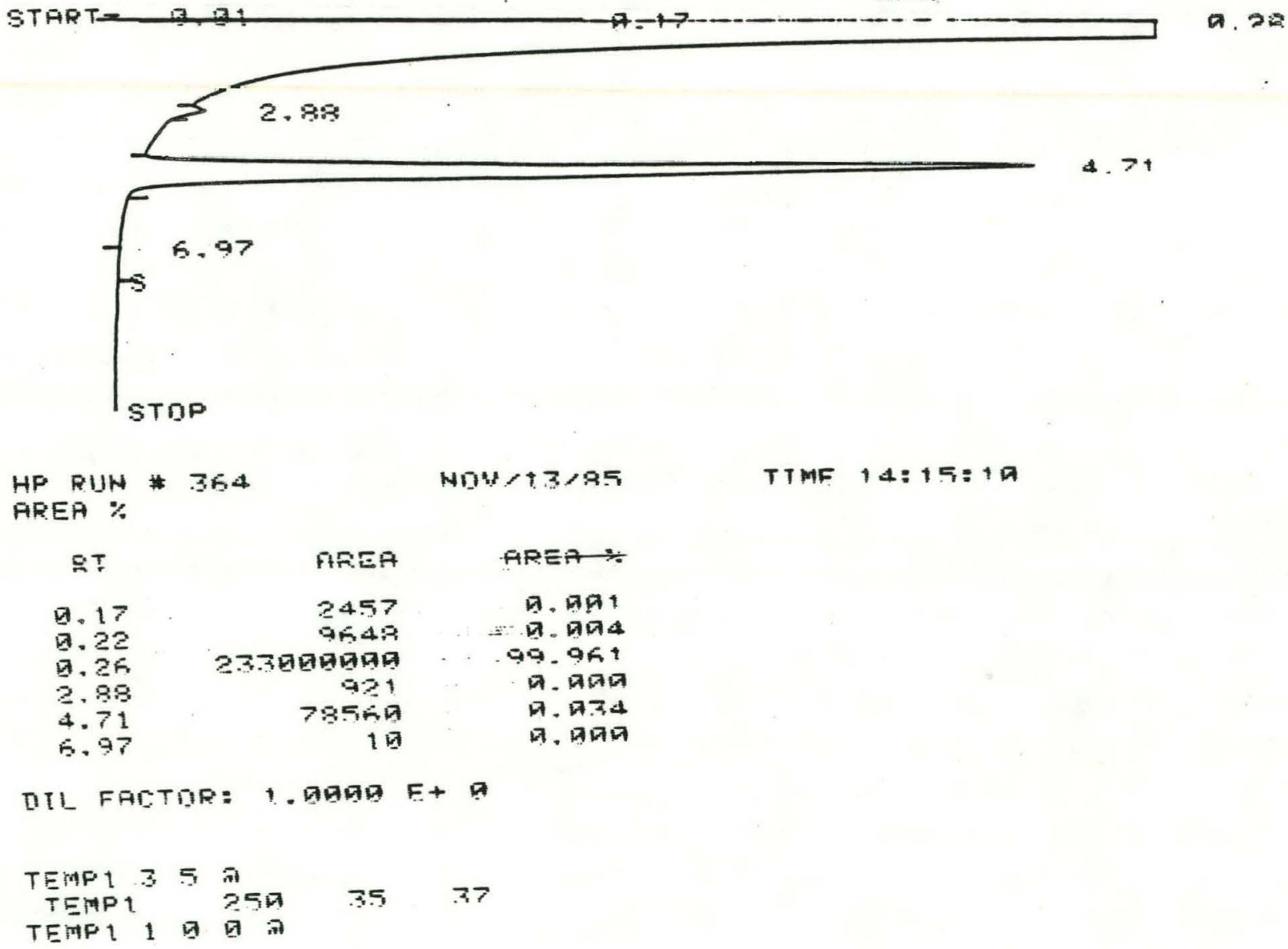

FIGURE A2. Gas Chromatogram of 1,3-Butadiene Dimer 


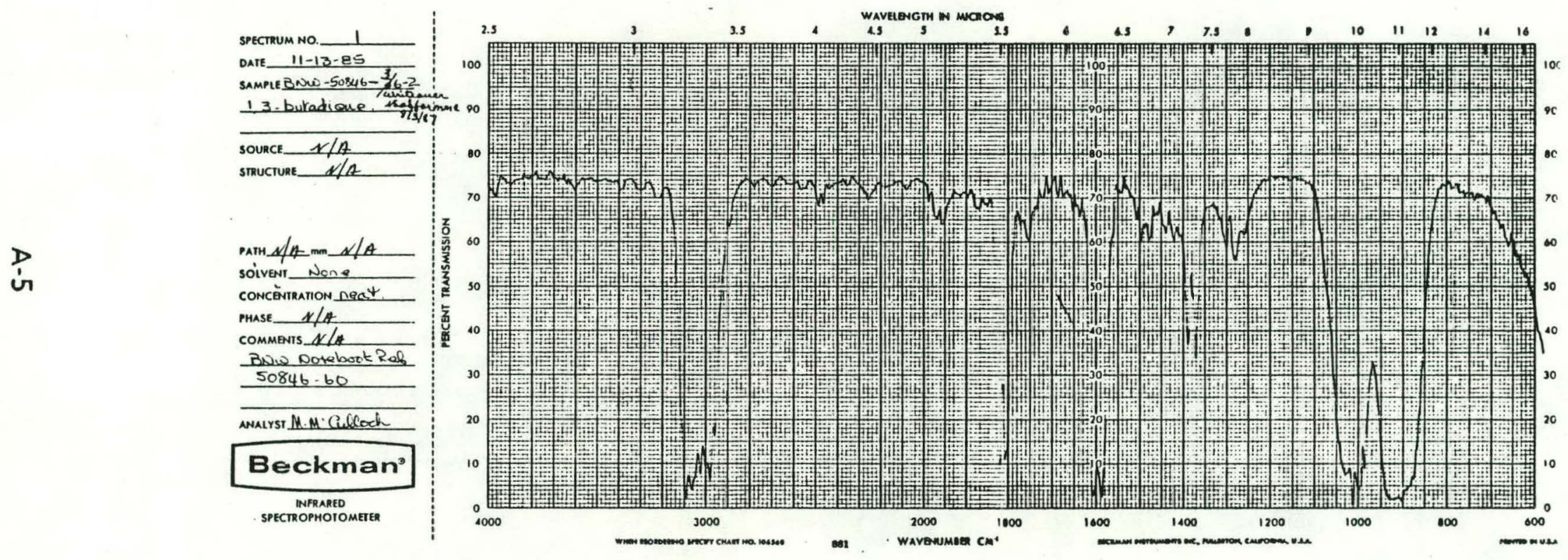

FIGURE A3. Infrared Spectrum of 1,3-Butadiene (Beckman Acculab 8, 10-cm Gas Cell) 


\section{APPENDIX B}

BUTADIENE CONCENTRATIONS, TEMPERATURE, AND RELATIVE HUMIDITY MEASUREMENTS IN THE EXPOSURE CHAMBERS 
TABLE B1. Exposure Chamber Atmospheric Concentrations (Mean Daily Concentration \pm Standard Deviation) of 1,3-Butadiene During the Teratology Study in Rats

\begin{tabular}{|c|c|c|c|}
\hline \multirow{2}{*}{$\begin{array}{c}\text { Exposure } \\
\text { Day }\end{array}$} & \multicolumn{3}{|c|}{ Chamber Concentrations (ppm) } \\
\cline { 2 - 4 } & 40 & 200 & 1000 \\
\hline $11 / 25 / 85$ & $38.5 \pm 0.55$ & $195 \pm 3.94$ & $981 \pm 18.8$ \\
\hline $11 / 26 / 85$ & $40.0 \pm 0.15$ & $199 \pm 1.55$ & $1010 \pm 6.39$ \\
\hline $11 / 27 / 85$ & $40.2 \pm 0.59$ & $199 \pm 4.89$ & $1000 \pm 19.2$ \\
\hline $11 / 28 / 85$ & $40.7 \pm 0.70$ & $205 \pm 2.72$ & $1030 \pm 12.0$ \\
\hline $11 / 29 / 85$ & $40.2 \pm 0.42$ & $201 \pm 1.31$ & $1010 \pm 7.77$ \\
\hline $11 / 30 / 85$ & $40.5 \pm 0.29$ & $200 \pm 1.44$ & $1000 \pm 7.31$ \\
\hline $12 / 01 / 85$ & $40.3 \pm 0.42$ & $201 \pm 1.58$ & $1000 \pm 9.52$ \\
\hline $12 / 02 / 85$ & $40.3 \pm 0.80$ & $202 \pm 3.92$ & $1010 \pm 27.6$ \\
\hline $12 / 03 / 85$ & $38.9 \pm 2.70 a$ & $195 \pm 9.63$ & $992 \pm 17.8$ \\
\hline $12 / 04 / 85$ & $40.3 \pm 0.34$ & $200 \pm 1.70$ & $1000 \pm 8.40$ \\
\hline $12 / 05 / 85$ & $40.4 \pm 0.61$ & $200 \pm 1.84$ & $1000 \pm 7.48$ \\
\hline $12 / 06 / 85$ & $40.6 \pm 0.71$ & $202 \pm 3.30$ & $1020 \pm 15.0$ \\
\hline $12 / 07 / 85$ & $40.0 \pm 0.75$ & $199 \pm 3.19$ & $1010 \pm 23.8$ \\
\hline $12 / 08 / 85$ & $40.0 \pm 0.61$ & $199 \pm 2.66$ & $1010 \pm 8.80$ \\
\hline
\end{tabular}

aThe computer terminated the exposure prematurely (cause unknown). Only one individual chamber concentration measurement (31.11 ppm) was less than the lower critical operating limit of $32 \mathrm{ppm}$ 
TABLE B2. Exposure Chamber Temperatures ( ${ }^{\circ} \mathrm{F}$, Daily Mean \pm Standard Deviation) for the Teratology Study of 1,3-Butadiene in Rats

\begin{tabular}{|c|c|c|c|c|}
\hline \multirow{2}{*}{$\begin{array}{c}\text { Exposure } \\
\text { Day }\end{array}$} & \multicolumn{4}{|c|}{ Exposure Chamber (ppm) } \\
\hline & 0 & 40 & 200 & 1000 \\
\hline $11 / 22 / 85$ & $71.0 \pm 0.51 a$ & $71.8 \pm 0.27 a$ & $72.0 \pm 0.34$ & $72.0 \pm 0.21$ \\
\hline $11 / 23 / 85$ & $70.9 \pm 0.24 a$ & $72.0 \pm 0.36$ & $72.3 \pm 0.35$ & $72.2 \pm 0.28$ \\
\hline $11 / 24 / 85$ & $71.2 \pm 0.44 a$ & $72.3 \pm 0.24$ & $72.8 \pm 0.34$ & $72.5 \pm 0.23$ \\
\hline $11 / 25 / 85$ & $73.0 \pm 0.89$ & $73.3 \pm 0.63$ & $73.3 \pm 0.57$ & $73.9 \pm 0.86$ \\
\hline $11 / 26 / 85$ & $73.0 \pm 0.61$ & $73.4 \pm 0.37$ & $73.3 \pm 0.52$ & $74.0 \pm 0.51$ \\
\hline $11 / 27 / 85$ & $73.1 \pm 0.29$ & $73.4 \perp 0.37$ & $73.5 \pm 0.48$ & $74.2 \pm 0.50$ \\
\hline $11 / 28 / 85$ & $73.2 \pm 0.31$ & $73.9 \pm 0.52$ & $74.2 \pm 0.84$ & $74.2 \pm 0.54$ \\
\hline $11 / 29 / 85$ & $72.5 \pm 0.80$ & $73.5 \pm 0.66$ & $73.9 \pm 0.86$ & $73.9 \pm 0.60$ \\
\hline $11 / 30 / 85$ & $72.6 \pm 0.51$ & $73.0 \pm 0.73$ & $73.5 \pm 0.67$ & $73.9 \pm 0.51$ \\
\hline $12 / 01 / 85$ & $72.6 \pm 0.53$ & $73.0 \pm 0.39$ & $73.4 \pm 0.56$ & $74.0 \pm 0.59$ \\
\hline $12 / 02 / 85$ & $72.8 \pm 0.63$ & $73.2 \pm 0.38$ & $73.3 \pm 0.59$ & $73.5 \pm 0.58$ \\
\hline $12 / 03 / 85$ & $73.4 \pm 0.47$ & $74.0 \pm 0.62$ & $73.4 \pm 0.49$ & $73.5 \pm 0.61$ \\
\hline $12 / 04 / 85$ & $73.2 \pm 0.66$ & $73.8 \pm 0.51$ & $73.4 \pm 0.61$ & $73.6 \pm 0.77$ \\
\hline $12 / 05 / 85$ & $73.6 \pm 0.33$ & $73.6 \pm 0.43$ & $73.4 \pm 0.53$ & $73.5 \pm 0.62$ \\
\hline $12 / 06 / 85$ & $74.7 \pm 0.78$ & $74.2 \pm 0.55$ & $74.1 \pm 0.71$ & $74.0 \pm 0.75$ \\
\hline $12 / 07 / 85$ & $75.5 \pm 0.47$ & $74.7 \pm 0.42$ & $74.4 \pm 0.60$ & $73.7 \pm 0.79$ \\
\hline $12 / 08 / 85$ & $74.8 \pm 0.59$ & $74.6 \pm 0.53$ & $74.2 \pm 0.75$ & $73.3 \pm 0.74$ \\
\hline
\end{tabular}

aDaily mean temperatures were below the minimum specified in the Protocol $\left(72^{\circ} \mathrm{F}\right)$, but remained above the critical minimum temperature $\left(70^{\circ} \mathrm{F}\right)$ 
TABLE B3. Exposure Chamber Relative Humidity $(\mathrm{RH} ; \%$, Daily Mean \pm Standard Deviation) for the Teratology Study of 1,3-Butadiene in Rats

\begin{tabular}{|c|c|c|c|c|}
\hline \multirow{2}{*}{$\begin{array}{c}\text { Exposure } \\
\text { Day }\end{array}$} & \multicolumn{5}{|c|}{ Exposure Chamber (ppm) } \\
\cline { 2 - 5 } & 0 & 40 & 200 & 1000 \\
\hline $11 / 22 / 85$ & $52.2 \pm 6.7$ & $56.0 \pm 5.7$ & $48.8 \pm 8.4$ & $58.2 \pm 4.6$ \\
\hline $11 / 23 / 85$ & $54.2 \pm 4.6$ & $57.5 \pm 5.5$ & $45.3 \pm 3.5$ & $59.9 \pm 5.0$ \\
\hline $11 / 24 / 85$ & $57.4 \pm 5.9$ & $59.0 \pm 3.8$ & $44.9 \pm 2.6$ & $57.4 \pm 5.9$ \\
\hline $11 / 25 / 85$ & $52.1 \pm 6.1$ & $55.4 \pm 2.5$ & $44.0 \pm 2.2$ & $56.1 \pm 2.3$ \\
\hline $11 / 26 / 85$ & $53.9 \pm 4.7$ & $55.2 \pm 2.6$ & $43.4 \pm 2.6$ & $52.2 \pm 6.5$ \\
\hline $11 / 27 / 85$ & $53.6 \pm 3.7$ & $54.0 \pm 5.6$ & $43.0 \pm 2.9$ & $54.7 \pm 3.3$ \\
\hline $11 / 28 / 85$ & $55.7 \pm 1.5$ & $61.8 \pm 12.3$ & $53.5 \pm 12.5$ & $56.1 \pm 10.0$ \\
\hline $11 / 29 / 85$ & $53.7 \pm 4.8$ & $68.7 \pm 6.9$ & $65.7 \pm 6.8$ & $62.3 \pm 4.9$ \\
\hline $11 / 30 / 85$ & $51.6 \pm 11.8$ & $54.9 \pm 15.6$ & $56.0 \pm 14.3$ & $61.4 \pm 6.7$ \\
\hline $12 / 01 / 85$ & $46.1 \pm 2.2$ & $44.0 \pm 2.0$ & $46.1 \pm 1.7$ & $65.0 \pm 2.7$ \\
\hline $12 / 02 / 85$ & $47.4 \pm 2.2$ & $45.3 \pm 2.9$ & $47.7 \pm 3.1$ & $63.0 \pm 3.7$ \\
\hline $12 / 03 / 85$ & $50.7 \pm 2.0$ & $60.4 \pm 13.0$ & $49.4 \pm 3.4$ & $59.7 \pm 6.9$ \\
\hline $12 / 04 / 85$ & $53.7 \pm 2.4$ & $60.3 \pm 5.0$ & $51.4 \pm 2.3$ & $64.6 \pm 3.3$ \\
\hline $12 / 05 / 85$ & $53.4 \pm 4.6$ & $57.2 \pm 4.8$ & $48.8 \pm 3.5$ & $63.0 \pm 5.3$ \\
\hline $12 / 06 / 85$ & $58.4 \pm 3.4$ & $59.3 \pm 3.3$ & $51.6 \pm 3.5$ & $59.1 \pm 5.1$ \\
\hline $12 / 07 / 85$ & $57.7 \pm 4.3$ & $57.0 \pm 5.9$ & $51.9 \pm 4.5$ & $56.6 \pm 8.9$ \\
\hline $12 / 08 / 85$ & $57.7 \pm 5.3$ & $61.7 \pm 5.4$ & $53.4 \pm 3.8$ & $49.4 \pm 2.9$ \\
\hline
\end{tabular}


APPENDIX $C$

CHAMBER UNIFORMITY TESTS FOR 1,3-BUTADIENE CONCENTRATIONS 
TABLE C1. 1,3-Butadiene Gas Concentration Uniformity Testa

\begin{tabular}{|c|c|c|c|}
\hline \multirow{2}{*}{$\begin{array}{c}\text { Sample } \\
\text { Location }\end{array}$} & 40 & 200 & 1000 \\
\cline { 2 - 4 } & 100.3 & 99.6 & 99.8 \\
\hline 1B & 99.5 & 100.0 & 100.2 \\
\hline 1F & 100.3 & 99.6 & 100.1 \\
\hline 2B & 99.2 & 100.1 & 99.7 \\
\hline 2F & 100.5 & 100.0 & 100.0 \\
\hline 3B & 99.7 & 100.0 & 100.1 \\
\hline 3F & 100.8 & 100.2 & 100.3 \\
\hline $4 B$ & 100.0 & 100.3 & 100.3 \\
\hline $4 F$ & 100.5 & 100.3 & 99.6 \\
\hline $5 B$ & 99.0 & 99.7 & 100.1 \\
\hline $5 F$ & 100.5 & 100.5 & 99.5 \\
\hline $6 B$ & 100.5 & 99.8 & 100.4 \\
\hline $6 F$ & $100 \pm 0.6$ & $100 \pm 0.3$ & $100 \pm 0.3$ \\
\hline $\begin{array}{l}\text { Mean } \pm \text { Standard } \\
\text { Deviation }\end{array}$ & & & \\
\hline
\end{tabular}

aResults expressed as percent normalized average concentration at 12 sample locations in each chamber. 
TPY MIEASUREMENTS

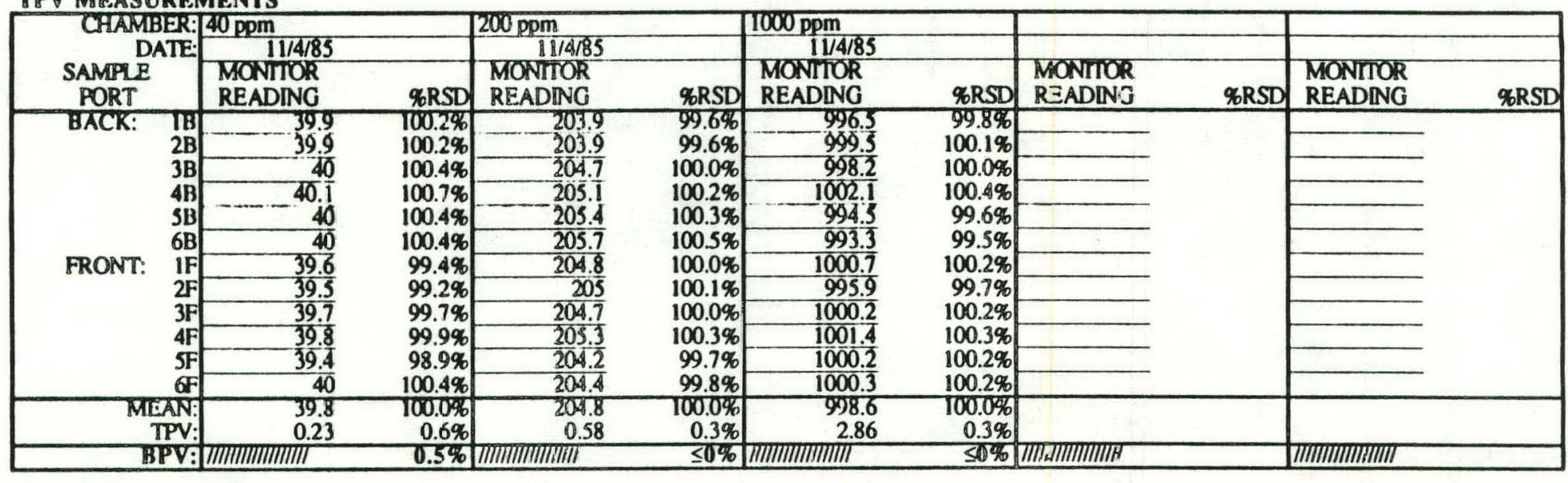

WPV MEASUREMENTS

\begin{tabular}{|c|c|c|c|c|c|c|c|c|}
\hline $\begin{array}{l}\text { IN-LINE IsI } \\
\text { 2nd } \\
\text { 3rd }\end{array}$ & $\begin{array}{r}40 \\
-40 \\
40 \\
\end{array}$ & $\begin{array}{l}100.3 \% \\
100.0 \% \\
99.7 \%\end{array}$ & $\begin{array}{r}206 \\
204 \\
205 \\
\end{array}$ & $\begin{array}{r}100.5 \% \\
99.5 \% \\
100.0 \% \\
\end{array}$ & $\begin{array}{r}985 \\
-997 \\
996\end{array}$ & $\begin{array}{r}99.2 \% \\
100.4 \% \\
100.4 \%\end{array}$ & - & \\
\hline $\begin{array}{l}\text { TMEAN: } \\
\text { WPV: }\end{array}$ & $\begin{array}{l}39.9 \\
0.10\end{array}$ & $\begin{array}{r}100.0 \% \\
0.3 \%\end{array}$ & $\begin{array}{r}204.9 \\
1.00\end{array}$ & $\begin{array}{r}100.0 \% \\
0.5 \%\end{array}$ & $\begin{array}{r}992.3 \\
6.70\end{array}$ & $\begin{array}{r}100.0 \% \\
0.7 \%\end{array}$ & & \\
\hline
\end{tabular}

MONITOR TYPE: GC 809569

SERIAL \# :

MONITOR DATA

COMMENTS:

GC monitor port 2B 6 Tong $1 / 4^{\pi}$ OD Tellon line added to the regular GC sampling line without anirrals

ENTERED BY: MLClark DATE 1231/85 REVIEWEDBY: $1 / 2 \mathrm{fChL}$ DATE: $/ 3 / 36$

FIGURE C1. Chamber Uniformity Data Sheet--Gas Chromatography Monitoring 
CHAMBER UNIFORMITY DATA SHEET

COMPOUND: IRT 1,3 BUTADIENE

\section{TPV MEASUREMENTS}

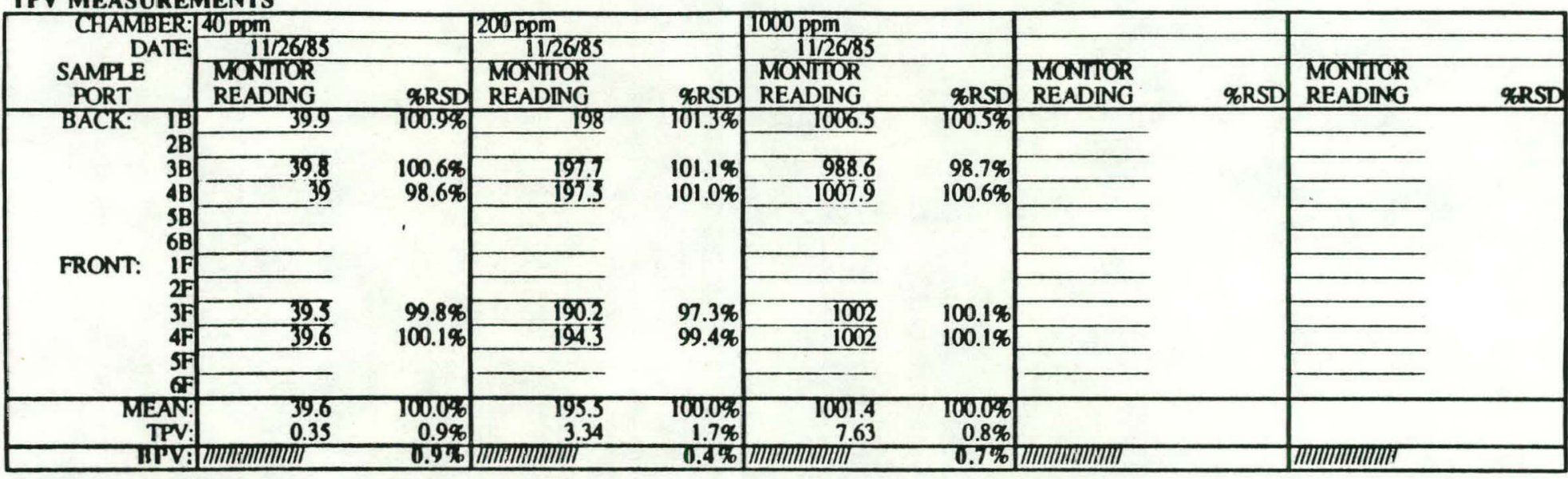

ڤ

EXPOSURE ROOM NUMBER:

436
$100.1 \%$

$99.8 \%$

$100.1 \%$

$100.0 \%$

\begin{tabular}{r|rr}
$98.2 \%$ & 1004 & $99.8 \%$ \\
$101.4 \%$ & 1007 & $100.1 \%$ \\
\hline $100.0 \%$ & 1005.7 & $100.0 \%$ \\
\hline $1.7 \%$ & 1.84 & $0.2 \%$
\end{tabular}

$1.7 \%$

MONITOR TYPE: GC.N809569

MONTTOR DATA LOCATION: BNWLab notebook " S5IIT2 pape 7

COMMENTS: Chamber balance performed with chambers containing animals

FNTERED BY: MLClark

DATE:

12/31/85

REVIEWED BY: MPClac

DATE: $1 / 3 / 86$

FIGURE C2. Chamber Uniformity Data Sheet--Chamber Balance 


\section{APPENDIX D}

\section{HEALTH EVALUATIONS OF EXPERIMENTAL ANIMALS}




\begin{abstract}
Date November 22, 1985
To P. L. Hackett

From

S. E. Rowe<smiles>CCCCCCCC</smiles>

Subject Pre-Exposure Health Evaluation, Butadiene Teratology Rats
\end{abstract}

Ten $C D(S D)$ rats $(5 \mathrm{M}, 5 \mathrm{~F}$ ) randomly selected from the group received for the study were submitted on 11-13-85 for health evaluation. The rats were received on 10-30-85 from Charles River, Portage Area 6. Two shipment numbers were assigned ( 860009 for the males, 860010 for the females) although both sexes were shipped together and received at the same time. Health evaluation findings are recorded on the attached lab report $(\mathrm{N}-114)$.

There was some evidence of very slight irritation to the eyes and respiratory tract based on clinical signs and pathologic findings. No significant pathogens were found in aerobic cultures of nasopharyngeal washes and serologic tests for antibodies to viral pathogens were negative. I observed the remaining rats in the quarantine room on $11 / 15$ and found them clinically normal. I could not find any evidence of a possible cause for eye and respiratory irritation. Perhaps this was a residual effect from something which happened in transit.

On 11-18-85, a dead rat from the group. was submitted for examination. He had been killed when found to have a nasal and ocular discharge. No significant bacterial pathogens were found from nasopharyngeal cultures. No serologic testing was possible since the rat was submitted dead. The method of euthanasia resulted in hemorrhage in the nasopharyngeal area as well as in the CNS area and this interfered with the pathologic evaluation. There was some pathologic evidence of mild upper respiratory tract inflammation.

The investigation of the mild upper respiratory signs and lesions seen in some rats could have been continued with microscopic examination of nasal turbinates but this could not have been completed until the study was well underway. I don't believe these effects were caused by infection and feel reasonably confident that whatever the cause, it will not influence the results of this study. The remaining population is not noticeably affected at this point.

This group was verbally released from quarantine on 11-21-85. 
APPENDIXE

INDIVIDUAL VALUES FOR FETAL STATUS, SEX AND

BODY WEIGHT, AND PLACENTAL WEIGHT

TJM-482A 
BUTADIENE RAT FETAL DATA

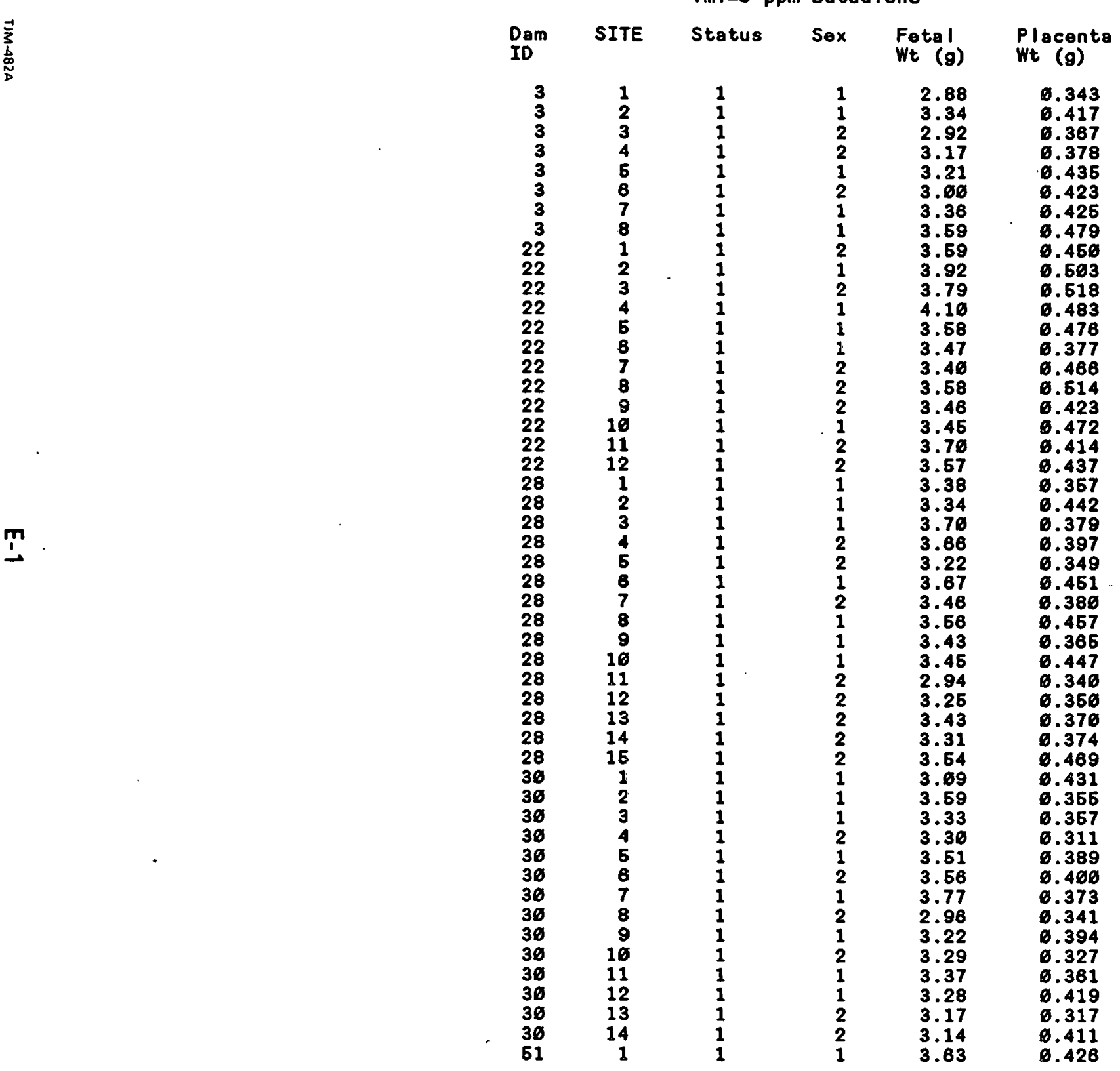

Status: 1 = Live; 2 = Early Resorption; 4 = Late Resorption; $5=$ Live 
BUTADIENE RAT FETAL DATA

TMT=E ppm Butadiene

\begin{tabular}{|c|c|c|c|c|c|}
\hline $\begin{array}{l}\text { Dam } \\
\text { ID }\end{array}$ & SITE & Status & Sex & $\begin{array}{l}\text { Fotal } \\
\text { Wt (g) }\end{array}$ & $\begin{array}{l}P \text { I scenta } \\
W t \text { (g) }\end{array}$ \\
\hline $\begin{array}{l}51 \\
51 \\
51 \\
51 \\
51 \\
51 \\
51 \\
51 \\
51 \\
51 \\
51 \\
61 \\
51 \\
51 \\
61 \\
61 \\
61 \\
61 \\
61 \\
61 \\
61 \\
61 \\
61 \\
61 \\
61 \\
61 \\
61 \\
61 \\
66 \\
66 \\
66 \\
66 \\
66 \\
66 \\
66 \\
66 \\
66 \\
66 \\
66 \\
66 \\
68 \\
68 \\
68 \\
68 \\
68 \\
68 \\
68 \\
68 \\
68 \\
68\end{array}$ & $\begin{array}{r}2 \\
3 \\
4 \\
5 \\
6 \\
7 \\
8 \\
9 \\
16 \\
11 \\
12 \\
13 \\
14 \\
15 \\
1 \\
2 \\
3 \\
4 \\
5 \\
6 \\
7 \\
8 \\
9 \\
18 \\
11 \\
12 \\
13 \\
14 \\
1 \\
2 \\
3 \\
4 \\
5 \\
6 \\
7 \\
8 \\
9 \\
18 \\
11 \\
12 \\
1 \\
2 \\
3 \\
4 \\
6 \\
8 \\
7 \\
8 \\
8 \\
18\end{array}$ & $\begin{array}{l}2 \\
1 \\
1 \\
1 \\
1 \\
1 \\
1 \\
1 \\
1 \\
1 \\
1 \\
1 \\
1 \\
1 \\
1 \\
1 \\
1 \\
1 \\
1 \\
1 \\
1 \\
1 \\
1 \\
1 \\
1 \\
1 \\
1 \\
1 \\
2 \\
1 \\
1 \\
1 \\
1 \\
1 \\
1 \\
2 \\
1 \\
1 \\
2 \\
1 \\
1 \\
1 \\
1 \\
1 \\
1 \\
1 \\
1 \\
1 \\
1 \\
1\end{array}$ & $\begin{array}{r}-1 \\
2 \\
2 \\
2 \\
1 \\
1 \\
1 \\
2 \\
1 \\
1 \\
1 \\
1 \\
2 \\
2 \\
1 \\
1 \\
1 \\
2 \\
2 \\
2 \\
1 \\
2 \\
1 \\
1 \\
1 \\
2 \\
1 \\
1 \\
1 \\
1 \\
-1 \\
2 \\
1 \\
2 \\
2 \\
1 \\
1 \\
-1 \\
2 \\
1 \\
-1 \\
2 \\
2 \\
2 \\
1 \\
1 \\
2 \\
1 \\
2 \\
1 \\
1 \\
1 \\
1\end{array}$ & $\begin{array}{r}-1.60 \\
3.39 \\
3.58 \\
3.53 \\
3.84 \\
3.33 \\
3.85 \\
3.39 \\
3.89 \\
3.71 \\
3.83 \\
3.78 \\
3.31 \\
2.99 \\
3.97 \\
4.63 \\
3.72 \\
3.65 \\
3.58 \\
4.62 \\
3.42 \\
3.41 \\
3.53 \\
3.44 \\
3.79 \\
3.76 \\
4.18 \\
3.76 \\
-1.66 \\
3.61 \\
3.81 \\
3.40 \\
3.38 \\
3.49 \\
3.61 \\
-1.06 \\
2.91 \\
3.37 \\
-1.010 \\
3.44 \\
2.76 \\
2.91 \\
3.16 \\
3.39 \\
2.97 \\
3.18 \\
3.12 \\
3.84 \\
3.27 \\
2.71\end{array}$ & 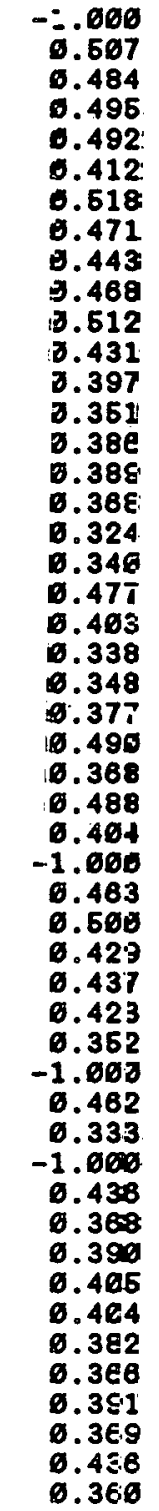 \\
\hline
\end{tabular}

Status: 1 = Live; 2 = Early Resorption; 4 = Late Resorption; 6 = Live 


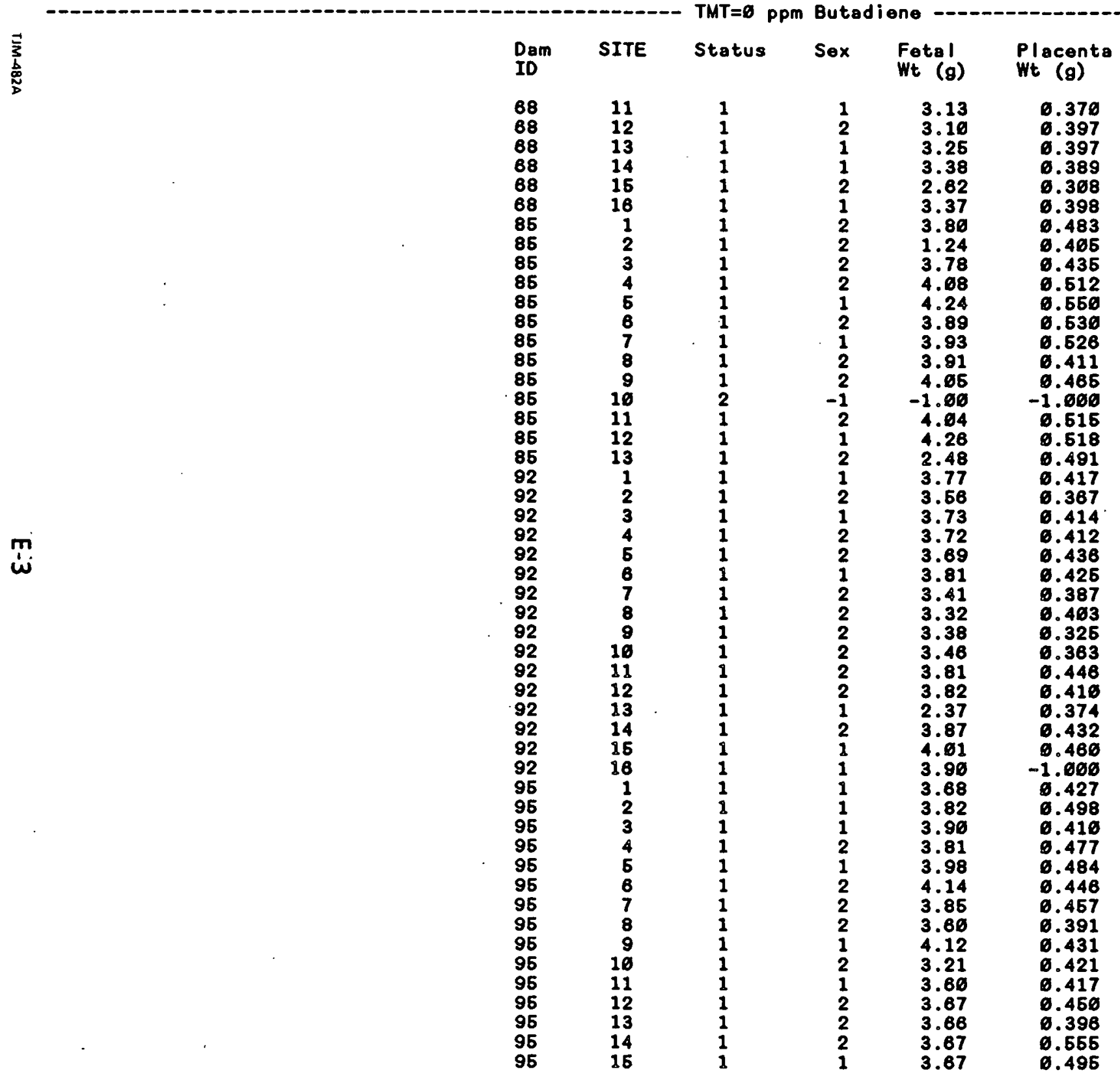

Status: 1 = Live; 2 = Early Resorption; $4=$ Late Resorption; 5 = Live Sex: Male $=1$; Female $=2$ 
BUTADIENE RAT FETAL DATA

TMT=ø ppm Butadiene

壳

\begin{tabular}{|c|c|c|c|c|c|}
\hline $\begin{array}{l}\text { Dam } \\
\text { ID }\end{array}$ & SITE & Status & Sex & $\begin{array}{l}\text { Fotal } \\
\text { Wt (g) }\end{array}$ & $\begin{array}{l}\text { Placenta } \\
\text { Wt (g) }\end{array}$ \\
\hline $\begin{array}{l}95 \\
95 \\
98 \\
98 \\
98 \\
98 \\
98 \\
98 \\
98 \\
98 \\
98 \\
98 \\
98 \\
98 \\
98 \\
98 \\
98 \\
164 \\
164 \\
164 \\
164 \\
164 \\
164 \\
164 \\
164 \\
164 \\
164 \\
164 \\
164 \\
164 \\
116 \\
116 \\
116 \\
115 \\
116 \\
116 \\
116 \\
115 \\
116 \\
116 \\
116 \\
115 \\
115 \\
116 \\
116 \\
115 \\
116 \\
121 \\
121 \\
121\end{array}$ & $\begin{array}{r}16 \\
17 \\
1 \\
2 \\
3 \\
4 \\
5 \\
6 \\
7 \\
8 \\
9 \\
10 \\
11 \\
12 \\
13 \\
14 \\
15 \\
1 \\
2 \\
3 \\
4 \\
5 \\
8 \\
7 \\
8 \\
9 \\
16 \\
11 \\
12 \\
13 \\
1 \\
2 \\
3 \\
4 \\
5 \\
6 \\
7 \\
8 \\
9 \\
16 \\
11 \\
12 \\
13 \\
14 \\
15 \\
16 \\
17 \\
1 \\
2 \\
3\end{array}$ & $\begin{array}{l}1 \\
1 \\
1 \\
1 \\
1 \\
1 \\
1 \\
1 \\
1 \\
4 \\
1 \\
1 \\
1 \\
1 \\
1 \\
1 \\
1 \\
1 \\
1 \\
1 \\
1 \\
1 \\
1 \\
1 \\
1 \\
1 \\
1 \\
1 \\
1 \\
1 \\
4 \\
1 \\
1 \\
1 \\
1 \\
2 \\
1 \\
2 \\
1 \\
1 \\
1 \\
1 \\
1 \\
1 \\
1 \\
1 \\
1 \\
1\end{array}$ & $\begin{array}{r}1 \\
2 \\
1 \\
2 \\
2 \\
1 \\
2 \\
2 \\
1 \\
-1 \\
1 \\
1 \\
2 \\
2 \\
2 \\
2 \\
2 \\
2 \\
1 \\
1 \\
1 \\
2 \\
2 \\
2 \\
2 \\
1 \\
2 \\
1 \\
2 \\
1 \\
1 \\
-1 \\
2 \\
2 \\
2 \\
1 \\
2 \\
-1 \\
1 \\
-1 \\
2 \\
1 \\
2 \\
1 \\
2 \\
2 \\
2 \\
2 \\
1 \\
1 \\
1 \\
\end{array}$ & $\begin{array}{r}3.93 \\
3.56 \\
3.63 \\
3.62 \\
3.66 \\
3.88 \\
3.84 \\
3.91 \\
2.83 \\
-1.60 \\
3.31 \\
3.61 \\
3.76 \\
3.78 \\
3.67 \\
3.76 \\
3.13 \\
3.82 \\
3.94 \\
3.77 \\
3.37 \\
3.49 \\
3.11 \\
3.48 \\
3.46 \\
3.39 \\
3.76 \\
3.43 \\
3.83 \\
3.65 \\
-1.86 \\
3.24 \\
3.34 \\
3.33 \\
3.79 \\
3.35 \\
-1.68 \\
3.42 \\
-1.06 \\
3.49 \\
3.74 \\
3.23 \\
3.34 \\
3.21 \\
3.31 \\
3.36 \\
3.58 \\
3.56 \\
3.78 \\
3.84\end{array}$ & 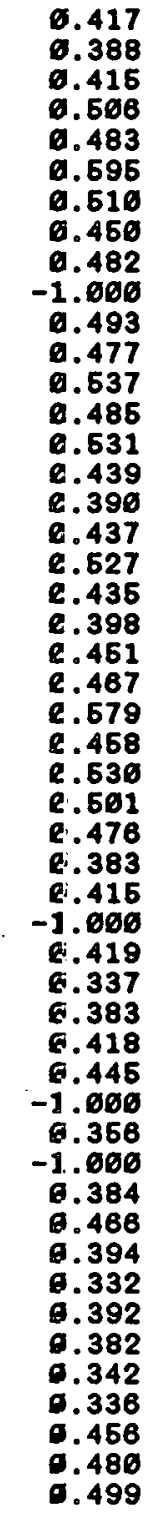 \\
\hline
\end{tabular}

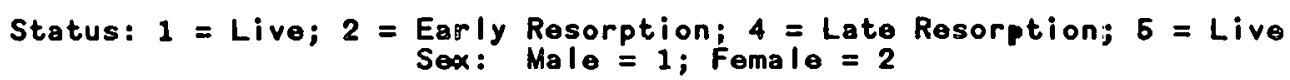


BUTADIENE RAT FETAL DATA

TMT=ø ppm Butadiene

\begin{tabular}{|c|c|c|c|c|c|}
\hline $\begin{array}{l}\text { Dam } \\
\text { Io }\end{array}$ & SITE & Status & Sex & $\begin{array}{l}\text { Fetal } \\
W t \text { (g) }\end{array}$ & $\begin{array}{l}\text { P lacenta } \\
\text { Wt (g) }\end{array}$ \\
\hline $\begin{array}{l}121 \\
121 \\
121 \\
121 \\
121 \\
121 \\
121 \\
121 \\
121 \\
121 \\
121 \\
121 \\
121 \\
121 \\
122 \\
122 \\
122 \\
122 \\
122 \\
122 \\
122 \\
122 \\
122 \\
122 \\
122 \\
122 \\
122 \\
122 \\
122 \\
122 \\
123 \\
123 \\
123 \\
123 \\
123 \\
123 \\
123 \\
123 \\
123 \\
124 \\
124 \\
124 \\
124 \\
124 \\
124 \\
124 \\
124 \\
124 \\
124 \\
124\end{array}$ & $\begin{array}{r}4 \\
5 \\
6 \\
7 \\
8 \\
9 \\
16 \\
11 \\
12 \\
13 \\
14 \\
15 \\
16 \\
17 \\
1 \\
2 \\
3 \\
4 \\
6 \\
6 \\
7 \\
8 \\
9 \\
16 \\
11 \\
12 \\
13 \\
14 \\
16 \\
16 \\
1 \\
2 \\
3 \\
4 \\
5 \\
6 \\
7 \\
8 \\
9 \\
1 \\
2 \\
3 \\
4 \\
5 \\
6 \\
7 \\
8 \\
9 \\
16 \\
11\end{array}$ & $\begin{array}{l}1 \\
1 \\
1 \\
1 \\
1 \\
1 \\
1 \\
1 \\
1 \\
1 \\
1 \\
1 \\
1 \\
1 \\
1 \\
1 \\
1 \\
1 \\
1 \\
1 \\
1 \\
1 \\
1 \\
1 \\
1 \\
1 \\
1 \\
1 \\
1 \\
1 \\
1 \\
1 \\
1 \\
1 \\
1 \\
1 \\
1 \\
1 \\
1 \\
1 \\
1 \\
1 \\
1 \\
1 \\
1 \\
1 \\
1 \\
1 \\
1 \\
1\end{array}$ & $\begin{array}{l}2 \\
2 \\
2 \\
1 \\
1 \\
1 \\
2 \\
1 \\
2 \\
1 \\
1 \\
1 \\
2 \\
1 \\
2 \\
2 \\
2 \\
1 \\
1 \\
1 \\
2 \\
2 \\
2 \\
1 \\
1 \\
1 \\
1 \\
1 \\
1 \\
1 \\
1 \\
2 \\
1 \\
2 \\
2 \\
2 \\
1 \\
2 \\
1 \\
2 \\
1 \\
2 \\
2 \\
1 \\
1 \\
1 \\
1 \\
2 \\
1 \\
2\end{array}$ & $\begin{array}{l}3.46 \\
3.16 \\
3.81 \\
3.69 \\
3.74 \\
3.78 \\
3.46 \\
3.58 \\
3.62 \\
3.83 \\
3.92 \\
3.88 \\
3.61 \\
3.67 \\
3.26 \\
3.67 \\
3.53 \\
3.61 \\
3.62 \\
3.69 \\
3.61 \\
3.68 \\
3.84 \\
3.69 \\
3.87 \\
3.68 \\
3.64 \\
3.72 \\
3.63 \\
3.65 \\
3.67 \\
3.76 \\
3.63 \\
3.67 \\
3.77 \\
3.82 \\
3.98 \\
3.79 \\
4.11 \\
3.14 \\
3.27 \\
2.94 \\
3.28 \\
3.60 \\
3.66 \\
3.67 \\
3.67 \\
2.78 \\
3.16 \\
3.16\end{array}$ & 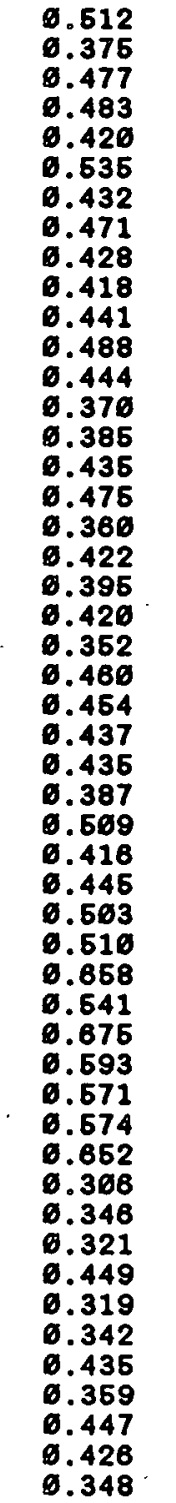 \\
\hline
\end{tabular}

in 


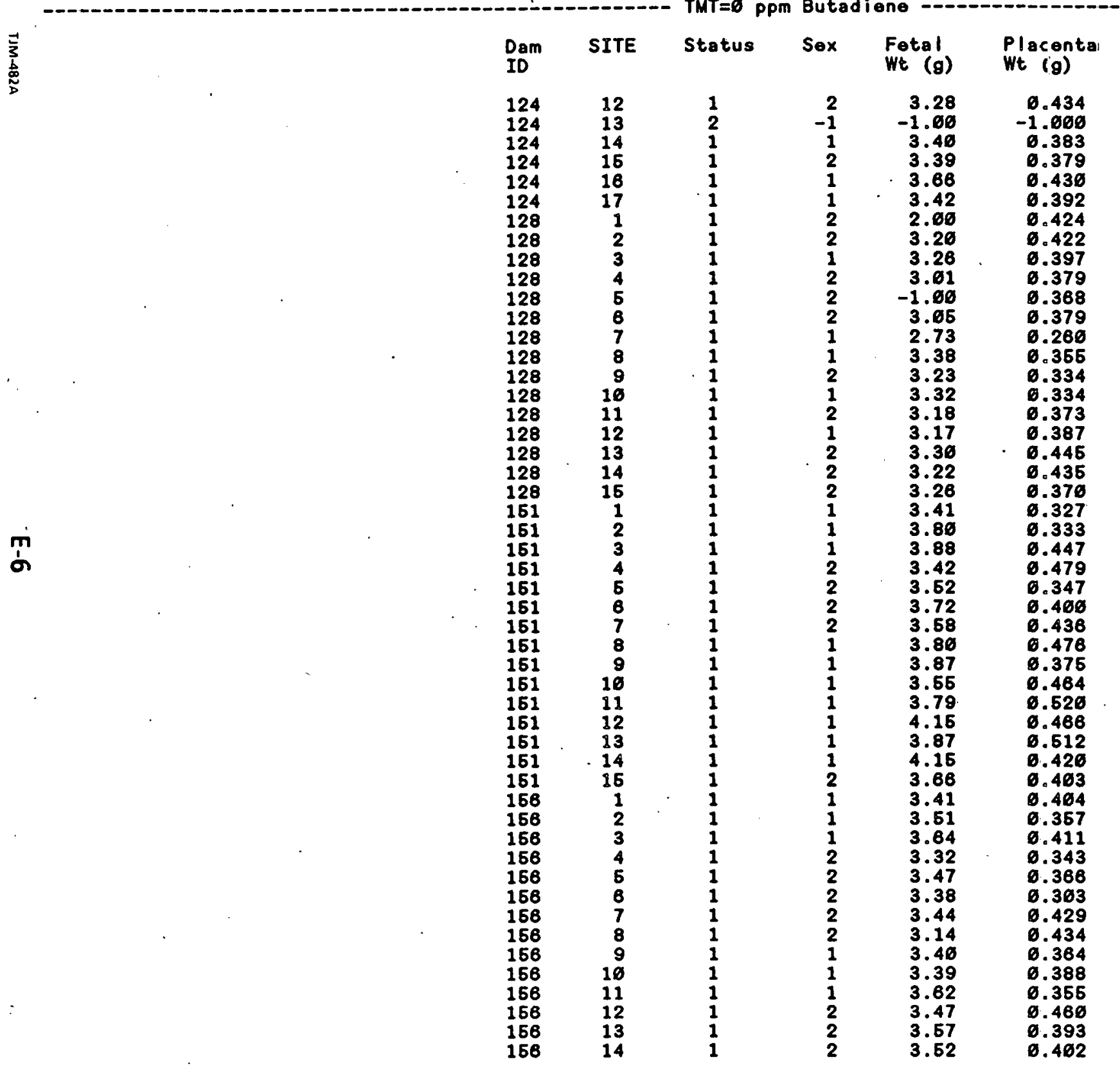

Status: 1 = Live; 2 = Early Resorption; 4 = Late Resorption; 6 = Live 
BUTADIENE RAT FETAL DATA

TMT=8 ppm Butadiene

$\stackrel{m}{\stackrel{m}{2}}$

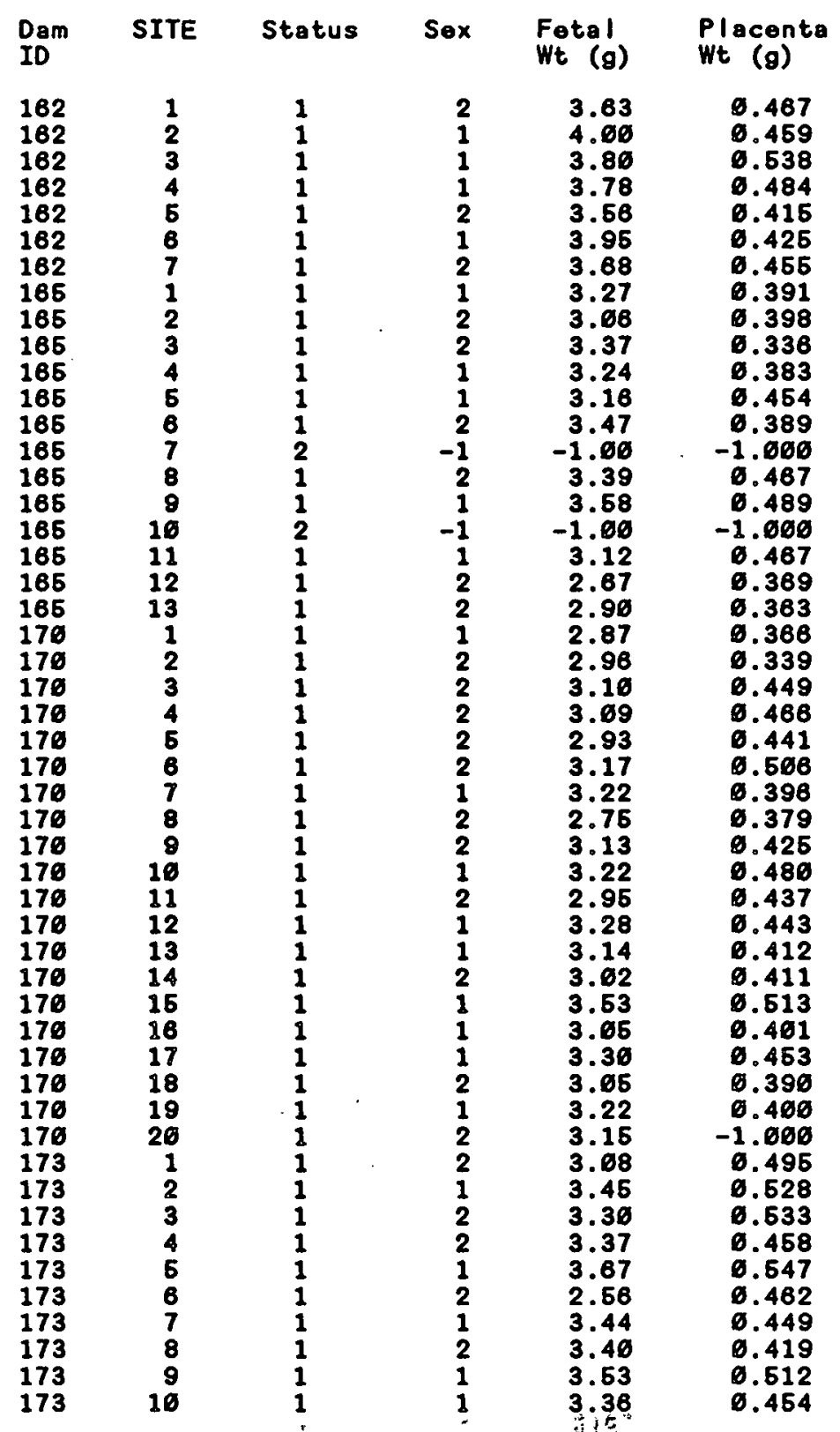

Status: 1 = Live; 2 = Early Resorption; 4 = Late Resorption; 6 = Live 
BUTADIENE RAT FETAL DATA

TMT=ø ppm. Butadiene

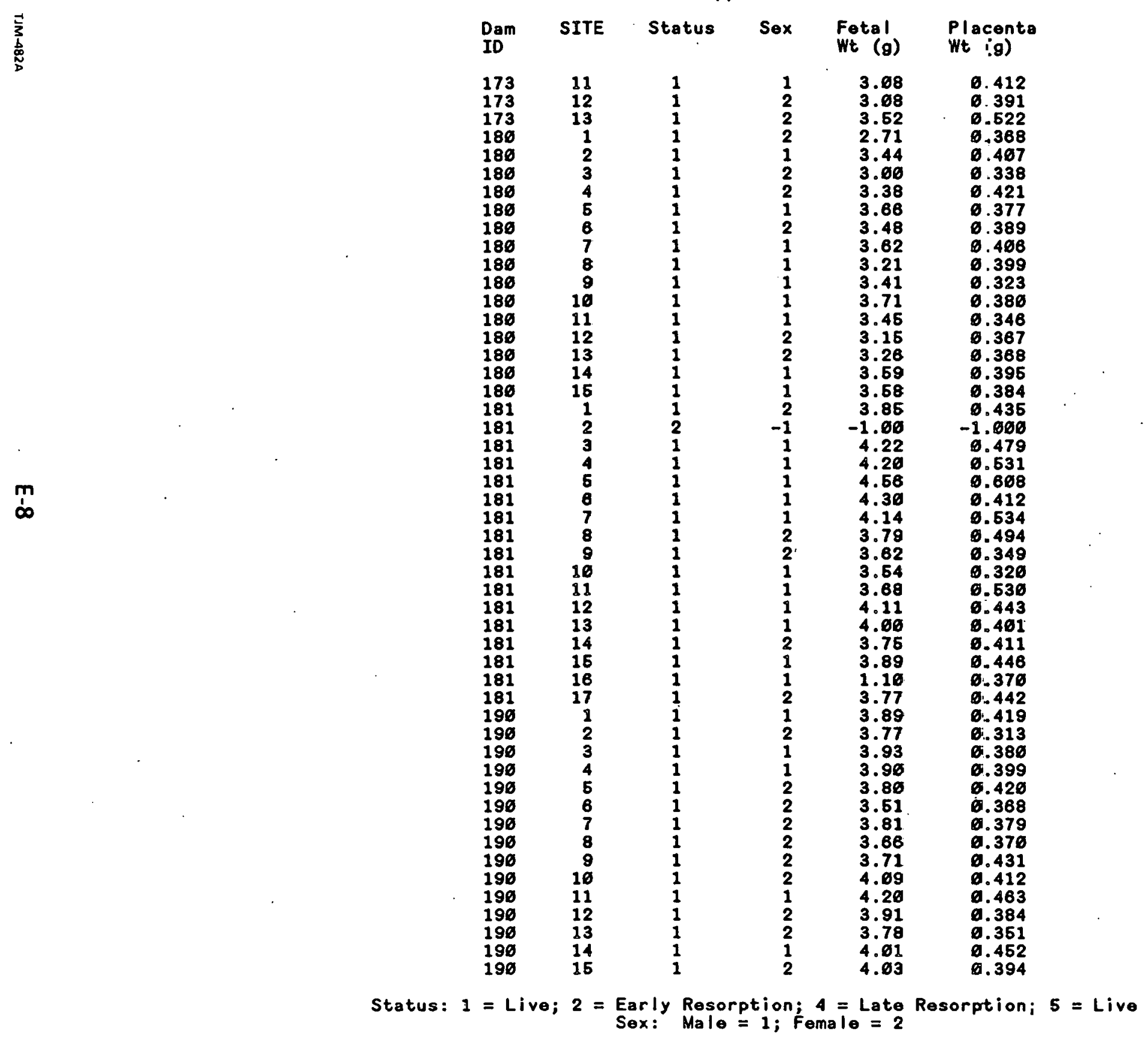


BUTADIENE RAT FETAL DATA

TMT=0 ppm Butadiene

$\begin{array}{lccccc}\text { Dam } & \text { SITE } & \text { Status } & \text { Sex } & \begin{array}{l}\text { Fetal } \\ \text { It (g) }\end{array} & \begin{array}{c}\text { Placenta } \\ W t(g)\end{array} \\ 190 & 16 & 1 & 1 & 3.61 & 0.431 \\ 190 & 17 & 1 & 1 & 3.64 & 0.392\end{array}$

$\prod_{i}^{m}$ $\begin{aligned} \text { Status: } 1=\text { Live; } 2 \text { = Early Resorption; } 4=\text { Late Resorption; } 5=\text { Live } & \text { Sex: Male }=1 ; \text { Female }=2\end{aligned}$ 
BUTAOIENE RAT FETAL DATA

TMT $=40$ ppm Butadiene

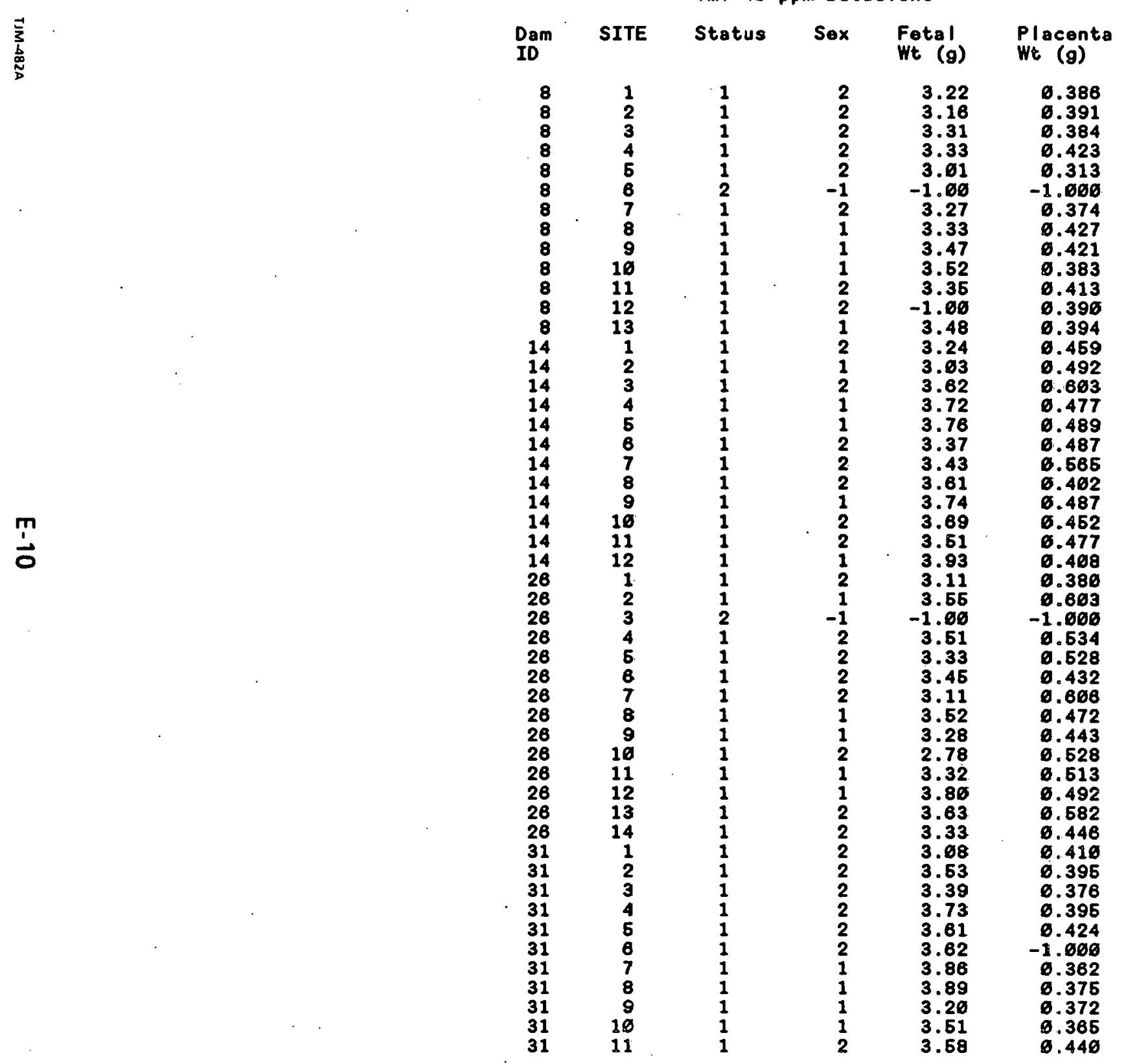

Status: 1 = Live; 2 = Early Resorption; $4=$ Late Resorption; 6 = Live Sex: Male $=1$; Female $=2$ 
BUTADIENE RAT FETAL DATA

TMT $=40$ Ppm Butadiene

\begin{tabular}{|c|c|c|c|c|c|}
\hline $\begin{array}{l}\text { Darm } \\
\text { ID }\end{array}$ & SITE & Status & Sex & $\begin{array}{l}\text { Fetal } \\
W_{t}(g)\end{array}$ & $\begin{array}{l}\text { Placenta } \\
\text { Wt (g) }\end{array}$ \\
\hline 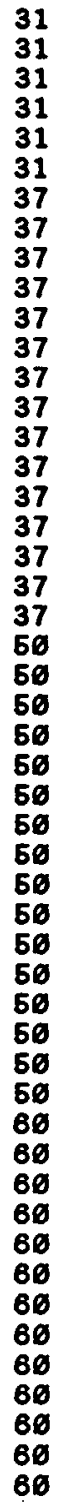 & $\begin{array}{r}12 \\
13 \\
14 \\
16 \\
16 \\
17 \\
1 \\
2 \\
3 \\
4 \\
5 \\
6 \\
7 \\
8 \\
9 \\
16 \\
11 \\
12 \\
13 \\
14 \\
15 \\
1 \\
2 \\
3 \\
4 \\
5 \\
6 \\
7 \\
8 \\
8 \\
16 \\
11 \\
12 \\
13 \\
14 \\
15 \\
16 \\
1 \\
2 \\
3 \\
4 \\
5 \\
6 \\
7 \\
8 \\
9 \\
16 \\
11 \\
12 \\
13\end{array}$ & $\begin{array}{l}1 \\
1 \\
1 \\
1 \\
1 \\
1 \\
1 \\
1 \\
1 \\
1 \\
1 \\
1 \\
1 \\
1 \\
1 \\
1 \\
1 \\
1 \\
1 \\
1 \\
1 \\
1 \\
1 \\
1 \\
1 \\
1 \\
1 \\
1 \\
1 \\
1 \\
1 \\
1 \\
1 \\
1 \\
1 \\
1 \\
1 \\
1 \\
1 \\
1 \\
1 \\
1 \\
1 \\
1 \\
1 \\
1 \\
1 \\
1 \\
1 \\
1\end{array}$ & $\begin{array}{l}1 \\
1 \\
1 \\
2 \\
1 \\
2 \\
2 \\
1 \\
2 \\
2 \\
2 \\
1 \\
1 \\
2 \\
1 \\
2 \\
2 \\
2 \\
1 \\
1 \\
1 \\
1 \\
2 \\
2 \\
1 \\
2 \\
2 \\
1 \\
2 \\
2 \\
2 \\
1 \\
1 \\
1 \\
1 \\
2 \\
1 \\
2 \\
1 \\
1 \\
1 \\
1 \\
2 \\
1 \\
1 \\
2 \\
1 \\
1 \\
1 \\
1 \\
1 \\
2 \\
2 \\
2\end{array}$ & $\begin{array}{l}3.19 \\
3.66 \\
3.87 \\
3.46 \\
3.58 \\
3.42 \\
3.18 \\
3.28 \\
3.42 \\
3.36 \\
2.92 \\
3.38 \\
3.23 \\
3.68 \\
3.60 \\
3.25 \\
3.67 \\
3.26 \\
3.25 \\
3.37 \\
3.51 \\
3.86 \\
3.55 \\
3.45 \\
3.87 \\
3.55 \\
3.51 \\
3.66 \\
3.11 \\
3.31 \\
3.72 \\
3.66 \\
3.76 \\
3.66 \\
3.51 \\
3.66 \\
3.94 \\
3.19 \\
3.36 \\
3.66 \\
3.70 \\
3.76 \\
3.47 \\
3.60 \\
3.47 \\
2.63 \\
3.28 \\
3.46 \\
3.33 \\
3.63\end{array}$ & 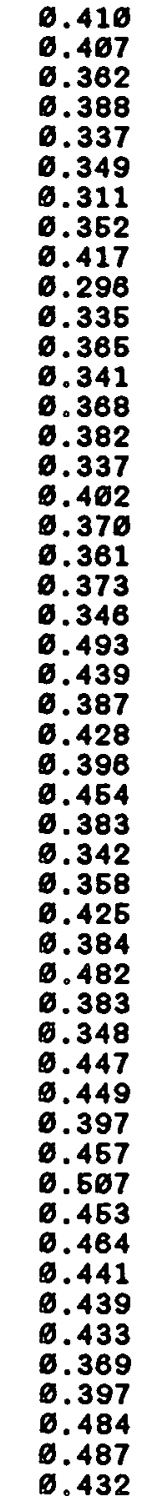 \\
\hline
\end{tabular}

Status: 1 = Live; 2 = Early Resorption; 4 = Late Resorption; $5=$ Live 
TMT=46 ppm Butadiene

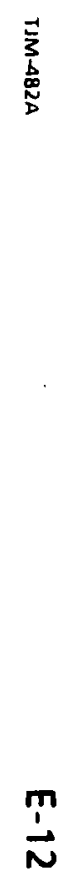

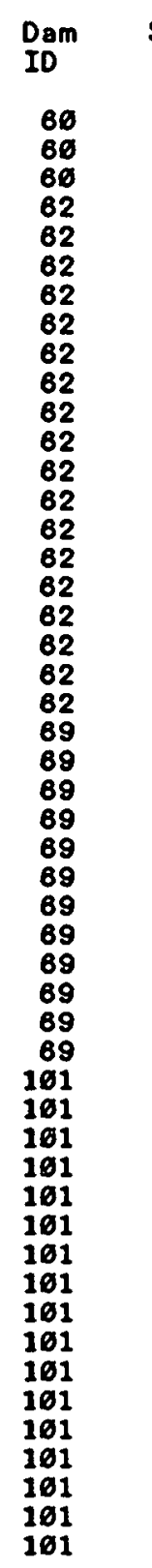

SITE Status

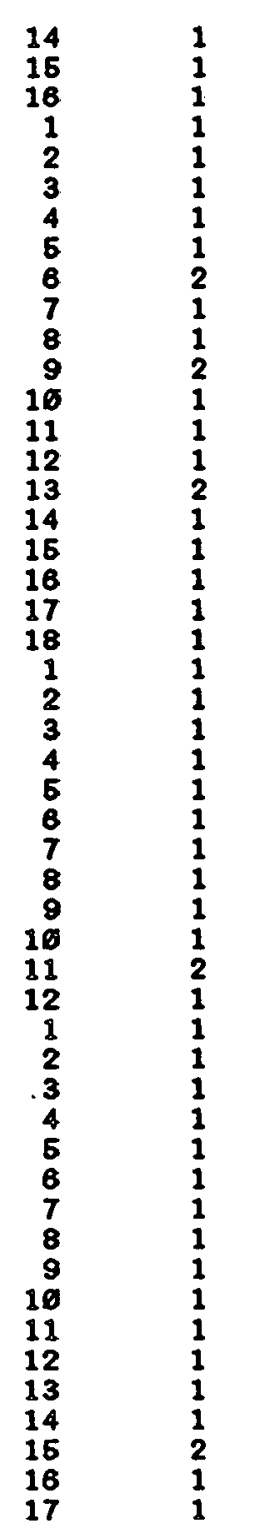

Sex

1
2
2
2
1
1

otol

Plocenta

Wt (g) Wt (g)

$\stackrel{m}{N}$

Status: 1 = Live; 2 = Early Resorption: 4 = Late Resorption; 5 = Live Sox: Male = 1; Fomale $=2$ 


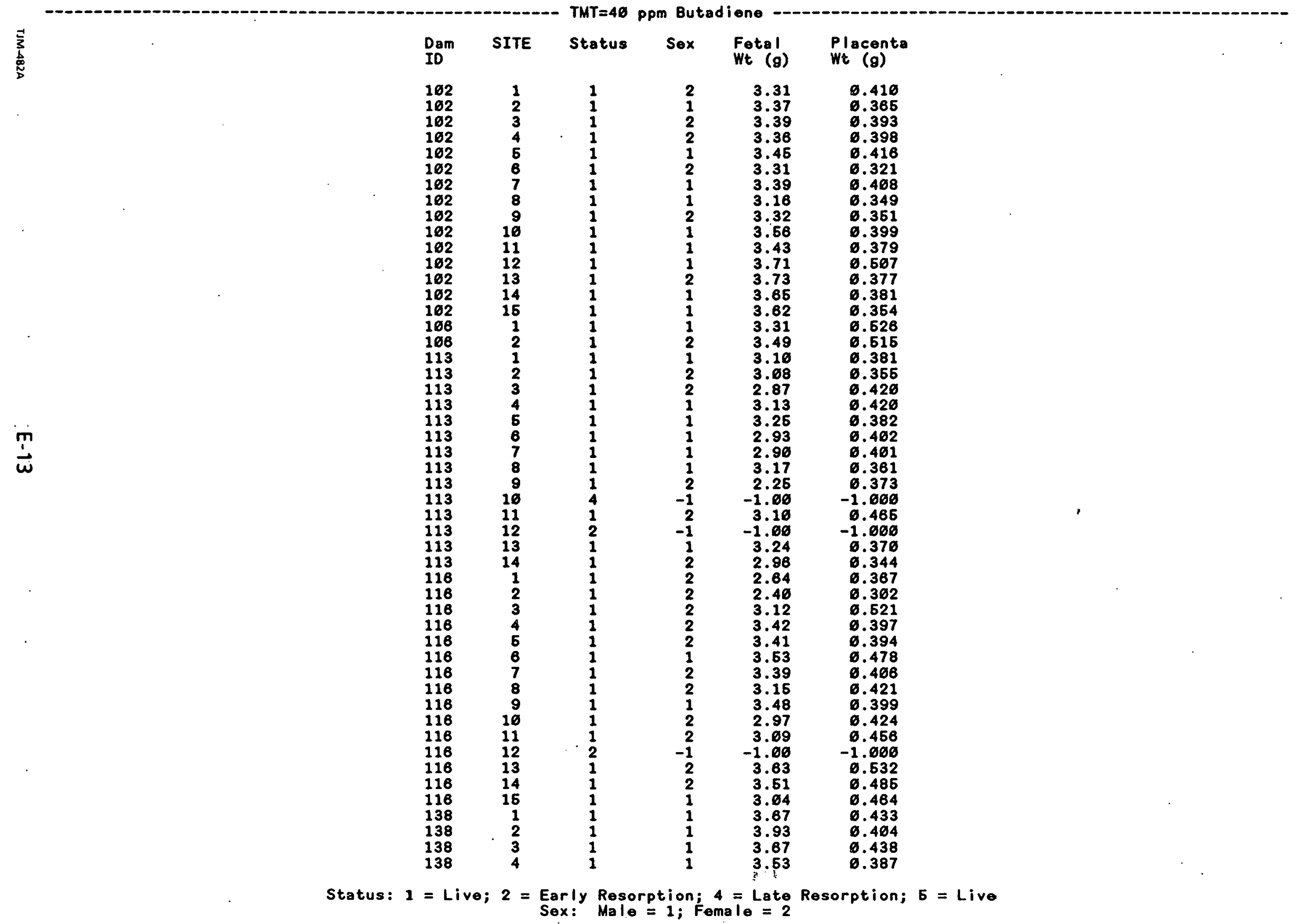


BUTADIENE RAT FETAL DATA

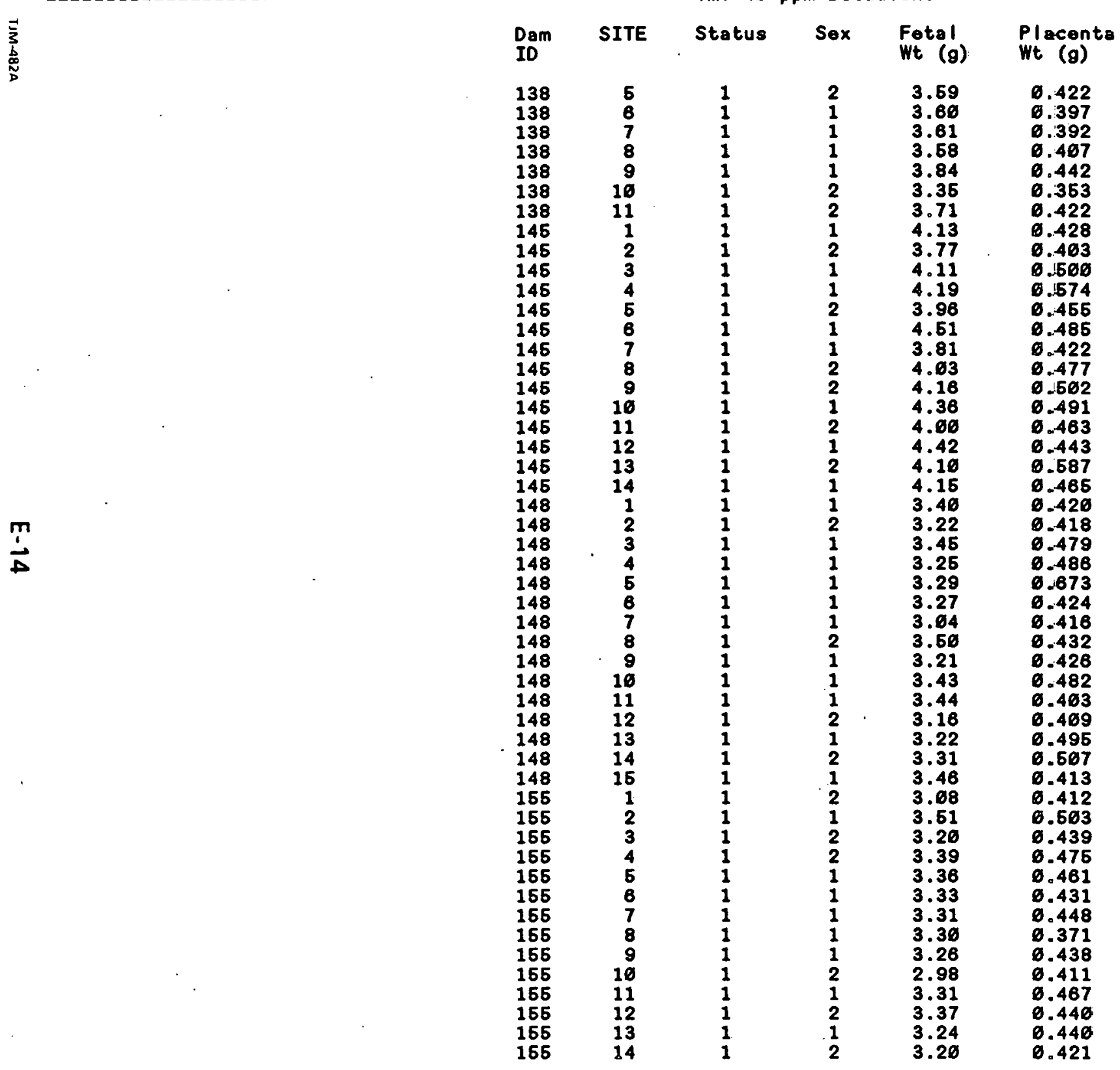

Status: 1 = Live; 2 = Early Resorption; 4 = Late Resorftion: 6 = Live 
$$
T M T=40 \text { ppm Butadiene }
$$

\begin{tabular}{|c|c|c|c|c|c|}
\hline $\begin{array}{l}\text { Dam } \\
\text { ID }\end{array}$ & SITE & Status & Sex & $\begin{array}{l}\text { Fetol } \\
\text { Wt (g) }\end{array}$ & $\begin{array}{l}\text { Placenta } \\
\text { Wt (g) }\end{array}$ \\
\hline $\begin{array}{l}165 \\
165 \\
166 \\
168 \\
166 \\
166 \\
166 \\
166 \\
166 \\
166 \\
166 \\
168 \\
166 \\
166 \\
166 \\
166 \\
166 \\
171 \\
171 \\
171 \\
171 \\
171 \\
171 \\
171 \\
171 \\
171 \\
171 \\
171 \\
171 \\
171 \\
171 \\
171 \\
186 \\
186 \\
186 \\
186 \\
186 \\
186 \\
186 \\
186 \\
186 \\
194 \\
194 \\
194 \\
194 \\
194 \\
194 \\
194 \\
194 \\
194\end{array}$ & $\begin{array}{r}15 \\
16 \\
1 \\
2 \\
3 \\
4 \\
5 \\
6 \\
7 \\
8 \\
9 \\
16 \\
11 \\
12 \\
13 \\
14 \\
15 \\
1 \\
2 \\
3 \\
4 \\
5 \\
6 \\
7 \\
8 \\
9 \\
16 \\
11 \\
12 \\
13 \\
14 \\
16 \\
1 \\
2 \\
3 \\
4 \\
5 \\
6 \\
7 \\
8 \\
9 \\
1 \\
2 \\
3 \\
4 \\
5 \\
6 \\
7 \\
8 \\
9\end{array}$ & $\begin{array}{l}1 \\
1 \\
1 \\
1 \\
2 \\
1 \\
1 \\
1 \\
1 \\
1 \\
1 \\
1 \\
1 \\
1 \\
1 \\
1 \\
1 \\
1 \\
1 \\
1 \\
1 \\
1 \\
1 \\
1 \\
1 \\
2 \\
1 \\
1 \\
1 \\
1 \\
1 \\
1 \\
1 \\
1 \\
1 \\
1 \\
1 \\
1 \\
1 \\
1 \\
1 \\
1 \\
1 \\
1 \\
1 \\
1 \\
1 \\
1 \\
1 \\
1\end{array}$ & $\begin{array}{r}1 \\
2 \\
1 \\
2 \\
-1 \\
1 \\
2 \\
1 \\
1 \\
1 \\
1 \\
1 \\
1 \\
1 \\
2 \\
1 \\
1 \\
2 \\
1 \\
2 \\
2 \\
2 \\
1 \\
1 \\
2 \\
-1 \\
2 \\
2 \\
2 \\
2 \\
2 \\
1 \\
2 \\
2 \\
2 \\
1 \\
1 \\
2 \\
1 \\
1 \\
1 \\
1 \\
1 \\
2 \\
2 \\
1 \\
2 \\
1 \\
1 \\
1\end{array}$ & $\begin{array}{r}3.67 \\
3.20 \\
3.49 \\
3.69 \\
-1.66 \\
3.96 \\
3.29 \\
3.81 \\
3.48 \\
3.60 \\
3.46 \\
3.61 \\
3.66 \\
3.67 \\
2.76 \\
3.43 \\
3.66 \\
3.38 \\
3.77 \\
3.34 \\
3.69 \\
3.27 \\
3.63 \\
3.69 \\
3.29 \\
-1.66 \\
3.23 \\
3.66 \\
3.46 \\
3.69 \\
3.66 \\
3.64 \\
3.11 \\
3.11 \\
3.39 \\
3.40 \\
3.20 \\
2.94 \\
2.43 \\
3.39 \\
3.37 \\
3.36 \\
3.52 \\
3.63 \\
3.62 \\
3.12 \\
3.16 \\
3.47 \\
3.19 \\
3.32\end{array}$ & 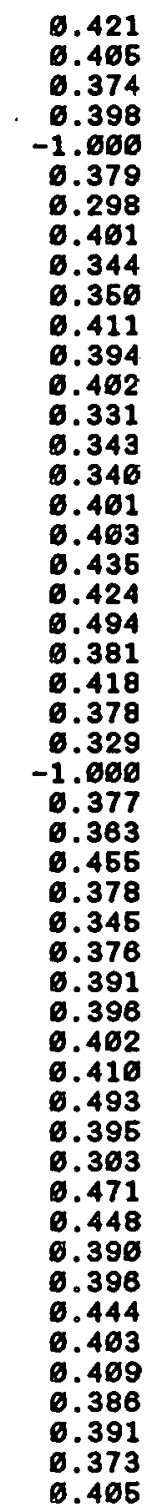 \\
\hline
\end{tabular}

Status: $1=$ Live; $2=\begin{aligned} \text { Early Resorption; } 4=\text { Late Resorption; } 5=\text { Live } \\ \text { Sex: Male }=1 ; \text { Female }=2\end{aligned}$ 


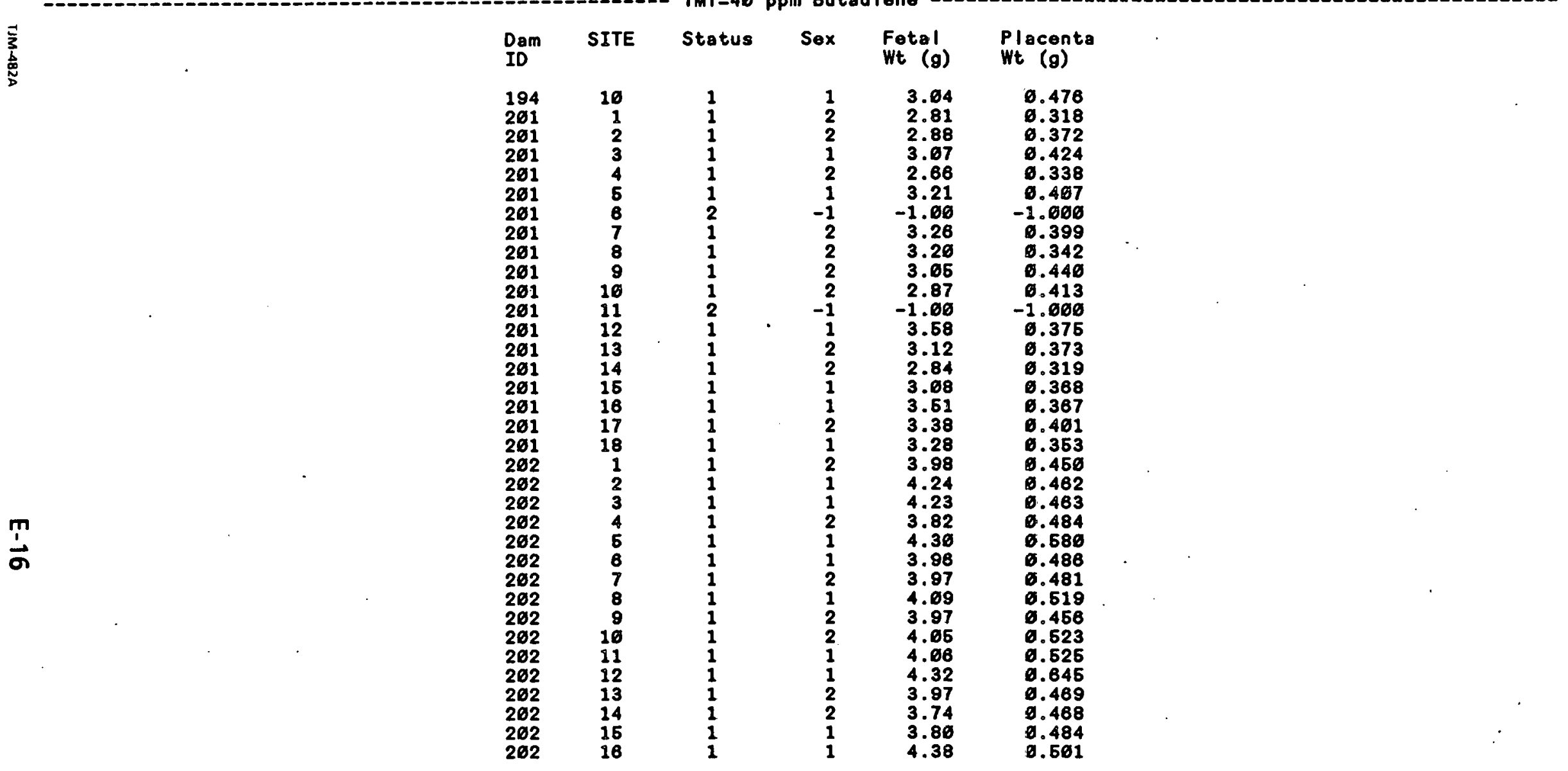


BUTADIENE RAT FETAL DATA

Sex

Fetal

Placenta

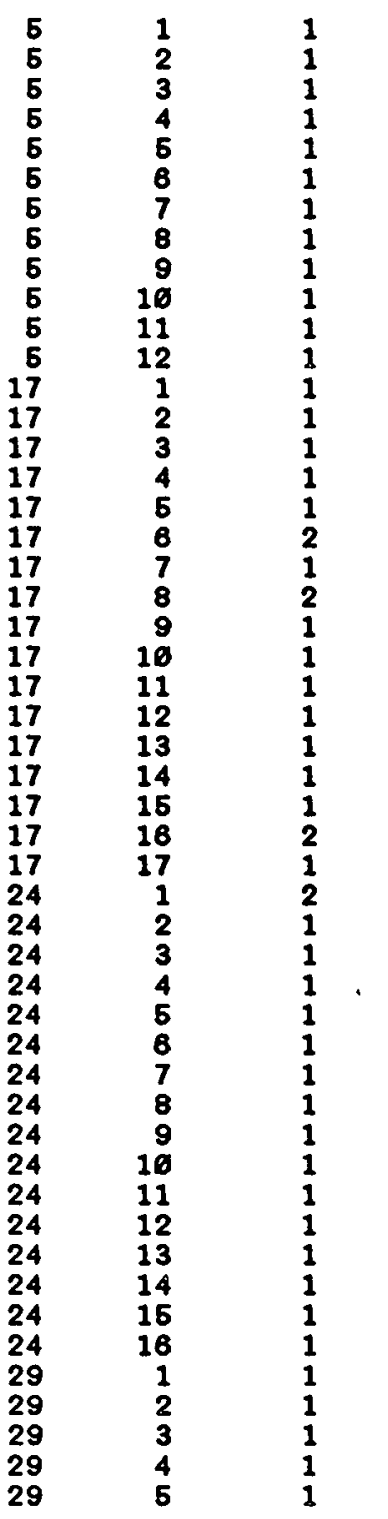

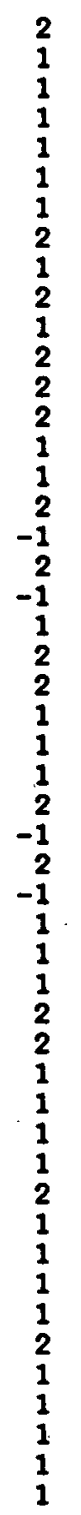

3.39

3.18

3.11

3.35

3.42

3.32
3.37

3.37
2.91

3.22

2.78

3.85

3.17

3.29

3.26

3.50

3.62

3.45

-1.06
2.88

2.88
-1.06

3.61
2.97
2.97

2.97
3.44

3.44
3.58

3.63

$-1.00$

3.47
-1.00

-1.00
3.15

2.91
3.23

3.23

3.61
3.89

3.89

3.15
3.25

3.25
3.36

3.36
2.35

2.35
2.99

3.58

3.42

3.26

3.18

3.73

3.66
3.73

3.73
3.72

ø.343

0.409

0.412

0.449

0.374
$\emptyset .466$

0.379

0.356

0.407

0.448

0.482
0.470

อ. 464

0.444
0.464

0.464

$-1.438$

$-1.606$

$-1.000$

0.461

0.537

0.453

0.490

0.460

0.381

$-1.000$

0.414
-1.909

$-1.00$

0.405

.416

פ. 368

פ.346

ஏ. 378
๖. 519

6.345

D. 652

D.319

0.432

b. 508

D. 412

G. 567

.482

.476

0.478
อ. 598

Status: 1 = Live; $2=\begin{aligned} \text { Early Resorption; } 4=\text { Late Resorption; } 6=\text { Live } & \text { Sex: Male }=1 ; \text { Female }=2\end{aligned}$ 


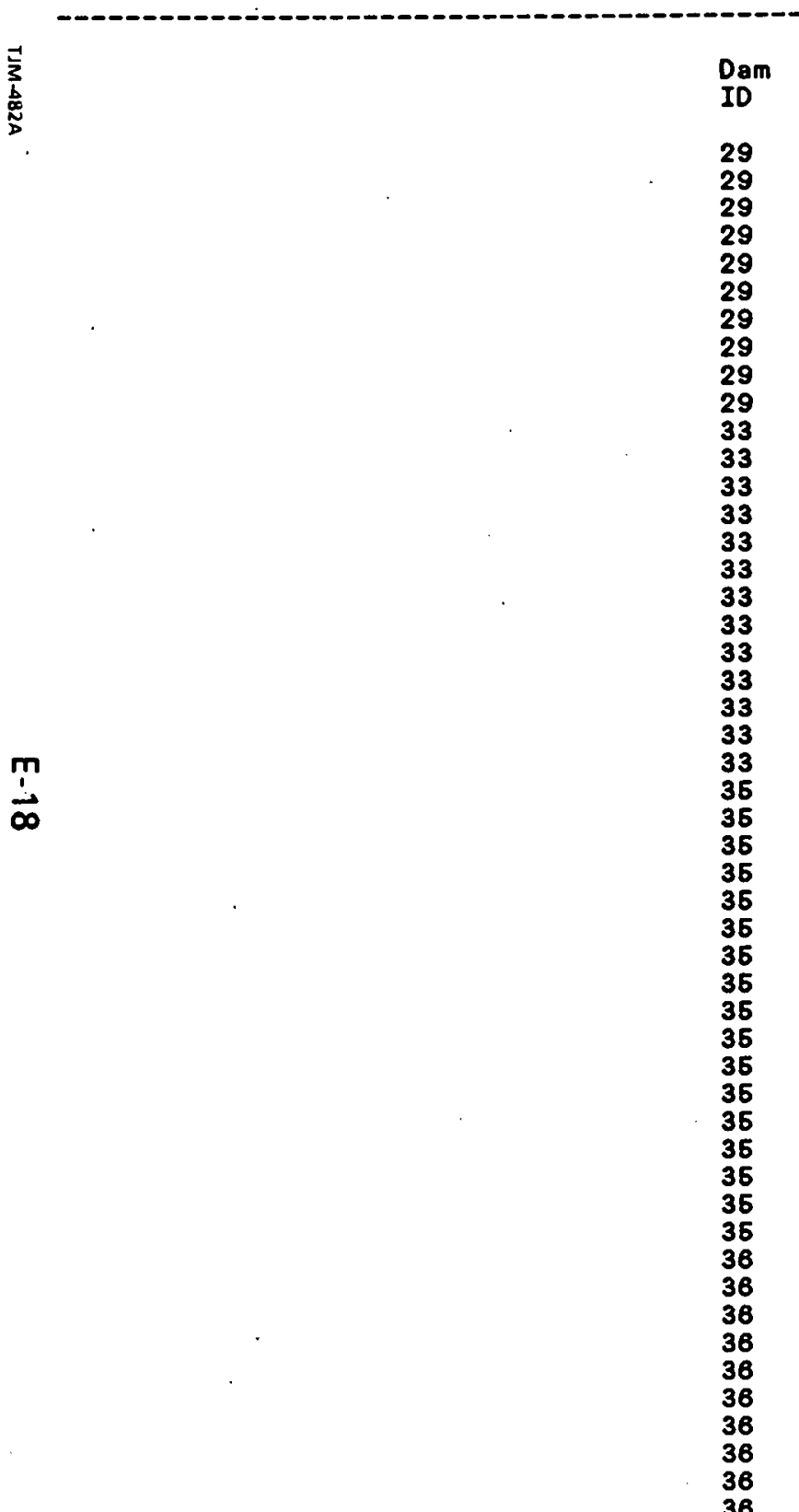

Placento

We (g) Wt (g)

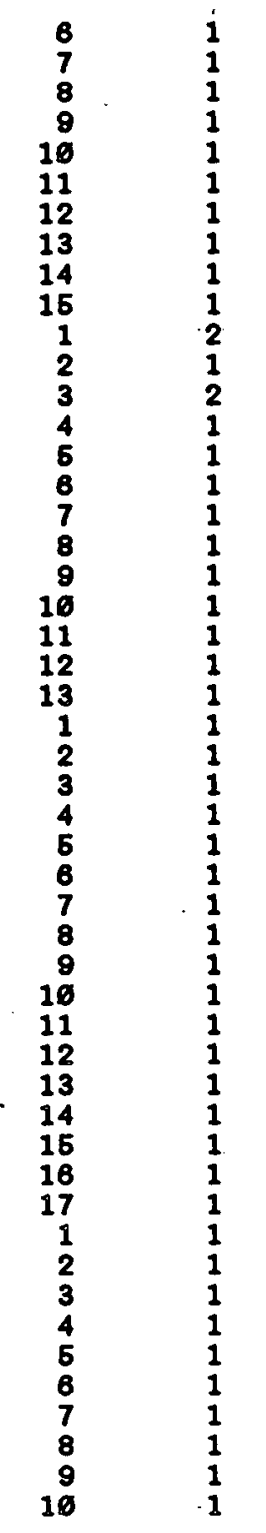

3.91
3.37

3.37
3.29

3.15

3.09

3.09
3.17

3.52

3.61

3.81

3.81
3.82

3.82
-1.50

3.51

$-1.06$

3.55

3.63

3.50
3.81

3.94

3.46

3.68

3.46

3.39
$\mathbf{3} .62$

3.62

3.46

3.44
3.55

3.55
3.45

3.45
3.28

3.66

3.51

3.38

3.53

3.39

2.99

3.62

3.62
3.46
3.23

3.23
3.43

3.45
2.99

2.99
2.82

2.82
3.67

2.99

2.94

2.92

2.83

3.22
3.49

3.49
3.14
0.648

0.611

0.412
0.393

0.629

6.400

0.690

0.457

0.467

$-1.000$

0.410
-1.000

0.470

0.600

0.516
0.457

0.512

0.543

0.481

0.389

0.534

0.483

0.364

0.515

0.419

0.468

0.511

0.421

0.449
0.395

6.385
9.382

0.374

0.423

0.584

0.464

0.676

0.464

0.394

D. 484

0.439

0.438

0.338

0.316

0.398

0.482

Status: 1 = Live; 2 = Early Resorption; 4 = Late Resorption; 5 = Live Sex: Male $=1$; Female $=2$ 


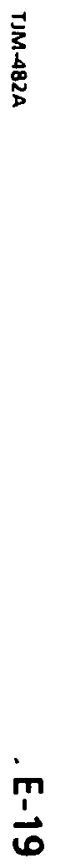

\begin{tabular}{|c|c|c|c|c|c|}
\hline $\begin{array}{l}\text { Dan } \\
\text { ID }\end{array}$ & SITE & Status & Sex & $\begin{array}{l}\text { Fetal } \\
\text { Wt (g) }\end{array}$ & $\begin{array}{l}\text { Placenta } \\
W t \quad(g)\end{array}$ \\
\hline $\begin{array}{l}38 \\
36 \\
36 \\
36 \\
36 \\
36 \\
36 \\
46 \\
46 \\
46 \\
46 \\
46 \\
46 \\
46 \\
46 \\
46 \\
46 \\
46 \\
46 \\
46 \\
46 \\
46 \\
41 \\
41 \\
41 \\
41 \\
41 \\
41 \\
41 \\
41 \\
41 \\
41 \\
41 \\
41 \\
41 \\
48 \\
48 \\
48 \\
48 \\
48 \\
48 \\
48 \\
48 \\
48 \\
48 \\
48 \\
48 \\
48 \\
48 \\
48\end{array}$ & $\begin{array}{r}11 \\
12 \\
13 \\
14 \\
16 \\
18 \\
17 \\
1 \\
2 \\
3 \\
4 \\
5 \\
8 \\
7 \\
8 \\
9 \\
16 \\
11 \\
12 \\
13 \\
14 \\
15 \\
1 \\
2 \\
3 \\
4 \\
5 \\
6 \\
7 \\
8 \\
9 \\
19 \\
11 \\
12 \\
13 \\
1 \\
2 \\
3 \\
4 \\
5 \\
8 \\
7 \\
8 \\
9 \\
16 \\
11 \\
12 \\
13 \\
14 \\
15\end{array}$ & $\begin{array}{l}1 \\
1 \\
1 \\
1 \\
1 \\
1 \\
2 \\
1 \\
1 \\
1 \\
1 \\
1 \\
1 \\
1 \\
1 \\
1 \\
1 \\
1 \\
1 \\
1 \\
1 \\
1 \\
1 \\
2 \\
2 \\
1 \\
1 \\
1 \\
2 \\
1 \\
1 \\
2 \\
2 \\
1 \\
1 \\
1 \\
1 \\
1 \\
1 \\
1 \\
1 \\
1 \\
1 \\
1 \\
1 \\
1 \\
1 \\
2 \\
1 \\
1\end{array}$ & $\begin{array}{r}2 \\
2 \\
1 \\
1 \\
1 \\
1 \\
-1 \\
2 \\
1 \\
1 \\
2 \\
1 \\
2 \\
2 \\
2 \\
2 \\
1 \\
2 \\
2 \\
2 \\
2 \\
2 \\
2 \\
2 \\
-1 \\
-1 \\
1 \\
2 \\
2 \\
-1 \\
2 \\
1 \\
-1 \\
-1 \\
2 \\
2 \\
1 \\
2 \\
2 \\
2 \\
1 \\
1 \\
2 \\
2 \\
2 \\
1 \\
1 \\
1 \\
1 \\
1 \\
-1 \\
2\end{array}$ & 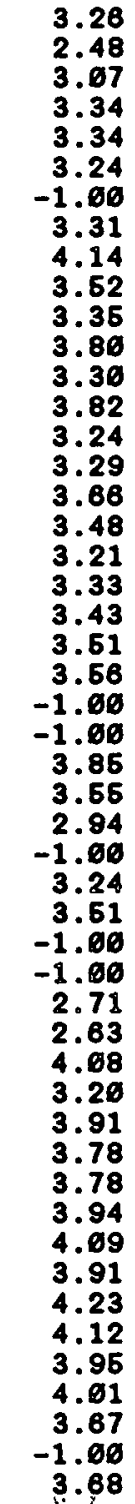 & 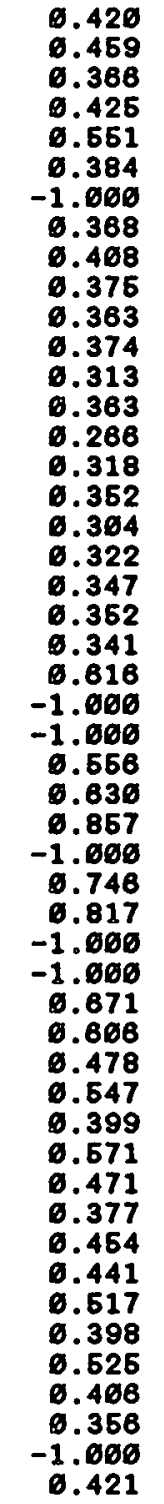 \\
\hline
\end{tabular}

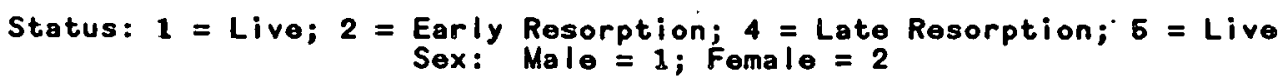




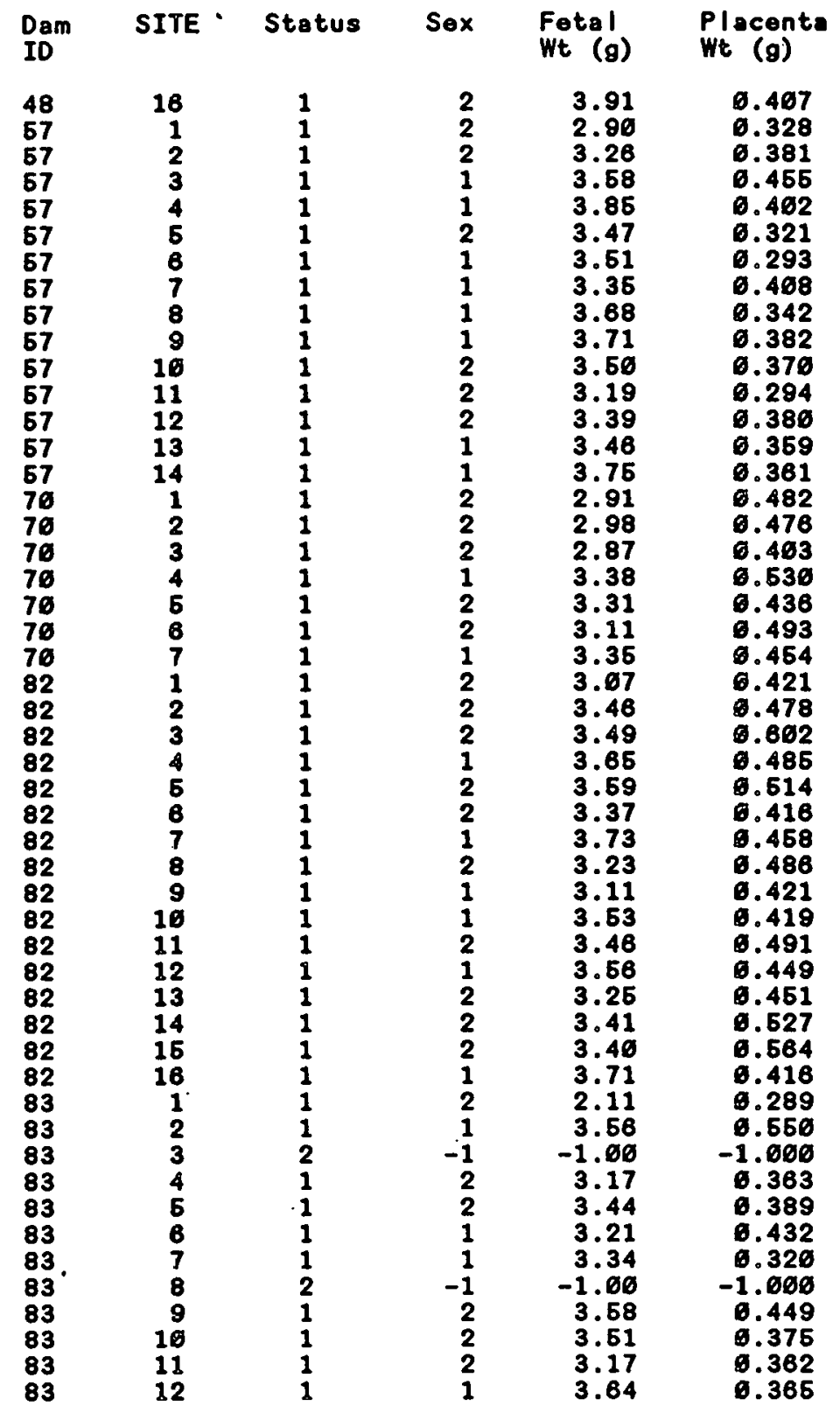

Status: 1 = Live; 2 = Early Resorption; 4 = Late Resorption: 5 = Live Sex: Male $=1$; Female $=2$ 


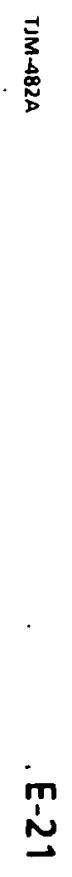

Dam SITE

Status

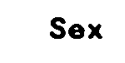

Fotal

Plocenta

83

13
14
15

83

110

110

110

110
110
116

110
110

110

110

110

110

110

110
118

118

118

118
118

118

\begin{tabular}{|c|c|c|c|}
\hline $\begin{array}{l}2 \\
1 \\
1 \\
1 \\
1 \\
1 \\
1 \\
1 \\
1 \\
1 \\
1 \\
1 \\
1 \\
1 \\
1 \\
1 \\
1 \\
1 \\
1 \\
1 \\
1 \\
1 \\
1 \\
1 \\
1 \\
1 \\
1 \\
1 \\
1 \\
2 \\
1 \\
1 \\
1 \\
1 \\
1 \\
1 \\
1 \\
1 \\
1 \\
1 \\
1 \\
2 \\
1 \\
1 \\
1 \\
1 \\
1 \\
2 \\
1\end{array}$ & 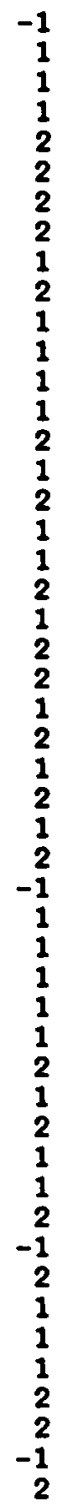 & 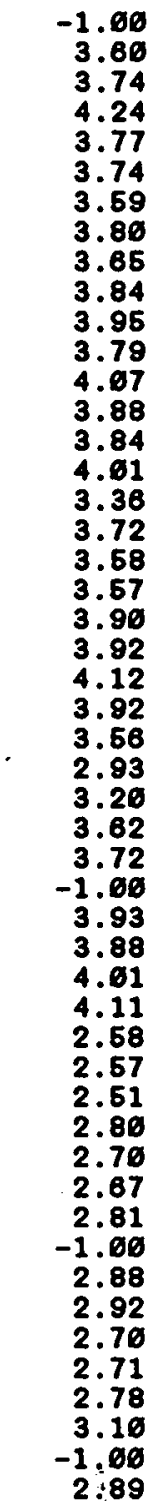 & 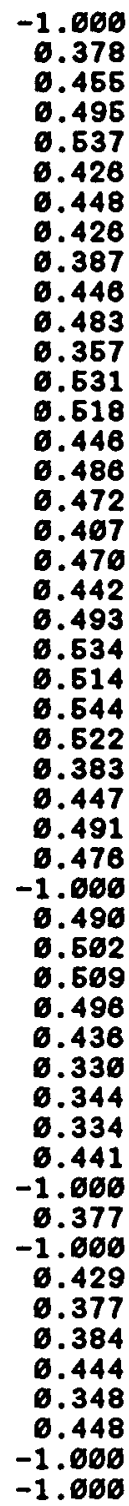 \\
\hline
\end{tabular}

118
118

Status: $1=$ Live; $2=\begin{aligned} & \text { Early Resorption; } 4=\text { Late Resorption; } 6=\text { Live } \\ \text { Sex: Male }=1 ; \text { Female }=2 & \text { L }\end{aligned}$ 
$\stackrel{\text { N }}{\text { ஸ́ }}$

\begin{tabular}{|c|c|c|c|c|c|}
\hline $\begin{array}{l}\text { Dam } \\
\text { ID }\end{array}$ & SITE & Status & Sex & $\begin{array}{l}\text { Fetal } \\
\text { Wt (g) }\end{array}$ & $\begin{array}{l}\text { Placenta } \\
\text { Wt (g) }\end{array}$ \\
\hline $\begin{array}{l}127 \\
127 \\
127 \\
127 \\
127 \\
127 \\
127 \\
127 \\
127 \\
127 \\
127 \\
127 \\
127 \\
127 \\
127 \\
127 \\
127 \\
136 \\
136 \\
136 \\
138 \\
138 \\
136 \\
136 \\
130 \\
136 \\
136 \\
138 \\
138 \\
138 \\
138 \\
136 \\
131 \\
131 \\
131 \\
131 \\
131 \\
131 \\
131 \\
131 \\
131 \\
131 \\
131 \\
131 \\
131 \\
131 \\
131 \\
131 \\
133 \\
133\end{array}$ & $\begin{array}{r}1 \\
2 \\
3 \\
4 \\
5 \\
6 \\
7 \\
8 \\
9 \\
16 \\
11 \\
12 \\
13 \\
14 \\
15 \\
16 \\
17 \\
1 \\
2 \\
3 \\
4 \\
5 \\
6 \\
7 \\
8 \\
9 \\
16 \\
11 \\
12 \\
13 \\
14 \\
15 \\
1 \\
2 \\
3 \\
4 \\
5 \\
6 \\
7 \\
8 \\
9 \\
16 \\
11 \\
12 \\
13 \\
14 \\
16 \\
16 \\
1 \\
2\end{array}$ & $\begin{array}{l}1 \\
1 \\
1 \\
1 \\
1 \\
1 \\
1 \\
1 \\
1 \\
1 \\
1 \\
1 \\
1 \\
1 \\
1 \\
1 \\
1 \\
1 \\
1 \\
1 \\
1 \\
1 \\
1 \\
1 \\
1 \\
1 \\
1 \\
1 \\
1 \\
1 \\
1 \\
1 \\
1 \\
1 \\
1 \\
1 \\
1 \\
1 \\
1 \\
1 \\
1 \\
1 \\
1 \\
1 \\
1 \\
1 \\
1 \\
1 \\
1\end{array}$ & $\begin{array}{l}2 \\
2 \\
1 \\
2 \\
1 \\
2 \\
2 \\
2 \\
2 \\
2 \\
1 \\
2 \\
2 \\
2 \\
2 \\
1 \\
1 \\
1 \\
1 \\
1 \\
1 \\
1 \\
1 \\
1 \\
1 \\
2 \\
2 \\
2 \\
1 \\
2 \\
1 \\
1 \\
2 \\
1 \\
2 \\
2 \\
2 \\
2 \\
2 \\
1 \\
1 \\
1 \\
2 \\
1 \\
2 \\
2 \\
1 \\
2 \\
2 \\
1 \\
2 \\
2 \\
\end{array}$ & $\begin{array}{l}3.24 \\
3.24 \\
3.33 \\
3.16 \\
3.42 \\
3.22 \\
2.87 \\
2.81 \\
3.11 \\
3.19 \\
3.61 \\
3.34 \\
3.10 \\
3.34 \\
3.27 \\
3.67 \\
3.42 \\
3.74 \\
3.87 \\
3.94 \\
3.92 \\
4.69 \\
4.29 \\
4.67 \\
3.60 \\
3.63 \\
3.63 \\
4.61 \\
3.86 \\
4.22 \\
4.29 \\
3.68 \\
2.85 \\
3.05 \\
3.28 \\
2.68 \\
2.88 \\
3.37 \\
3.67 \\
2.94 \\
2.83 \\
2.87 \\
2.85 \\
2.72 \\
3.36 \\
3.65 \\
2.74 \\
2.86 \\
3.63 \\
3.69\end{array}$ & 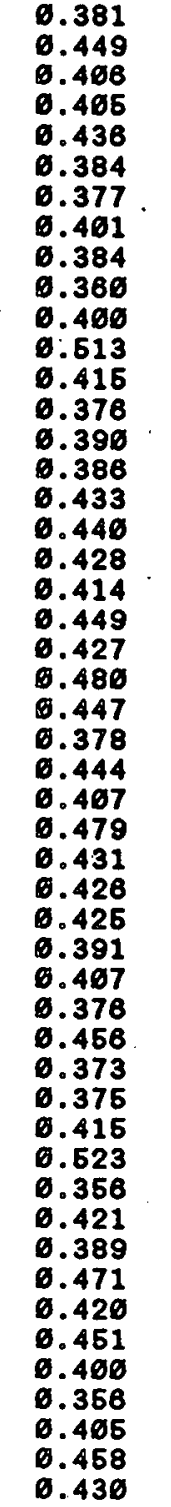 \\
\hline
\end{tabular}




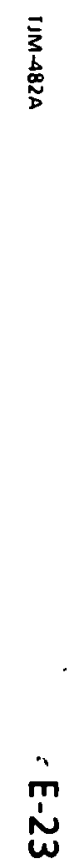$$
\text { Dam SITE }
$$$$
\text { Status }
$$

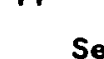

Sex

Fetal

Placenta

133

133
133

133
133

133
133

133
133

133

133

133
133

133
133

133

133

133

133

133

146

146

140

140

140

148

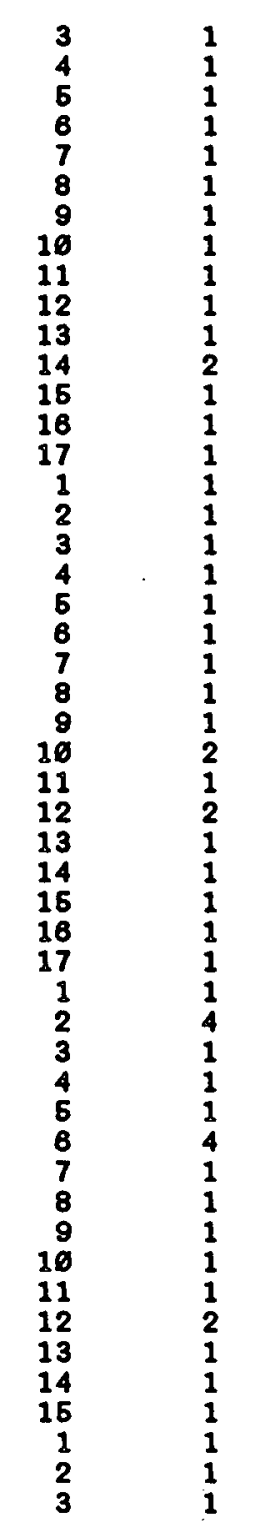

3.47

3.47
3.26

g. 589

3.37

3.37
3.26

3.18
3.41

3.41
3.29

3.29
3.22

3.22
3.09

3.24

$-1.00$

3.23

3.11

3.12

3.64

3.84
3.54
3.59

3.56
3.68

3.56
3.74

3.74
3.45
3.39

3.39
3.50

3.60
-1.06

$-1.06$

3.86
-1.00

-1.06
3.61

3.48

3.41

3.00

3.47
3.47

$-1.06$

3.42
3.67

3.67
3.60

3.60
-1.60

3.39

3.38

3.68

3.84

3.60
-1.99

-1.08
3.53

3.67

3.67
3.81
3.38

3.36
, 3.49

6.441
0.576

0.477

0.424

0.422

0.469

0.463

0.560

g. 424

0.420
-1.000

$-1.000$

$-1.000$

6.450

9.358

0.392
0.443

0.443
6.372

6.425

๑. 466

6.425

0.417

$-1.000$

0.558
-1.098

$-1.060$

6.514

8.464

8.333

0.332

$-1.090$

$-1.000$

0.397

0.373

$-1.860$

. 399

0.417

0.317

0.414

$-1.000$

פ. 288

פ. 353

0.414

0.402

Status: 1 = Live; 2 = Early Resorption; 4 = Late Resorption; 5 = Live

Sex: Male = 1; Female = 2 
BUTADIENE RAT FETAL DATA

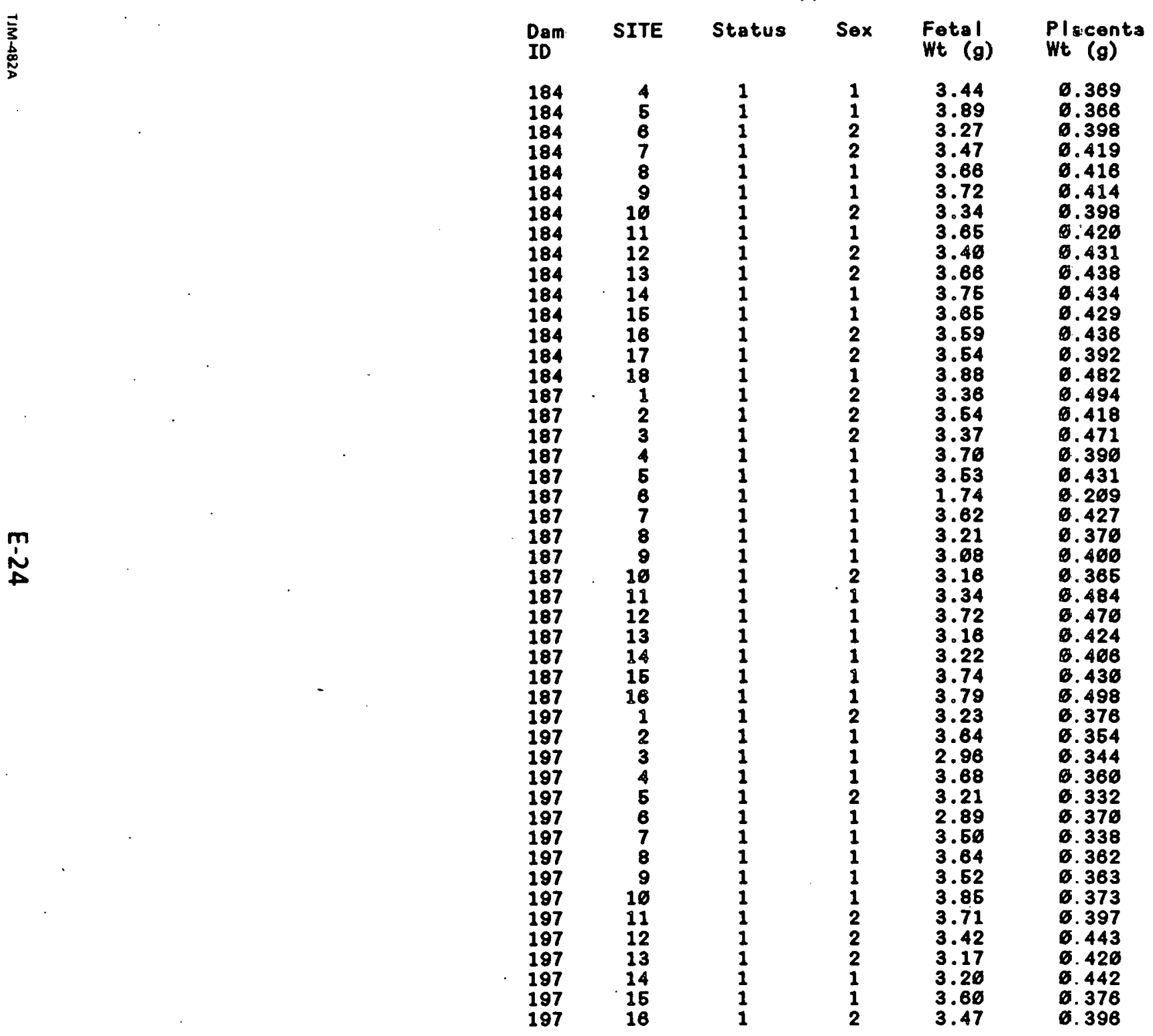




\begin{tabular}{|c|c|c|c|c|c|}
\hline $\begin{array}{l}\text { Dam } \\
\text { ID }\end{array}$ & SITE & Status & Sex & $\begin{array}{l}\text { Fetal } \\
\text { Wt (g) }\end{array}$ & $\begin{array}{l}\text { Placenta } \\
\text { Wt }(g)\end{array}$ \\
\hline $\begin{array}{l}1 \\
1 \\
1 \\
1 \\
1 \\
1 \\
1 \\
1 \\
1 \\
1 \\
1 \\
1 \\
1 \\
1 \\
1 \\
1 \\
15 \\
15 \\
15 \\
16 \\
15 \\
15 \\
15 \\
15 \\
15 \\
15 \\
15 \\
15 \\
15 \\
15 \\
15 \\
16 \\
16 \\
16 \\
16 \\
21 \\
21 \\
21 \\
21 \\
21 \\
21 \\
21 \\
21 \\
21 \\
21 \\
21 \\
21 \\
21 \\
21 \\
21\end{array}$ & $\begin{array}{r}1 \\
2 \\
3 \\
4 \\
5 \\
6 \\
7 \\
8 \\
9 \\
16 \\
11 \\
12 \\
13 \\
14 \\
15 \\
16 \\
1 \\
2 \\
3 \\
4 \\
5 \\
8 \\
7 \\
8 \\
9 \\
10 \\
11 \\
12 \\
13 \\
14 \\
15 \\
1 \\
2 \\
3 \\
4 \\
1 \\
2 \\
3 \\
4 \\
5 \\
6 \\
7 \\
8 \\
9 \\
16 \\
11 \\
12 \\
13 \\
14 \\
15\end{array}$ & $\begin{array}{l}1 \\
1 \\
1 \\
1 \\
1 \\
1 \\
1 \\
1 \\
1 \\
1 \\
1 \\
1 \\
1 \\
1 \\
1 \\
1 \\
1 \\
2 \\
1 \\
1 \\
1 \\
1 \\
1 \\
1 \\
1 \\
1 \\
1 \\
1 \\
1 \\
1 \\
1 \\
1 \\
1 \\
1 \\
1 \\
1 \\
1 \\
1 \\
1 \\
1 \\
1 \\
1 \\
1 \\
1 \\
1 \\
1 \\
1 \\
1 \\
1 \\
1\end{array}$ & $\begin{array}{l}2 \\
1 \\
1 \\
1 \\
2 \\
2 \\
1 \\
2 \\
1 \\
1 \\
2 \\
2 \\
1 \\
2 \\
1 \\
1 \\
2 \\
1 \\
2 \\
2 \\
1 \\
1 \\
2 \\
2 \\
2 \\
1 \\
2 \\
2 \\
2 \\
2 \\
1 \\
1 \\
2 \\
1 \\
1 \\
2 \\
1 \\
1 \\
1 \\
2 \\
2 \\
2 \\
2 \\
1 \\
1 \\
1 \\
1 \\
2 \\
2 \\
1\end{array}$ & 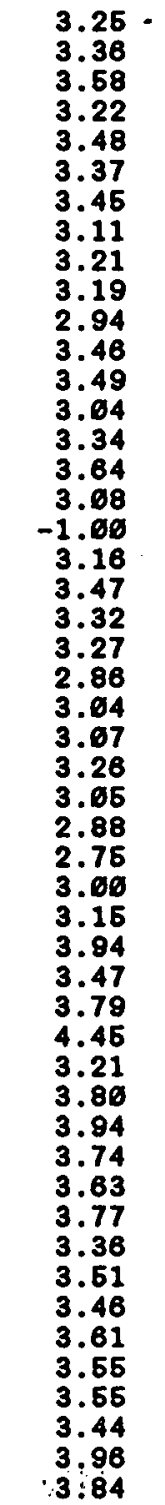 & 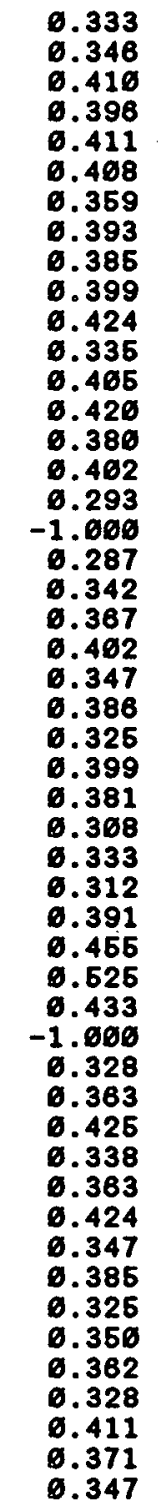 \\
\hline
\end{tabular}

Status: 1 = Live; 2 = Early Resorption; 4 = Lete Resorption; 6 = Live 
BUTADIENE RAT FETAL DATA

TMT=1000 ppm Butadiene

\begin{tabular}{|c|c|c|c|c|c|}
\hline $\begin{array}{l}\text { Dam } \\
\text { ID }\end{array}$ & SITE & Status & Sex & $\begin{array}{l}\text { Fetal } \\
\text { Wt (g) }\end{array}$ & $\begin{array}{l}P l \text { ocent } \\
W t(g)\end{array}$ \\
\hline $\begin{array}{l}21 \\
21 \\
32 \\
32 \\
32 \\
32 \\
32 \\
32 \\
32 \\
32 \\
32 \\
32 \\
32 \\
32 \\
32 \\
32 \\
46 \\
46 \\
46 \\
46 \\
46 \\
46 \\
46 \\
46 \\
46 \\
46 \\
46 \\
46 \\
46 \\
46 \\
46 \\
46 \\
47 \\
47 \\
47 \\
47 \\
47 \\
47 \\
47 \\
47 \\
47 \\
47 \\
47 \\
47 \\
47 \\
47 \\
52 \\
62 \\
52 \\
62\end{array}$ & $\begin{array}{r}16 \\
17 \\
1 \\
2 \\
3 \\
4 \\
5 \\
6 \\
7 \\
8 \\
9 \\
10 \\
11 \\
12 \\
13 \\
14 \\
1 \\
2 \\
3 \\
4 \\
5 \\
6 \\
7 \\
8 \\
9 \\
10 \\
11 \\
12 \\
13 \\
14 \\
15 \\
16 \\
1 \\
2 \\
3 \\
4 \\
5 \\
6 \\
7 \\
8 \\
9 \\
16 \\
11 \\
12 \\
13 \\
14 \\
1 \\
2 \\
3 \\
4\end{array}$ & $\begin{array}{l}1 \\
1 \\
1 \\
1 \\
1 \\
1 \\
1 \\
1 \\
1 \\
1 \\
1 \\
1 \\
1 \\
1 \\
1 \\
1 \\
1 \\
1 \\
1 \\
1 \\
1 \\
1 \\
1 \\
1 \\
1 \\
1 \\
1 \\
1 \\
1 \\
1 \\
1 \\
1 \\
1 \\
1 \\
1 \\
1 \\
1 \\
1 \\
1 \\
2 \\
1 \\
1 \\
1 \\
1 \\
1 \\
1 \\
1 \\
1 \\
1 \\
1\end{array}$ & $\begin{array}{r}2 \\
1 \\
1 \\
2 \\
2 \\
2 \\
1 \\
1 \\
1 \\
1 \\
2 \\
1 \\
2 \\
2 \\
2 \\
2 \\
2 \\
1 \\
1 \\
1 \\
1 \\
1 \\
1 \\
2 \\
2 \\
2 \\
2 \\
1 \\
1 \\
2 \\
1 \\
1 \\
1 \\
2 \\
1 \\
1 \\
1 \\
2 \\
1 \\
-1 \\
1 \\
1 \\
1 \\
1 \\
1 \\
2 \\
1 \\
2 \\
2 \\
2\end{array}$ & $\begin{array}{r}3.22 \\
3.91 \\
3.76 \\
3.22 \\
3.39 \\
3.46 \\
3.58 \\
3.65 \\
3.76 \\
3.76 \\
3.58 \\
1.98 \\
3.69 \\
3.49 \\
3.47 \\
3.88 \\
3.98 \\
3.88 \\
4.39 \\
4.62 \\
4.16 \\
4.21 \\
4.21 \\
4.67 \\
3.82 \\
3.61 \\
3.86 \\
4.83 \\
4.66 \\
4.65 \\
4.20 \\
4.14 \\
4.44 \\
4.12 \\
4.84 \\
4.22 \\
3.93 \\
4.16 \\
4.33 \\
-1.06 \\
4.32 \\
4.32 \\
4.17 \\
4.24 \\
4.23 \\
3.96 \\
3.49 \\
3.46 \\
3.46 \\
3.44\end{array}$ & 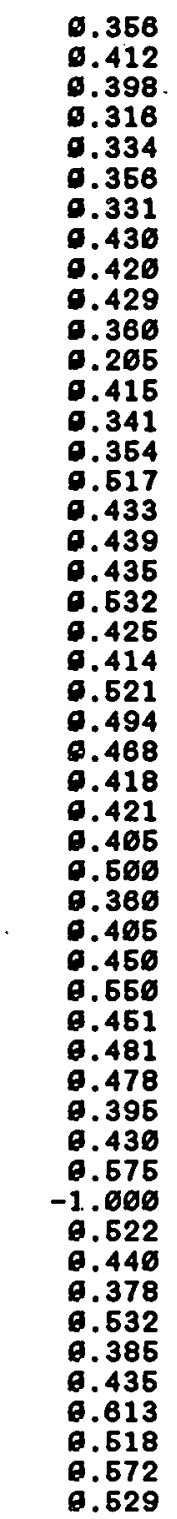 \\
\hline
\end{tabular}

Status: 1 = Live; 2 = Early Resorption; 4 = Lote Resorption: 6 = Live 
TMT=10ळळ ppm Butadiene

Placenta

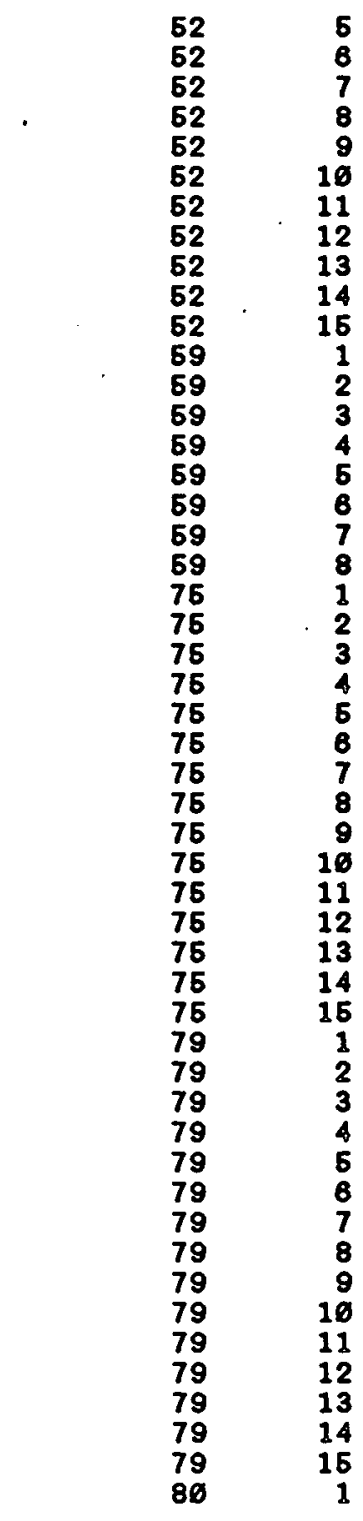

$$
\begin{aligned}
& 1 \\
& 1 \\
& 1 \\
& 1 \\
& 1 \\
& 1 \\
& 1 \\
& 2 \\
& 1 \\
& 1 \\
& 1 \\
& 1 \\
& 1 \\
& 1 \\
& 1 \\
& 1 \\
& 1 \\
& 1 \\
& 1 \\
& 1 \\
& 1 \\
& 1 \\
& 1 \\
& 1 \\
& 1 \\
& 2 \\
& 1 \\
& 1 \\
& 1 \\
& 1 \\
& 1 \\
& 1 \\
& 1 \\
& 1 \\
& 1 \\
& 1 \\
& 1 \\
& 1 \\
& 1 \\
& 1 \\
& 1 \\
& 1 \\
& 1 \\
& 1 \\
& 1 \\
& 1 \\
& 1 \\
& 1 \\
& 1 \\
& 1 \\
& 1 \\
& 1
\end{aligned}
$$

3.58

3.36

\section{ต. 568}

0.482
6.608

$3.56 \quad 0.569$

$3.32 \quad 0.496$

$3.57 \quad 0.536$

$\begin{array}{rr}-1.06 & -1.008 \\ 3.85 & 0.478\end{array}$

$3.36 \quad 0.468$

$3.74 \quad 0.464$

$3.83 \quad 0.423$

$4.62 \quad 0.520$

$4.20 \quad 9.654$

$4.23 \quad 0.517$

$3.80 \quad 9.615$

$4.01 \quad 0.567$

$4.24 \quad 0.661$

4.170 .600

$2.91 \quad 0.466$

$2.82 \quad 0.384$

$3.14 \quad 0.394$

$3.20 \quad 0.389$

$-1.00 \quad-1.000$

$3.09 \quad 0.383$

$3.22 \quad 0.498$

$3.64 \quad-1.000$

$2.91 \quad 0.371$

2.83

$3.69 \quad 0.424$

$3.00 \quad 0.398$

2.910 .485

$3.12 \quad 0.393$

$3.28 \quad 0.487$

$3.36 \quad 0.339$

$3.20 \quad 0.330$

$4.87 \quad 0.430$

$3.12 \quad 0.430$

$3.64 \quad 0.410$

$2.39 \quad 0.467$

$3.81 \quad 6.420$

$3.36 \quad 0.492$

0.332

$3.41 \quad 6.389$

$3.38 \quad 0.378$

$\begin{array}{ll}3.20 & 0.394 \\ 3.79 & 0.366\end{array}$

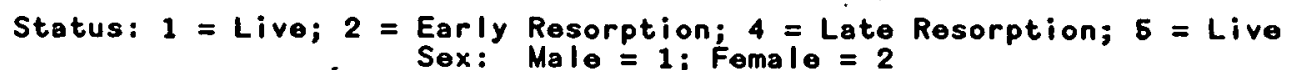




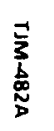$$
\text { Dam SITE }
$$$$
\text { Status }
$$$$
\text { Sex }
$$

Fotal

Wt (g)

3.46

3.75

3.78

3.91

3.61

3.83

3.81

3.32

3.95

$-1.00$

4.68

3.76

3.80
2.99

2.99
3.32

3.28

3.26

3.19

3.10
-1.00

2.90

3.24

$-1.00$

-1.06
3.15

3.32

3.39
3.70

3.71
$\mathbf{3} .57$

3.57
3.65

3.65
-1.00

-1.00
3.48

3.31

3.46

3.84
2.95

3.45

3.79

-1.00
-1.00

$-1.00$

3.00

3.12
2.73

2.73
3.76

3.16

3.54
3.53

3.59
Placenta

Wt (g)

\section{432}

0.367

0.444

8.364

0.419

9.454

6.410

0.318

0.428
-1.908

-1.000
0.342

g. 462

. 398

. .398

.386

0.489
0.429

0.461

0.385

0.449

$-1.000$

8.436

8.439
-1.989

-1.000
0.465

8.418

0.489

0.448

0.473

0.471

0.489

$-1.008$

0.443

0.417

0.431

0.423

0.496

0.637

0.442

$-1.000$

$-1.060$

$-1.018$

0.418
0.311

0.311

0.443
0.483

0. 369

0. 499

Q. 364

8.304

Status: 1 = Live; 2 = Early Resorption; 4 = Late Resorption; 15 = Live

Sex: Male $=1$; Female $=2$ 


\begin{tabular}{|c|c|c|c|c|c|}
\hline $\begin{array}{l}\text { Dam } \\
\text { ID }\end{array}$ & SITE & Status & Sex & $\begin{array}{l}\text { Fotal } \\
W t \quad(g)\end{array}$ & $\begin{array}{l}\text { Placenta } \\
W t(g)\end{array}$ \\
\hline $\begin{array}{l}169 \\
109 \\
109 \\
199 \\
109 \\
169 \\
199 \\
169 \\
109 \\
126 \\
126 \\
126 \\
126 \\
126 \\
126 \\
126 \\
126 \\
126 \\
128 \\
126 \\
126 \\
126 \\
126 \\
128 \\
128 \\
128 \\
136 \\
136 \\
136 \\
136 \\
136 \\
136 \\
136 \\
136 \\
136 \\
136 \\
136 \\
136 \\
136 \\
136 \\
136 \\
146 \\
146 \\
146 \\
146 \\
146 \\
146 \\
146 \\
146 \\
146\end{array}$ & $\begin{array}{r}12 \\
13 \\
14 \\
15 \\
16 \\
17 \\
18 \\
19 \\
26 \\
1 \\
2 \\
3 \\
4 \\
5 \\
6 \\
7 \\
8 \\
8 \\
16 \\
11 \\
12 \\
13 \\
14 \\
16 \\
16 \\
17 \\
1 \\
2 \\
3 \\
4 \\
5 \\
6 \\
7 \\
8 \\
9 \\
16 \\
11 \\
12 \\
13 \\
14 \\
15 \\
1 \\
2 \\
3 \\
4 \\
5 \\
6 \\
7 \\
8 \\
9\end{array}$ & $\begin{array}{l}1 \\
1 \\
1 \\
1 \\
1 \\
1 \\
1 \\
1 \\
1 \\
1 \\
1 \\
1 \\
1 \\
2 \\
1 \\
1 \\
1 \\
1 \\
1 \\
1 \\
1 \\
1 \\
1 \\
1 \\
1 \\
1 \\
1 \\
1 \\
1 \\
1 \\
1 \\
1 \\
1 \\
1 \\
1 \\
1 \\
1 \\
1 \\
1 \\
1 \\
1 \\
1 \\
1 \\
1 \\
1 \\
1 \\
1 \\
1 \\
1 \\
1 \\
1 \\
1\end{array}$ & $\begin{array}{r}2 \\
2 \\
2 \\
2 \\
1 \\
1 \\
1 \\
1 \\
1 \\
1 \\
1 \\
1 \\
1 \\
-1 \\
2 \\
1 \\
2 \\
1 \\
1 \\
1 \\
2 \\
2 \\
2 \\
2 \\
2 \\
1 \\
1 \\
2 \\
1 \\
1 \\
2 \\
1 \\
1 \\
1 \\
1 \\
2 \\
1 \\
1 \\
2 \\
1 \\
1 \\
2 \\
1 \\
1 \\
2 \\
1 \\
2 \\
1 \\
1 \\
1\end{array}$ & $\begin{array}{r}3.19 \\
3.13 \\
3.66 \\
3.66 \\
3.41 \\
3.29 \\
3.28 \\
3.65 \\
3.34 \\
2.97 \\
3.36 \\
3.72 \\
3.27 \\
-1.60 \\
3.16 \\
3.57 \\
3.66 \\
3.23 \\
3.43 \\
3.33 \\
3.40 \\
3.17 \\
3.27 \\
3.42 \\
3.26 \\
3.32 \\
3.63 \\
3.27 \\
3.76 \\
3.63 \\
3.39 \\
3.77 \\
3.62 \\
3.38 \\
3.62 \\
3.34 \\
3.49 \\
3.56 \\
3.65 \\
3.77 \\
3.92 \\
3.68 \\
3.48 \\
3.76 \\
3.24 \\
3.94 \\
3.44 \\
3.36 \\
3.37 \\
3.59\end{array}$ & 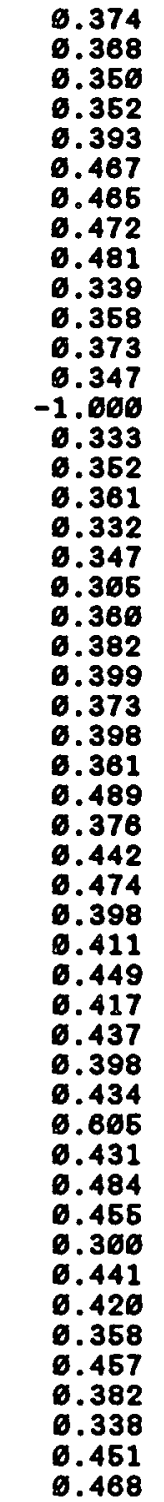 \\
\hline
\end{tabular}

Status: 1 = Live; 2 = Early Resorption; 4 = Late Resorption; 5 = Live Sex: Male $=1$; Female $=2$ 
BUTADIENE RAT FETAL DATA

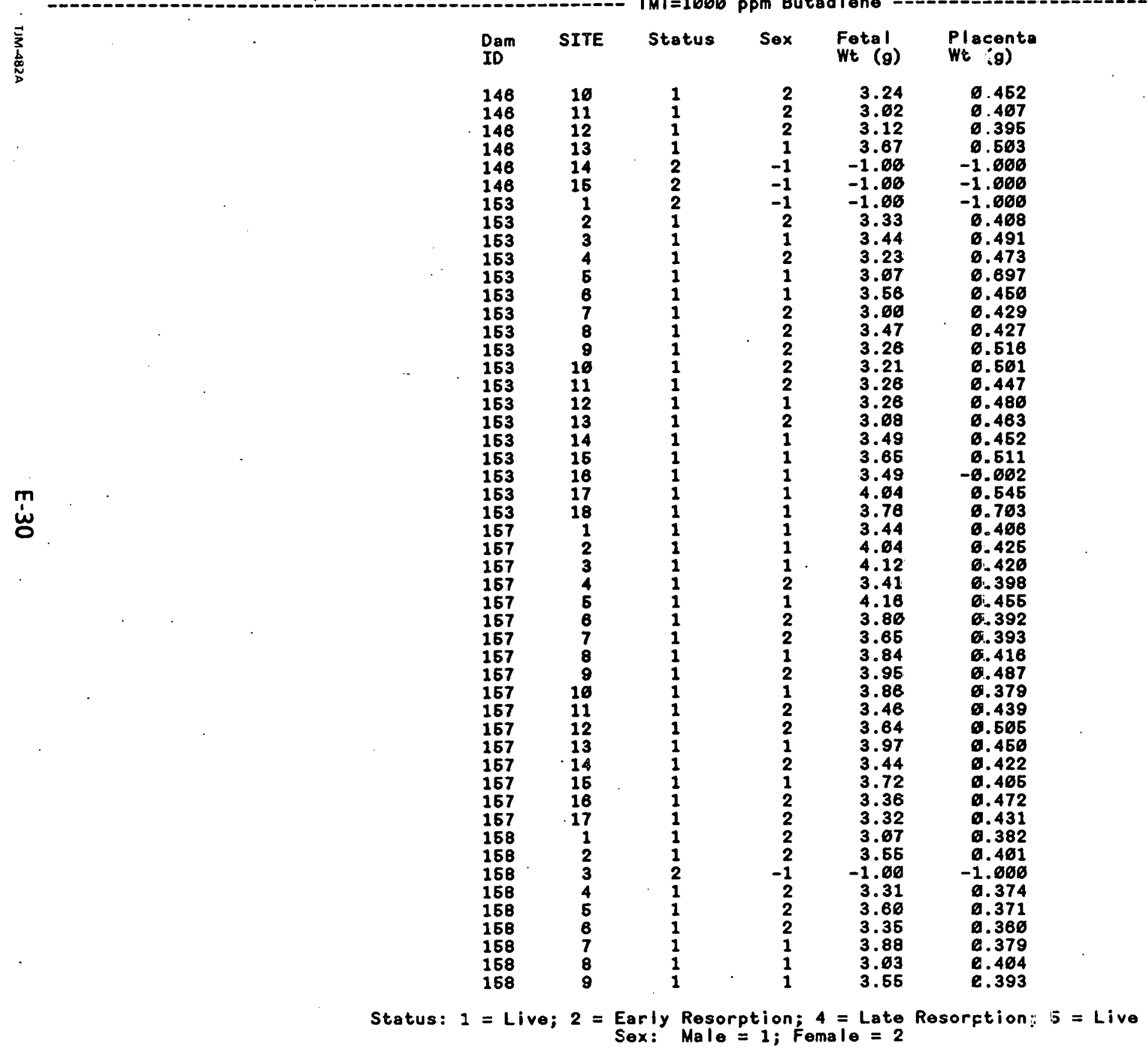



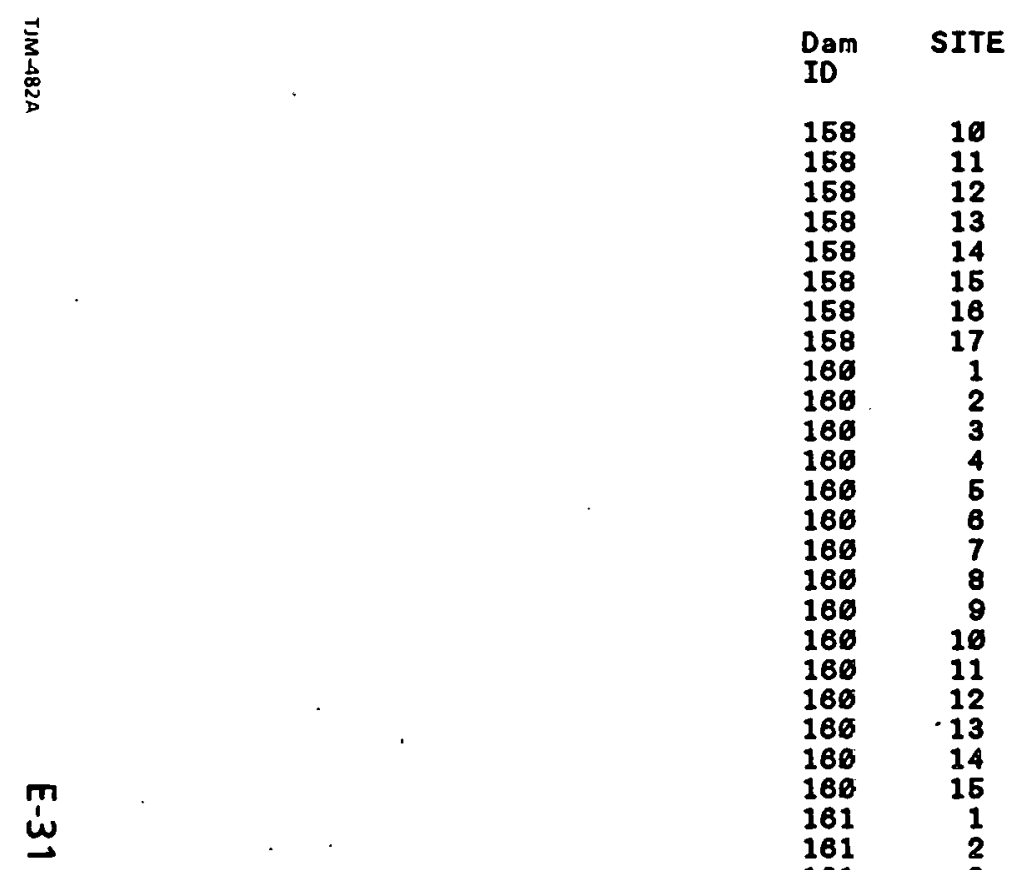

Status

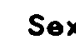

Fotal

Placento

$168 \quad 10$

$\begin{array}{ll}158 & 10 \\ 158 & 11\end{array}$

168

168

158
158

158
158
168

168

160

160

160

160

160

160

160

160

160

160

160

180

168

168

181

181

181

161

161

161

161

161

161

161

161

161

161
161

161

161

161

161 18

177
177

177

177

177

177
177
177
177

177
177

18
11
12
13
14
15
16
17
1
2
3
4
5
6
7
8
9
16
11
12
13
14
15
1
2
3
4
5
6
7
8
9
16
11
12
13
14
15
16
17
18
19
1
2
3
4
6
6
7
8

1
1
1
1
4
1
1
1
1
1
1
1
1
1
1
1
1
1
1
1
1
1
1
1
1
1
1
1
1
1
1
1
1
2
1
1
1
1
1
1
1
1
1
1
1
1
1
1
1

$\begin{array}{r}2 \\ 1 \\ 2 \\ 2 \\ -1 \\ 2 \\ 2 \\ 1 \\ 1 \\ 2 \\ 2 \\ 2 \\ 2 \\ 1 \\ 2 \\ 2 \\ 1 \\ 2 \\ 2 \\ 2 \\ 1 \\ 1 \\ 2 \\ 2 \\ 1 \\ 1 \\ 1 \\ 2 \\ 1 \\ 1 \\ 1 \\ 1 \\ -1 \\ 2 \\ 2 \\ 1 \\ 1 \\ 1 \\ 2 \\ 2 \\ 2 \\ 1 \\ 2 \\ 1 \\ 1 \\ 1 \\ 2 \\ 1 \\ 1 \\ 1 \\ \\ \hline\end{array}$

3.68

Wt (g)

0.06

3.83

$-1.06$

3.43
3.41

3.36

4.03
3.77

3.77
3.44

3.40

4.65

3.57

3.66

3.81

4.14
3.77

3.77
3.88

3.69

3.98

3.74
3.77

3.77
3.58

3.68
3.71

3.56

3.67

3.35

3.65

3.56

3.69

3.84

3.68

$-1.00$

3.49
3.46

3.46
3.88

3.80

3.23

3.62

3.91

3.91
4.17

3.69

3.34

3.55

3.44
2.98

2.98
3.51
3.31

3.31
3.78

0.381

0.484

-1.060
-601

0.321

6.464

0.463

0.359

0.466
0.394

0.336

0.463

0.442

9.433

9.455

0.385

0.428

0.363

0.382

.391

0.397

0.451

0.474

0.415

0.430

0.446

0.431

. 367

6.461

$-1.006$

. 369

0.398

.

0.477

0.528

0.441

0.472

9.299

0.398

0.483

0.343

0.381

$\emptyset .459$

Status: 1 = Live; 2 = Early Resorption; $4=$ Late Resorption; $6=$ Live 


\begin{tabular}{|c|c|c|c|c|c|}
\hline $\begin{array}{l}\text { Dam } \\
\text { ID }\end{array}$ & SITE & Stotus & Sex & $\begin{array}{l}\text { Fotal } \\
\text { Wt (g) }\end{array}$ & $\begin{array}{l}\text { P l acenta } \\
W t \quad(g)\end{array}$ \\
\hline $\begin{array}{l}177 \\
177 \\
177 \\
177 \\
177 \\
177 \\
179 \\
179 \\
179 \\
179 \\
179 \\
179 \\
179 \\
179 \\
179 \\
179 \\
179 \\
179 \\
179 \\
179 \\
188 \\
188 \\
188 \\
188 \\
188 \\
188 \\
188 \\
188 \\
188 \\
188 \\
188 \\
188 \\
188 \\
188 \\
188 \\
188 \\
196 \\
196 \\
196 \\
196 \\
196 \\
196 \\
196 \\
196 \\
196 \\
196 \\
196 \\
196 \\
196 \\
196\end{array}$ & $\begin{array}{r}9 \\
10 \\
11 \\
12 \\
13 \\
14 \\
1 \\
2 \\
3 \\
4 \\
5 \\
6 \\
7 \\
8 \\
9 \\
10 \\
11 \\
12 \\
13 \\
14 \\
1 \\
2 \\
3 \\
4 \\
5 \\
6 \\
7 \\
8 \\
9 \\
16 \\
11 \\
12 \\
13 \\
14 \\
16 \\
16 \\
1 \\
2 \\
3 \\
4 \\
6 \\
6 \\
7 \\
8 \\
9 \\
10 \\
11 \\
12 \\
13 \\
14\end{array}$ & $\begin{array}{l}1 \\
1 \\
1 \\
1 \\
1 \\
1 \\
1 \\
1 \\
1 \\
2 \\
1 \\
1 \\
1 \\
1 \\
1 \\
1 \\
1 \\
1 \\
1 \\
1 \\
1 \\
1 \\
1 \\
1 \\
1 \\
1 \\
1 \\
1 \\
1 \\
1 \\
1 \\
4 \\
1 \\
1 \\
1 \\
1 \\
1 \\
1 \\
1 \\
1 \\
1 \\
1 \\
1 \\
1 \\
1 \\
1 \\
1 \\
1 \\
1 \\
1\end{array}$ & $\begin{array}{r}2 \\
1 \\
2 \\
2 \\
1 \\
1 \\
1 \\
2 \\
2 \\
-1 \\
1 \\
2 \\
1 \\
2 \\
2 \\
2 \\
2 \\
1 \\
1 \\
2 \\
1 \\
1 \\
1 \\
2 \\
1 \\
1 \\
2 \\
2 \\
2 \\
2 \\
1 \\
1 \\
-1 \\
1 \\
2 \\
2 \\
2 \\
2 \\
2 \\
1 \\
1 \\
2 \\
1 \\
1 \\
1 \\
2 \\
2 \\
1 \\
2 \\
2 \\
1 \\
2 \\
\end{array}$ & 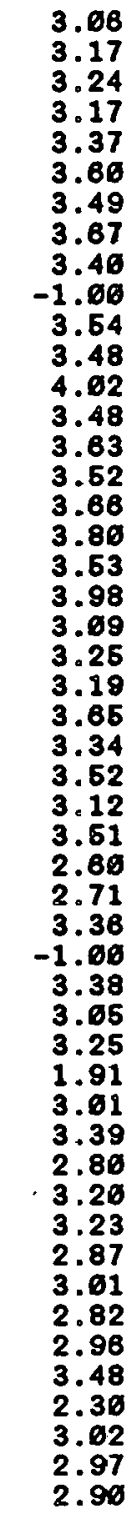 & 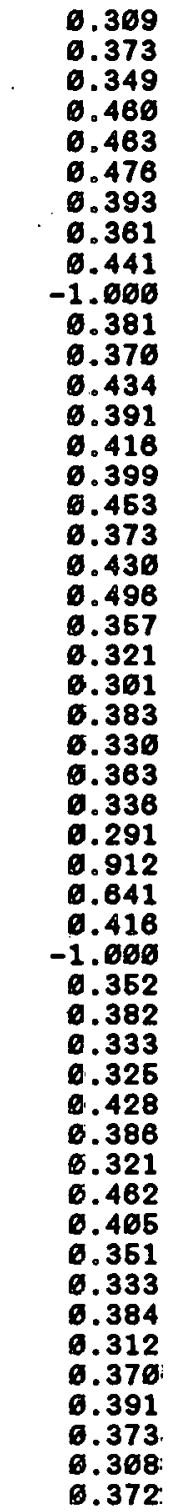 \\
\hline
\end{tabular}

Status: 1 = Live; 2 = Early Resorption; 4 = Late Resorption; 6 = Live 


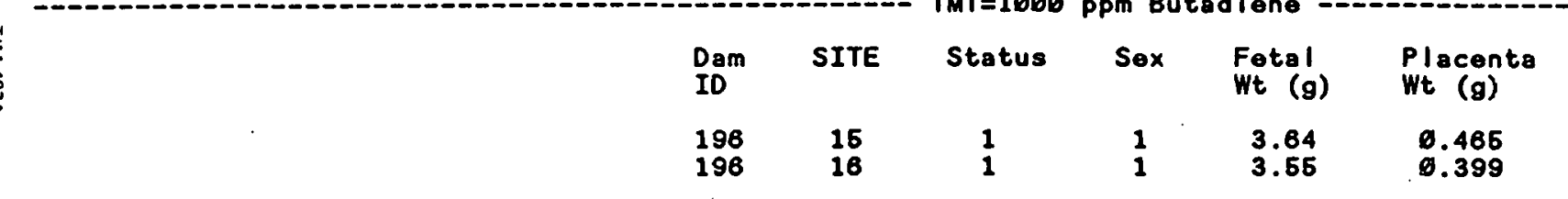

$\stackrel{m}{\dot{m}}$

$\omega$ 


\section{APPENDIXF}

INDIVIDUAL MATERNAL BODY AND UTERINE WEIGHTS 


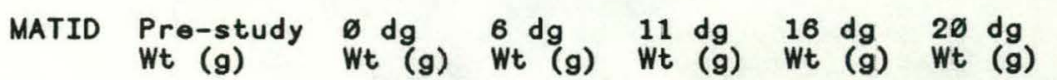

\begin{tabular}{|c|c|c|c|c|c|c|c|c|c|c|c|c|c|c|c|}
\hline $\begin{array}{r}3 \\
11 \\
22 \\
28 \\
3 \emptyset \\
51 \\
61 \\
66 \\
68 \\
85 \\
92 \\
95 \\
98 \\
164 \\
115 \\
121 \\
122 \\
123 \\
124 \\
128 \\
151 \\
156 \\
162 \\
165 \\
17 \emptyset \\
173 \\
176 \\
18 \emptyset \\
181 \\
19 \emptyset\end{array}$ & $\begin{array}{l}257.6 \\
224.8 \\
221.4 \\
254.2 \\
212.2 \\
218.4 \\
230 . \varnothing \\
214.8 \\
217.8 \\
266.4 \\
266.6 \\
246 . \varnothing \\
234 . \varnothing \\
228.8 \\
236 . \varnothing \\
242 . \varnothing \\
261.2 \\
252.4 \\
222.2 \\
235.8 \\
246.4 \\
248.6 \\
224.8 \\
197.4 \\
244.4 \\
213.4 \\
220.4 \\
229.6 \\
234.8 \\
236 . \varnothing\end{array}$ & $\begin{array}{l}277 . \emptyset \\
233.8 \\
221 . \varnothing \\
255 . \varnothing \\
211.2 \\
221.4 \\
235.2 \\
222.8 \\
239.2 \\
266.4 \\
271.8 \\
246.2 \\
231.8 \\
243.4 \\
257.2 \\
252 . \emptyset \\
272.2 \\
261 . \emptyset \\
227 . \emptyset \\
247.4 \\
25 \emptyset .4 \\
241.6 \\
226.6 \\
2 ø 1.4 \\
253.4 \\
213.4 \\
224.4 \\
231.4 \\
242.6 \\
248.2\end{array}$ & $\begin{array}{l}290.2 \\
250 . \varnothing \\
232.2 \\
286.4 \\
222.8 \\
237.2 \\
261.6 \\
248.2 \\
252.4 \\
289.6 \\
291 . \varnothing \\
28 \emptyset . \emptyset \\
252.8 \\
275.2 \\
288.2 \\
272.8 \\
3 ø 2.4 \\
283.6 \\
238 . \varnothing \\
281.4 \\
275.2 \\
276.6 \\
238.4 \\
213.8 \\
269.8 \\
227.8 \\
245.6 \\
243.2 \\
261 . \varnothing \\
276.6\end{array}$ & $\begin{array}{l}3 ø 7.8 \\
247.4 \\
248 . \varnothing \\
312.2 \\
24 \varnothing .6 \\
257.6 \\
283.2 \\
271 . \varnothing \\
285 . \varnothing \\
323.6 \\
321.8 \\
3 ø 2.4 \\
281 . \varnothing \\
311.6 \\
321.4 \\
3 ø 2.2 \\
334.4 \\
3 ø 5 . \varnothing \\
271.6 \\
3 ø 1.4 \\
315.6 \\
3 ø 5.2 \\
255.6 \\
231.6 \\
29 \varnothing . \varnothing \\
243.6 \\
255.6 \\
262 . \varnothing \\
292 . \varnothing \\
3 ø 4 . \varnothing\end{array}$ & $\begin{array}{l}326.2 \\
246.4 \\
275.4 \\
347.8 \\
262.2 \\
287.6 \\
3 ø 8.8 \\
291.4 \\
318 . \varnothing \\
348.8 \\
358.6 \\
332 . \varnothing \\
322 . \varnothing \\
337 . \varnothing \\
352.2 \\
336.8 \\
362.8 \\
332.4 \\
29 ø .2 \\
335.2 \\
347.4 \\
345 . \varnothing \\
27 ø . \varnothing \\
255.8 \\
333.8 \\
27 \varnothing .4 \\
242.2 \\
286 . \varnothing \\
324.6 \\
34 \varnothing .2\end{array}$ & $\begin{array}{l}354.8 \\
243 . \varnothing \\
32 ø .1 \\
396.2 \\
3 ø \varnothing .9 \\
339.7 \\
35 \varnothing .4 \\
321.1 \\
364.2 \\
387.1 \\
413 . \varnothing \\
37 ø .8 \\
371.8 \\
377.1 \\
4 ø 6.1 \\
39 ø .4 \\
413.9 \\
366.3 \\
328.3 \\
383.6 \\
4 ø 3.2 \\
388.3 \\
295.9 \\
288.6 \\
386.7 \\
3 ø 9.5 \\
239.2 \\
333.8 \\
381.9 \\
4 ø 1 . \emptyset\end{array}$ & $\begin{array}{r}40.6 \\
\varnothing .4 \\
64.8 \\
79 . \emptyset \\
7 \varnothing .2 \\
73.7 \\
74.2 \\
46.5 \\
76.6 \\
69.8 \\
84.1 \\
92.3 \\
82.2 \\
71.2 \\
72.1 \\
9 ø .5 \\
88.1 \\
52.4 \\
76.2 \\
72.9 \\
82.3 \\
71.1 \\
38.6 \\
54.3 \\
92.8 \\
64.7 \\
\varnothing .9 \\
74 . \emptyset \\
93.7 \\
94.4\end{array}$ & $\begin{array}{l}1 \\
\varnothing \\
1 \\
1 \\
1 \\
1 \\
1 \\
1 \\
1 \\
1 \\
1 \\
1 \\
1 \\
1 \\
1 \\
1 \\
1 \\
1 \\
1 \\
1 \\
1 \\
1 \\
1 \\
1 \\
1 \\
1 \\
\varnothing \\
1 \\
1 \\
1\end{array}$ & $\begin{array}{l}314.3 \\
242.6 \\
255.3 \\
317.2 \\
23 \varnothing .7 \\
266 . \varnothing \\
276.1 \\
274.6 \\
287.6 \\
317.3 \\
328.8 \\
278.5 \\
289.5 \\
3 ø 5.9 \\
334 . \varnothing \\
299.9 \\
325.7 \\
313.9 \\
252.2 \\
310.8 \\
320.9 \\
317.9 \\
257.3 \\
234.3 \\
293.9 \\
244.7 \\
238.2 \\
259.8 \\
288.2 \\
3 ø 6.6\end{array}$ & $\begin{array}{r}37.3 \\
8.8 \\
34.3 \\
62.2 \\
19.5 \\
44.6 \\
4 \varnothing .9 \\
51.8 \\
48.4 \\
5 \varnothing .9 \\
57.9 \\
32.3 \\
57.7 \\
62.5 \\
76.8 \\
47.9 \\
53.5 \\
52.9 \\
25.2 \\
63.4 \\
70.5 \\
75.6 \\
3 \varnothing .7 \\
32.9 \\
46.5 \\
31.3 \\
13.8 \\
28.4 \\
45.6 \\
58.4\end{array}$ & $\begin{array}{r}8 \\
12 \\
15 \\
14 \\
15 \\
14 \\
12 \\
16 \\
13 \\
16 \\
17 \\
15 \\
13 \\
17 \\
17 \\
16 \\
9 \\
17 \\
15 \\
15 \\
14 \\
7 \\
13 \\
26 \\
13 \\
15 \\
17 \\
17\end{array}$ & $\begin{array}{r}8 \\
12 \\
15 \\
14 \\
14 \\
14 \\
9 \\
16 \\
12 \\
16 \\
17 \\
14 \\
13 \\
14 \\
17 \\
16 \\
9 \\
16 \\
15 \\
15 \\
14 \\
7 \\
11 \\
26 \\
13 \\
115 \\
16 \\
17\end{array}$ & $\begin{array}{l}\emptyset \\
\vdots \\
\emptyset \\
\emptyset \\
1 \\
\emptyset \\
3 \\
\emptyset \\
1 \\
\emptyset \\
\emptyset \\
\emptyset \\
\emptyset \\
2 \\
\emptyset \\
\emptyset \\
\emptyset \\
1 \\
\emptyset \\
\emptyset \\
\emptyset \\
\emptyset \\
2 \\
\emptyset \\
\emptyset \\
\dot{\emptyset} \\
1 \\
\emptyset\end{array}$ & 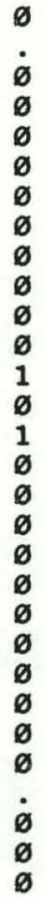 & 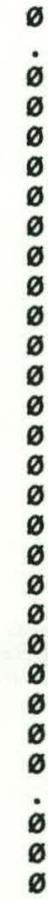 \\
\hline
\end{tabular}


TMT $=4 \varnothing \mathrm{ppm}$

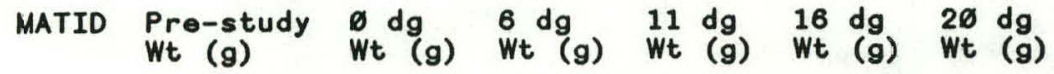

UTERWT PREG XGESWT XGESGN IMPLANT LIVE EARLY LATE DEAD

$235 . \varnothing 233.2$

244.8

250.8

245.6

232.4

256.2

281.2

उø8. 347.2

217.4235 .4

286.6

251.8 277.2
282.6

$254.6 \quad 271.8$

296.2

341.8

284.4

$3 \varnothing 5.6$

213.8

$234 . \varnothing 249.4$

219.6248.

268.2

321.2

359.3
269.3

22.3

383.6
344.6

350.4

254.8

253.4273 .0

252.9

297.4
325.8

352.2

379.1

309.2

61.6
63.7
67.8
88.3
71.5
82.7
81.6
$8 ø .1$
58.9
1.2
78.7
76.5
11.5
9.6
9.4
58.8
68.5
61.7
9.5
83.6
76.5
82.3
72.3
73.1
44.1
56.5
8.8
78.3
96.3

285.6
295.7
254.4
294.6
273.1
267.8
$27 \varnothing .6$
$299 . \varnothing$
250.3
284.9
293.4
287.6
293.1
227.2
273.5
280.3
282.3
292.3
275.4
277.6
277.3
289.9
262.9
285.8
264.1
$248 . \varnothing$
245.9
325.8
$316 . \varnothing$

52.4
46.9
37.6
46.6
44.5
33.8
51.6
45.6
36.1
15.5
42.8
52.0
63.1
16.6
56.3
35.9
33.3
53.5
23.6
44.8
36.7
47.5
27.9
34.4
56.7
17.4
-98.1
48.6
56.4

\begin{tabular}{|c|c|c|c|}
\hline $\begin{array}{l}13 \\
12\end{array}$ & $\begin{array}{l}12 \\
12\end{array}$ & $\begin{array}{l}1 \\
\emptyset\end{array}$ & $\emptyset$ \\
\hline $\begin{array}{l}14 \\
17 \\
15 \\
16 \\
16 \\
18 \\
12\end{array}$ & $\begin{array}{l}13 \\
17 \\
15 \\
16 \\
16 \\
15 \\
11\end{array}$ & $\begin{array}{l}1 \\
\emptyset \\
0 \\
\varnothing \\
0 \\
3 \\
1\end{array}$ & $\begin{array}{l}\dot{\emptyset} \\
\emptyset \\
\emptyset \\
\emptyset \\
\emptyset \\
\emptyset \\
\emptyset\end{array}$ \\
\hline $\begin{array}{r}17 \\
15 \\
2\end{array}$ & $\begin{array}{r}16 \\
16 \\
2\end{array}$ & $\begin{array}{l}i \\
\emptyset \\
\emptyset\end{array}$ & $\begin{array}{l}\dot{\emptyset} \\
\emptyset\end{array}$ \\
\hline • & • & - & • \\
\hline $\begin{array}{l}14 \\
15 \\
11\end{array}$ & $\begin{array}{l}12 \\
14 \\
11\end{array}$ & $\begin{array}{l}i \\
1 \\
\varnothing\end{array}$ & $\begin{array}{l}i \\
\emptyset \\
\emptyset\end{array}$ \\
\hline $\begin{array}{r}14 \\
15 \\
16 \\
15 \\
15 \\
9 \\
10\end{array}$ & $\begin{array}{r}14 \\
15 \\
16 \\
14 \\
14 \\
9 \\
10\end{array}$ & $\begin{array}{l}\emptyset \\
\varnothing \\
\emptyset \\
1 \\
1 \\
\varnothing \\
\varnothing\end{array}$ & $\begin{array}{l}\dot{\emptyset} \\
\emptyset \\
\emptyset \\
\emptyset \\
\emptyset \\
\emptyset \\
\emptyset\end{array}$ \\
\hline $\begin{array}{l}18 \\
16\end{array}$ & $\begin{array}{l}16 \\
16\end{array}$ & $\begin{array}{l}2 \\
\emptyset\end{array}$ & $\stackrel{\emptyset}{\emptyset}$ \\
\hline
\end{tabular}

248.4

209.4

206.8

215.4

279.

304.4

285.2

394.6

227.7

231.0

216.6224.

223.2251 .2

$249.0 \quad 273.4$

292.2

350.8

225.8

238.8

258.0

287.8

316.2

220.8

233.6

$232.8 \quad 251.6$

285.8

332.0

353.8

287.4

$276.2 \quad 299.8$

$297.4 \quad 319.6$

251.4272 .4

$230.6 \quad 233.8$

4

283.6

335.2

358

298.5

222.8

$277.8 \quad 316.8$

345.4378 .8

404.0
412.3

96.3

316.8

56.4 
TMT $=2 ø \emptyset \mathrm{ppm}$

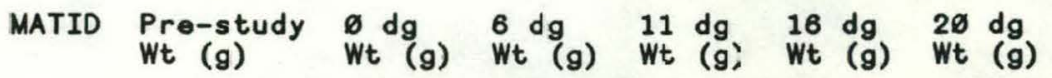

UTERWT PREG XGESWT XGESGN IMPLANT LIVE EARLY LATE DEAD

238.2
247.4
242.4
246.4
261.8
245.4
257.8
219.4
262.4
214.4
212.4
$22 \varnothing .8$
222.8
231.6
$2 \varnothing 4.6$
211.6
246.6
225.8
261.4
222.6
228.8
219.8
251.6
237.8
245.8
247.4
225.4
$259 . \varnothing$
231.6
244.4

$\begin{array}{ll}245 . \varnothing & 271 . \varnothing \\ 241.6 & 264.6 \\ 247 . \varnothing & 268 . \varnothing \\ 245.2 & 254.4\end{array}$

302.0

325.4

353.9
393.3

$285.6 \quad 319.6$

291.6

338.6

$245.2 \quad 254.4$

$252 . \varnothing \quad 277.6$

347.6 487.7 367.5
393.5

$\begin{array}{rl}56.3 & 1 \\ 71.1 & 1 \\ 73.8 & 1 \\ 86.4 & 1 \\ 61.3 & 1 \\ 83.4 & 1 \\ 74.4 & 1 \\ 76.3 & 1 \\ 45 . \emptyset & 1 \\ 87.6 & 1 \\ 72.2 & 1 \\ 36.0 & 1 \\ 82.9 & 1 \\ 62.1 & 1 \\ 6.8 & 0 \\ 72.5 & 1 \\ 93.9 & 1 \\ 61.3 & 1 \\ 87.2 & 1 \\ 86.7 & 1 \\ 75.4 & 1 \\ 79.3 & 1 \\ 78.2 & 1 \\ 62.5 & 1 \\ 6.4 & 0 \\ 6.3 & \wp \\ \varnothing .6 & \wp \\ 97 . \varnothing & 1 \\ 79.7 & 1 \\ 78.5 & 1 \\ & \end{array}$

297.7
322.1
289.2
321.2
366.2
310.1
277.8
$279 . \varnothing$
$387 . \varnothing$
365.8
252.6
273.3
$298 . \varnothing$
260.6
246.3
272.4
316.4
287.8
321.9
314.1
252.8
273.8
283.4
$295 . \varnothing$
264.6
277.1
249.8
336.1
$286 . \varnothing$
262.3

52.7

80.5

42.2

45.6

58.1

$285.6 \quad 367.8$

314.6

352.2

346.2

339.8379 .8

432.6

$289.2 \quad 311.2$

$\begin{array}{llll}239.6 & 268.0 & 365.8 & 340.8\end{array}$

267.8

284.8

324.9

232.4253 .0

$229.8 \quad 249.8$

288.8

325.6

$38 \varnothing .8$

217.4251 .820 .8

247.1

297.4
365.0

419.3

318 .

$269.2 \quad 301.6$

340.1 $227 . \varnothing 242.6$ $269.4 \quad 293.2$

$36 \varnothing .8$

490.8

277.8

328.2

$227.6 \quad 233.8$

367.4

(353.0

$259.2 \quad 273.8295 .6$

277.4

$\begin{array}{llll}248.6 & 271.2 & 278.4 & 268.8\end{array}$

$261.4 \quad 264.0 \quad 278.4$

283.8

357.5

265.8

277.4

$262.0 \quad 286.9 \quad 331.4$

371.2

433.1

365.7

78.5

262.3

52.2

97.8

66.2

46.9

30.8

28.9

45.4

56.8

6 6. 8

52.5

25.2

49.8

24.2

43.0

16.0

15.7

27.6

74.1

12.3

$\begin{array}{rr}12 & 12 \\ 17 & 14 \\ 16 & 15 \\ 15 & 15 \\ 13 & 11 \\ 17 & 17 \\ 17 & 16 \\ 15 & 15 \\ 13 & 8 \\ 16 & 15 \\ 14 & 14 \\ 7 & 7 \\ 16 & 16 \\ 15 & 12 \\ 13 & 13 \\ 18 & 17 \\ 16 & 14 \\ 17 & 17 \\ 15 & 15 \\ 16 & 16 \\ 17 & 16 \\ 17 & 15 \\ 15 & 12 \\ . & . \\ . & : \\ 18 & 18 \\ 16 & 16 \\ 16 & 16\end{array}$

\begin{tabular}{|c|c|c|}
\hline$\emptyset$ & $\emptyset$ & 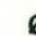 \\
\hline 3 & $\emptyset$ & 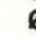 \\
\hline 1 & $\varnothing$ & 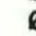 \\
\hline$\emptyset$ & $\emptyset$ & 8 \\
\hline 2 & $\emptyset$ & 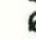 \\
\hline$\varnothing$ & $\emptyset$ & $\varepsilon$ \\
\hline 1 & D & e \\
\hline$\emptyset$ & $\emptyset$ & 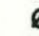 \\
\hline 5 & $\emptyset$ & 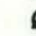 \\
\hline 1 & $\varnothing$ & 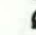 \\
\hline$\emptyset$ & $\emptyset$ & 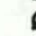 \\
\hline ø & $\varnothing$ & 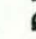 \\
\hline$\emptyset$ & $\varnothing$ & 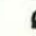 \\
\hline 3 & D & \\
\hline$\varnothing$ & $\dot{g}$ & 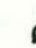 \\
\hline 1 & $\varnothing$ & 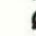 \\
\hline 2 & $\varnothing$ & \\
\hline$\varnothing$ & $\emptyset$ & 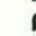 \\
\hline$\emptyset$ & $\emptyset$ & \\
\hline$\emptyset$ & $\varnothing$ & 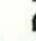 \\
\hline 1 & $\emptyset$ & 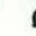 \\
\hline 2 & $\emptyset$ & \\
\hline 1 & 2 & \\
\hline • & • & \\
\hline - & • & \\
\hline$\emptyset$ & $\dot{\varnothing}$ & \\
\hline & $\varnothing$ & \\
\hline ஜ & $\emptyset$ & \\
\hline
\end{tabular}




\section{$T M T=1 \varnothing \varnothing \varnothing \mathrm{ppm}$}

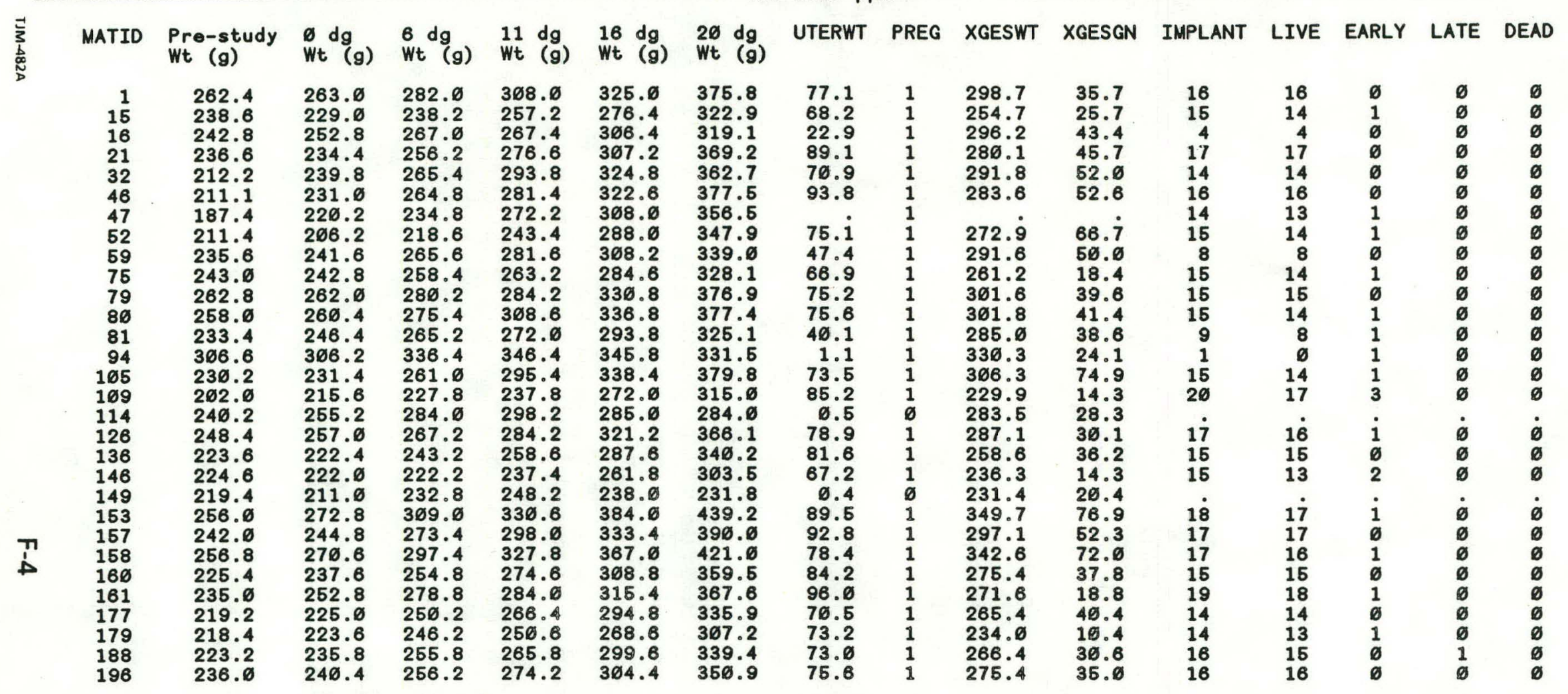


APPENDIX G

MALFORMATIONS AND VARIATIONS IN INDIVIDUAL

RAT FETUSES EXPOSED TO 1,3-BUTADIENE 


\begin{tabular}{|c|c|c|c|c|c|}
\hline Mat ID & 3 & 22 & 28 & 30 & 51 \\
\hline \multicolumn{6}{|l|}{ Number examined: } \\
\hline Fetuses & 8 & 12 & 15 & 14 & 14 \\
\hline Heads & 4 & 6 & 8 & 7 & $?$ \\
\hline Hydroureter & 6 & 3 & 7 & $1,11,13$ & \\
\hline \multicolumn{6}{|l|}{ Reduced Ossification: } \\
\hline Sternebrae $1-6$ & $1-8$ & $1-12$ & $1-15$ & $1-14$ & $1,3-15$ \\
\hline Sternebrae $1-4$ & & $2,8,10,12$ & $9,10,11,13$ & 12 & $5-9,11,12,14,15$ \\
\hline Ribs & & & 8 & & \\
\hline Skull & & & $4,6,10,12$ & $4,6,10$ & 13,15 \\
\hline $\begin{array}{c}\text { Thoracic vertebra } \\
\text { (centra) }\end{array}$ & 3,8 & & $1,2,4-7,9-13$ & $2,3,5,6,8,9,10,: 2$ & $1,7,11,12$ \\
\hline Pelvis & & & 8 & & \\
\hline Mat ID & 61 & 66 & 68 & 85 & 92 \\
\hline \multicolumn{6}{|l|}{ Number examined: } \\
\hline Fetuses & 14 & 9 & 16 & 12 & 16 \\
\hline Heads & 7 & 4 & 8 & 6 & 8 \\
\hline Vessel Defect & & & & & 13 \\
\hline Hydroureter & $1,4,5,10,14$ & 3,5 & 11 & & 3,16 \\
\hline Pale & & & & & 13 \\
\hline \multicolumn{6}{|l|}{ Reduced Ossification: } \\
\hline Sternebrae 1-6 & $1-14$ & $2-7,9,10,12$ & $1-16$ & $1-3,6,8,12,13$ & $1-16$ \\
\hline Sternebrae $1-4$ & $1,3,5-10,12,14$ & & 1,2 & & 13 \\
\hline Ribs & & & & & . \\
\hline Skull & & 2,4 & $9,11,15$ & & \\
\hline $\begin{array}{c}\text { Thoracic vertebra } \\
\text { (centra) }\end{array}$ & $6-8,12,13$ & 2,7 & $1-3,8,10-13,15,16$ & & $1,3-5,8,11,12,14$ \\
\hline
\end{tabular}




\begin{tabular}{|c|c|c|c|c|c|}
\hline Mat ID & 95 & 98 & 104 & 115 & 121 \\
\hline \multicolumn{6}{|l|}{ Number examined: } \\
\hline Fetuses & 17 & 14 & 13 & 14 & 17 \\
\hline Heads & 9 & 7 & 7 & 7 & 8 \\
\hline \multicolumn{6}{|l|}{ Edema } \\
\hline Hydroureter & & 3,5 & & & 9 \\
\hline \multicolumn{6}{|l|}{ Reduced Ossification: } \\
\hline Sternebrae $1-6$ & $1-17$ & $1-7,9-15$ & $1-13$ & $2-6,8,10-17$ & $1-17$ \\
\hline Sternebrae $1-4$ & $1,10,15$ & $2,3,5-7,9,10,14$ & & 3 & $6,7,11-13$ \\
\hline Skull & & 14 & & 11 & 3 \\
\hline \multicolumn{6}{|l|}{ Thoracic vertebra } \\
\hline Pelvis & & $2,3,13$ & $5,10,12,13$ & 8 & $\begin{array}{c}5-10,13,16,17 \\
1,8\end{array}$ \\
\hline Mat ID & 122 & 123 & 124 & 28 & 151 \\
\hline \multicolumn{6}{|l|}{ Number examined: } \\
\hline Fetuses & 16 & 9 & 16 & 15 & 15 \\
\hline Heads & 8 & 5 & 8 & 7 & ${ }^{8}$ \\
\hline Hydroureter & $5,6,10,12-14,16$ & & & & 7 \\
\hline \multicolumn{6}{|l|}{ Reduced Ossification: } \\
\hline Sternebrae 1-6 & $1-3,5-7,11,14,16$ & $1-9$ & $1-12,14-17$ & $i-15$ & 13,14 \\
\hline Sternebrae 1-4 & & & 1 & 1 & \\
\hline Skull & & 6 & & 1 & $4,6,10,12,14$ \\
\hline \multicolumn{6}{|l|}{ Thoracic vertebra } \\
\hline (centra) & & 2 & $1,7-11,16$ & 4 & $5,13-15$ \\
\hline Pelvis & . & & & 1 & 1 \\
\hline Phalanges & & 6 & & & \\
\hline
\end{tabular}


o ppm

\begin{tabular}{|c|c|c|c|c|c|}
\hline Mat ID & 156 & 162 & 165 & 170 & 173 \\
\hline \multicolumn{6}{|l|}{ Number examined: } \\
\hline Fetuses & 14 & 7 & 11 & 20 & 13 \\
\hline Heads & 7 & 4 & 5 & 10 & 7 \\
\hline Edema & & & & & $\sigma$ \\
\hline Hydroureter & $2,13,14$ & & 9,11 & 7 & \\
\hline \multicolumn{6}{|l|}{ Reduced Ossification: } \\
\hline Sternebrae 1-6 & $1-14$ & $1-7$ & $1-6,8,9,11-13$ & $1-20$ & $1-13$ \\
\hline Sternebrae 1-4 & & & & $4,7,9-14,18,19$ & 6,13 \\
\hline Ribs & & & 12 & & \\
\hline Skull & & & & & 12 \\
\hline \multicolumn{6}{|l|}{ Thoracic vertebra } \\
\hline \multirow{2}{*}{ Pelvis (centra) } & 5,9 & 3 & & 3,8 & $1-5,8,10-13$ \\
\hline & & 4 & & & 2,10 \\
\hline Mat ID & 180 & 181 & 190 & & \\
\hline \multicolumn{6}{|l|}{ Number examined: } \\
\hline Fetuses & 15 & 16 & 17 & & \\
\hline Heads & 8 & 8 & 8 & & \\
\hline Hydroureter & & 11,12 & 3 & & \\
\hline Reduced Ossification: & & & & . & \\
\hline Sternebrae $1-6$ & $1-15$ & $1,3-11,13,16,17$ & $1-17$ & & \\
\hline Sternebrae $1-4$ & & 1 & & & \\
\hline Skull & 2 & & & & \\
\hline Thoracic vertebra & & & . & & \\
\hline (centra) & 2 & $1,3,8,15,16$ & $1,2,5,7,10,11$ & & \\
\hline
\end{tabular}


$40 \mathrm{ppm}$

\begin{tabular}{|c|c|c|c|c|c|}
\hline Lat ID & 8 & 14 & 26 & 31 & 37 \\
\hline \multicolumn{6}{|l|}{ Number examined: } \\
\hline Fetuses & 12 & 12 & 13 & 17 & 15 \\
\hline Heads & 6 & 6 & 6 & 9 & .7 \\
\hline Hydrocephaly & & & 13 & & 8 \\
\hline Hydroureter & & 8,12 & & $3,4,12$ & 15 \\
\hline \multicolumn{6}{|l|}{ Reduced Ossification: } \\
\hline Sternebrae 1-6 & $1-5,7-13$ & $1-12$ & $1,2,4,5,9 ; 11,13$ & $1-3,5-17$ & $1,3,4,9-13,15$ \\
\hline Sternebrae 1-4 & $3,5,8$ & & & 16 & 3 \\
\hline Skull & 11 & & $1,6,14$ & 12,16 & 3 \\
\hline \multicolumn{6}{|l|}{ Thoracic vertebra } \\
\hline (centra) & $1,2,4,5,7,12$ & 2,4 & 2 & $6,13-15$ & $2-5,8,11$ \\
\hline Mat ID & 50 & 60 & 62 & 69 & 101 \\
\hline \multicolumn{6}{|l|}{ Number examined: } \\
\hline Fetuses & 16 & 16 & 15 & 11 & 16 \\
\hline Heads & 8 & 8 & 8 & 5 & 8 \\
\hline Hydroureter & $1-3,11,12$ & & 8 & & 4 \\
\hline \multicolumn{6}{|l|}{ Reduced Ossification: } \\
\hline Sternebrae 1-6 & $1,2,4-16$ & $1-16$ & $1-5,7,8,10-12,14-18$ & $\therefore-10,12$ & $1-14,16,17$ \\
\hline Sternebrae $1-4$ & & & $3,5,7,11$ & $1,6,7,10$ & \\
\hline Skull & 4 & & 2 & & \\
\hline Thoracic vertebra & & & & & \\
\hline (centra) & $2,5,7,15$ & $1-3,5,6,12,14$ & 3,11 & 1,4 & $2,3,5,7-9,12,14,16$ \\
\hline
\end{tabular}


$40 \mathrm{ppm}$

\begin{tabular}{|c|c|c|c|c|c|}
\hline Mat ID & 102 & 106 & 113 & 116 & 138 \\
\hline \multicolumn{6}{|l|}{ Nhumber examined: } \\
\hline Fetuses & 15 & 2 & 12 & 14 & 11 \\
\hline Heads & 8 & 1 & 6 & 7 & 6 \\
\hline Hydroureter & $1,11,12$ & 1,2 & 2 & 5,9 & 3,10 \\
\hline \multicolumn{6}{|l|}{ Reduced Ossification: } \\
\hline Sternebrae 1-6 & $1-14$ & 1,2 & $1-9,11,13,14$ & $1-11,13-15$ & $1-11$ \\
\hline Sternebrae 1-4 & & & 9 & $1,2,11$ & \\
\hline Ribs & & & & 14 & 2 \\
\hline Skull & & & 9 & $2,6,10,13$ & \\
\hline \multicolumn{6}{|l|}{$\begin{array}{c}\text { Thoracic vertebra } \\
\text { (centra) }\end{array}$} \\
\hline Mat ID & 145 & 148 & 155 & 166 & 171 \\
\hline \multicolumn{6}{|l|}{ Number examined: } \\
\hline Fetuses & 14 & 15 & 16 & 14 & 14 \\
\hline Heads & 7 & 7 & 8 & 7 & 7 \\
\hline Hydrocephaly & & & & & 1 \\
\hline Hydroureter & $4,6,10,12$ & 8 & 6 & $4,5,8-11$ & \\
\hline \multicolumn{6}{|l|}{ Reduced Ossification: } \\
\hline Sternebrae 1-6 & $1-14$ & $1-12,14$ & $1=16$ & $1,2,4-14$ & $1-8,10-15$ \\
\hline Sternebrae 1-4 & & & $1,3-5,9,10,12-16$ & 5,11 & 12,14 \\
\hline Skull & & & & $2,5,15$ & 6 \\
\hline $\begin{array}{l}\text { Thoracic vertebra } \\
\text { (centra) } \\
\text { Phalanges }\end{array}$ & $1,7,10,12,13$ & $2,8,10-13$ & $2,3,12,16$ & $\begin{array}{c}10,14 \\
4-9\end{array}$ & $1,2,4,5,7,8,11-15$ \\
\hline
\end{tabular}




\begin{tabular}{|c|c|c|c|c|}
\hline & & \multicolumn{3}{|c|}{$40 \mathrm{ppm}$} \\
\hline Mat ID & 186 & 194 & 201 & 202 \\
\hline \multicolumn{5}{|l|}{ Number examined: } \\
\hline Fetuses & 9 & 10 & 16 & 16 \\
\hline Heads & 5 . & 5 & 8 & 8 \\
\hline Edema & & & $1,2,4$ & \\
\hline Extra ribs & & & 10 & \\
\hline \multicolumn{5}{|l|}{ Reduced Ossification: } \\
\hline Sternebrae $1-6$ & $1-9$ & $1-10$ & $1-5,7-10,12-18$ & $1,3-16$ \\
\hline Sternebrae $1-4$ & $1,4-8$ & 3,4 & $1-3,7,10,15$ & $=1-14$ \\
\hline Skull & 2 & 6,8 & & 5 \\
\hline $\begin{array}{c}\text { Thoracic vertebra } \\
\text { (centra) }\end{array}$ & $1,4,7$ & & & \\
\hline
\end{tabular}

a 
200 ppm

\begin{tabular}{|c|c|c|c|c|c|}
\hline Mat ID & 5 & 17 & 24 & 29 & 33 \\
\hline \multicolumn{6}{|l|}{ Number examined: } \\
\hline Fetuses & 12 & 14 & 15 & 15 & 11 \\
\hline Heads & 6 & 7 & 8 & 7 & $\epsilon$ \\
\hline Hydroureter & 5,11 & & $4,6,7,9-14,16$ & 7 & 5,8 \\
\hline Misaligned Sternebrae & & & & 5 & \\
\hline \multicolumn{6}{|l|}{ Reduced Ossification: } \\
\hline Sternebrae 1-6 & $1-12$ & $1-5,9,11,12,14,15,17$ & $2-6,9-16$ & $1,3-15$ & $2,4-13$ \\
\hline Sternebrae 1-4 & $2,3,6,8,10,12$ & & & $1,4-6,8-10,12,11,15$ & 5 \\
\hline Skull & & 10 & 11 & 11,15 & 4 \\
\hline \multicolumn{6}{|l|}{ Thoracic vertebra } \\
\hline (centra) & 4 & $9,11,14,15$ & $2,3,8,14,15$ & $3,4,8,9,12$ & $2,4-6,9,12$ \\
\hline Pelvis & & 9,12 & & & \\
\hline Mat ID & 35 & 36 & 40 & 41 & 48 \\
\hline \multicolumn{6}{|l|}{ Number examined: } \\
\hline Fetuses & 17 & 16 & 15 & 8 & 15 \\
\hline Heads & 8 & 8 & 7 & 4 & 7 \\
\hline \multirow{2}{*}{\multicolumn{6}{|c|}{ Misaligned Sternebrae }} \\
\hline & & & & & \\
\hline \multicolumn{6}{|l|}{ Reduced Ossification: } \\
\hline Sternebrae 1-6 & $1-16$ & $1-16$ & $1,2,4-15$ & $1,5,6,8,12,1 \equiv$ & $2-13,15,16$ \\
\hline Sternebrae $1-4$ & 5 & 12 & $6,8-10,14$ & 13 & \\
\hline Skull & & & $1,3,5$ & & $1,3,5,9,11,16$ \\
\hline Thoracic vertebra & & & & & \\
\hline (centra) & & 14 & & 5,13 & $4,10,13$ \\
\hline Pelvis & & & 6 & & 13 \\
\hline
\end{tabular}


200 ppm

\begin{tabular}{|c|c|c|c|c|c|}
\hline Mat ID & 57 & 70 & 82 & 83 & 110 \\
\hline \multicolumn{6}{|l|}{ Number examined: } \\
\hline Fetuses & 14 & 7 & 16 & 12 & 13 \\
\hline Heads & 7 & 3 & 8 & 6 & 6 \\
\hline Hydroureter & & & 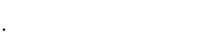 & & $3,5,8,13$ \\
\hline Missing ribs & & , & & 7 & \\
\hline \multicolumn{6}{|l|}{ Reduced Ossification: } \\
\hline Sternebrae $1-6$ & $1-14$ & $1-7$ & $1-16$ & $1,2,4-7,9-12,14,15$ & $1-13$ \\
\hline Sternebrae $1-4$ & $1,2,6,12$ & $1-6$ & $3,8,10$ & 1 & $5,7,8,11$ \\
\hline Ribs & 10 & & & $1,7,12$ & \\
\hline \multicolumn{6}{|l|}{ Thoracic vertebra } \\
\hline (centra) & 3,10 & $1-3,5-7$ & 12,13 & 9, Ji & 3 \\
\hline Mat ID & 118 & 119 & 127 & 130 & 131 \\
\hline \multicolumn{6}{|l|}{ Number examined: } \\
\hline Fetuses & 17 & 14 & 17 & 15 & 16 \\
\hline Heads & 9 & 7 & 8 & 8 & 8 \\
\hline Hydroureter & 13 & & 13 & $1,2,4,8-11$ & \\
\hline Missing Ribs & $11,16,17$ & & & & \\
\hline Missing Innominate Artery & & & $1-11$ & & \\
\hline \multicolumn{6}{|l|}{ Reduced Ossification: } \\
\hline Sternebrae $1-6$ & $1-13,15-18$ & $1-7,9-14,16$ & $1-17$ & $1-9,11-15$ & $1-16$ \\
\hline Sternebrae 1-4 & $1,10,11$ & $1-6,9-14,16$ & $7,8,10$ & 1.5 & $1,2,4,5,7-12,14,15$ \\
\hline Ribs & & & 7 & & \\
\hline Skull & 4 & & 7 & & 5 \\
\hline \multicolumn{6}{|l|}{ Thoracic vertebra } \\
\hline (centra) & $1-3,5,7,11$ & $1,6,7,9,10,13,14$ & $5,6,8-10,16$ & & $1,3-5,7,13,16$ \\
\hline Pelvis & 10 & & 7 & & \\
\hline
\end{tabular}


200 ppm

$200 \mathrm{ppm}$

\begin{tabular}{|c|c|c|c|c|c|}
\hline Mat ID & 133 & 140 & 163 & 184 & 187 \\
\hline \multicolumn{6}{|l|}{ Number examined: } \\
\hline Fetuses & 16 & 15 & 12 & 18 & 16 \\
\hline Heads & 8 & 8 & 6 & 9 & 8 \\
\hline Edema & & & & & $6{ }^{\star}$ \\
\hline Hydroureter & & & 1,5 & & 7,16 \\
\hline Missing ribs & & · & & & 6 \\
\hline \multicolumn{6}{|l|}{ Reduced Ossification: } \\
\hline Sternebrae $1-6$ & $1-13,15-17$ & $1-9,11,13-17$ & $1,3-5,7-11,13,15$ & $1-18$ & $1-7,9-16$ \\
\hline Sternebrae $1-4$ & $2-8,10-13,16$ & $3,5,15$ & $7,8,11$ & & \\
\hline Skull & & 11 & & & \\
\hline $\begin{array}{c}\text { Thoracic vertebrae } \\
\text { (centra) } \\
\text { Lumbar vertebrae }\end{array}$ & 16 & & 11,14 & & $\begin{array}{c}5,6,9,10,11,15 \\
6\end{array}$ \\
\hline
\end{tabular}

a ${ }^{*}$ This fetus also had aortic stenosis, undescended testes, bent tibia, low ear set and reduced ossification of tibia and fi

\begin{tabular}{lc}
\multicolumn{1}{c}{ Mat ID } & 197 \\
\hline $\begin{array}{l}\text { Number examined: } \\
\text { Fetuses }\end{array}$ & 16 \\
Heads & 8 \\
Hydroureter & 8 \\
Extra rib & 6 \\
Reduced Ossification: & \\
Sternebrae 1-6 & $1-16$ \\
Sternebrae 1-4 & 3,6 \\
Phalanges & 3,6
\end{tabular}




\begin{tabular}{|c|c|c|c|c|c|}
\hline \multirow[b]{2}{*}{ Mat ID } & \multicolumn{5}{|c|}{$1000 \cdot \mathrm{ppm}$} \\
\hline & 1 & 15 & 16 & 21 & 32 \\
\hline \multicolumn{6}{|l|}{ Number examined: } \\
\hline Fetuses & 16 & 14 & 4 & 17 & 14 \\
\hline Heads & 8 & 8 & 2 & 8 & 7 \\
\hline Hydroureter & 9 & & & $=1,17$ & \\
\hline \multicolumn{6}{|l|}{ Reduced Ossification: } \\
\hline Sternebrae 1-6 & $1-16$ & $.1,3-15$ & $1-4$ & $1-17$ & $1-14$ \\
\hline Sternebrae $1-4$ & 6,8 & $1,4,5,13$ & 1,2 & 8,9 & \\
\hline Ribs & & & - & & 10 \\
\hline Skull & & & & 3 & $2,8,14$ \\
\hline \multicolumn{6}{|l|}{ Thoracic vertebra } \\
\hline (centra) & $1,6,12,15$ & $3,9-12$ & 3,4 & $2,8.9$ & 8 \\
\hline Pelvis & & & & 2 & \\
\hline Mat ID & 46 & 47 & 52 & 59 & 75 \\
\hline \multicolumn{6}{|l|}{ Number examined: } \\
\hline Fetuses & 16 & 13 & 14 & $\mathbf{8}$ & 14 \\
\hline Heads & 8 & 6 & 7 & 4 & 7 \\
\hline Cystic dilation" & & 4 & & & \\
\hline Hydroureter & $2,5,6,8,12,14,16$ & $3,4,7,11-13$ & & $\Xi$ & \\
\hline \multicolumn{6}{|l|}{ Misaligned Sternebrae } \\
\hline \multicolumn{6}{|l|}{ Reduced Ossification: } \\
\hline Sternebrae $1-6$ & $1-12,14-16$ & $1-6,9-14$ & $1-7,9-11,13-15$ & $1-8$ & $1-5,7-15$ \\
\hline Sternebrae $1-4$ & & & 9 & & \\
\hline Skull & & & 3,14 & $3,5,7$ & $10,12,14$ \\
\hline Thoracic vertebra & $2,3,5,6,8,10,11,15$ & $1,4-6,9-11$ & & & \\
\hline (centra) & & & & $3,4,6,8$ & 1,11 \\
\hline Pelvis & & & 3 & & \\
\hline
\end{tabular}

*Between meninges and skull. 


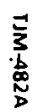

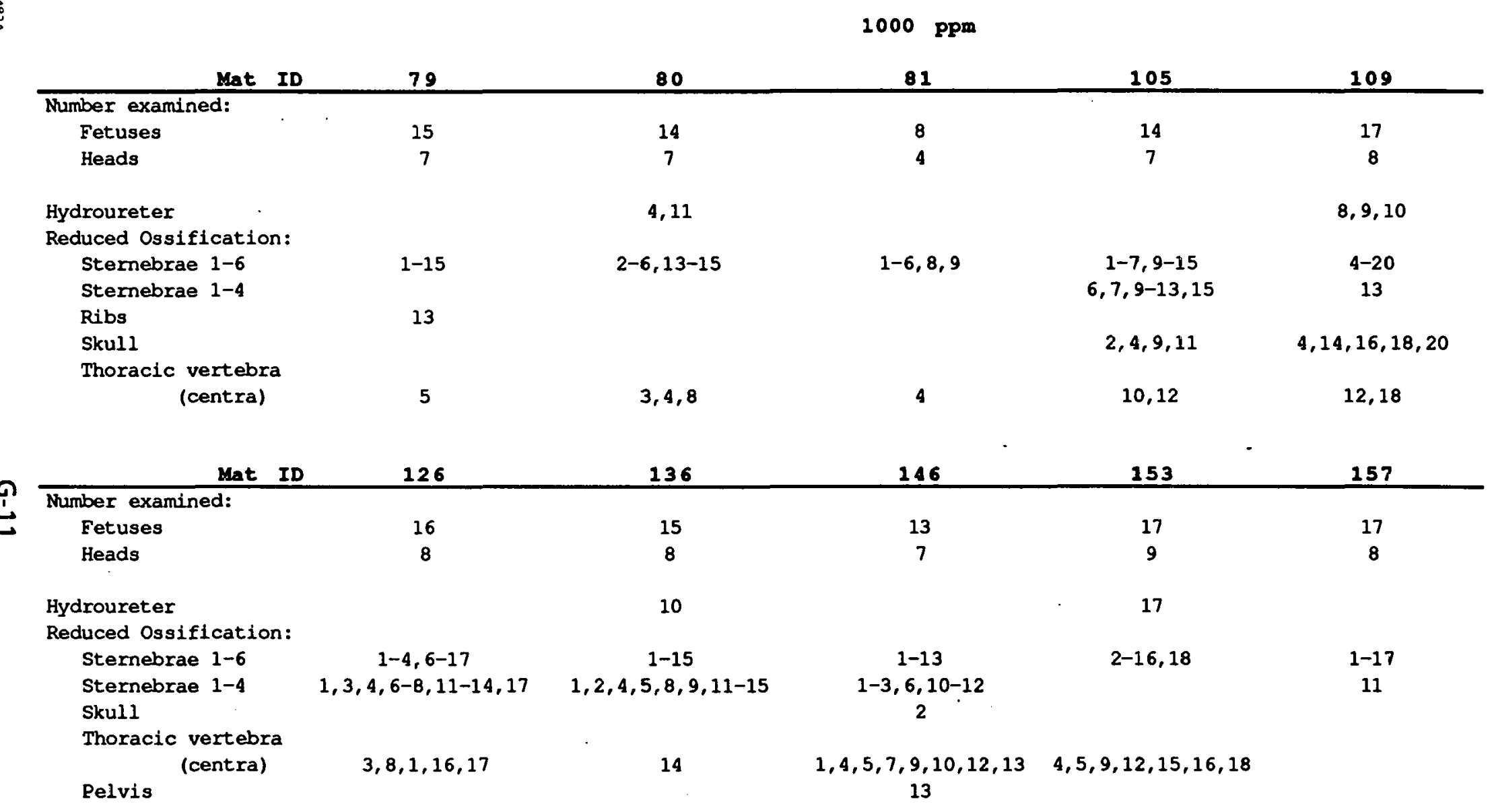


1000 ppm

\begin{tabular}{|c|c|c|c|c|c|}
\hline Mat ID & 158 & 160 & 161 & 177 & 179 \\
\hline \multicolumn{6}{|l|}{ Number examined: } \\
\hline Fetuses & 15 & 15 & 18 & 14 & 13 \\
\hline Heads & 7 & 7 & 9 & 7 & 7 \\
\hline Hydroureter & & & 7 & $3,6: 7,11,13$ & \\
\hline \multicolumn{6}{|l|}{ Reduced Ossification: } \\
\hline Sternebrae 1-6 & $1,2,4,6,10-12,15-17$ & $1-15$ & $1-10,12-14,16-18$ & $1,4-9,11-14$ & $1-13$ \\
\hline Sternebrae 1-4 & & & & & $1,3,7,10$ \\
\hline Ribs & & & & 13 & \\
\hline Skull & & 5,15 & & & 2 \\
\hline Thoracic vertebra & & & & & \\
\hline (centra) & 8,17 & 6 & 10 & 2,3 & $1,3,5,9,14$ \\
\hline - Pelvis & & & 6 & & \\
\hline Mat ID & 188 & 196 & & & \\
\hline \multicolumn{6}{|l|}{ Number examined: } \\
\hline Fetuses & 15 & 16 & & & \\
\hline Heads & 8 & 8 & & & \\
\hline Edema & $9,14,16$ & & & & \\
\hline Meningoencephalocele & 9,14 & & & & \\
\hline Aphakia/retinal dysgen & 14 & & . & & \\
\hline Microphthalmia & 16. & & & & \\
\hline Hydroureter & & 7 & & & \\
\hline Misaligned Sternebrae & & 6 & & & \\
\hline Reduced Ossification: & & . & & & \\
\hline Sternebrae $1-6$ & $1-7,9-11,13-16$ & $1-16$ & & & \\
\hline Sternebrae $1-4$ & 16 & $1,6-11,13,14,16$ & & & \\
\hline Skull & & $3,5,11,15$ & & & \\
\hline \multicolumn{6}{|l|}{ Thoracic vertebra } \\
\hline (centra) & 8 & $4,7,12$ & & & \\
\hline Pelvis & & 15 & & & \\
\hline
\end{tabular}




\section{APPENDIX H}

QUALITY ASSURANCE STATEMENT, SAMPLE AND RECORD

DISPOSITION, SCHEDULE OF EVENTS, AND

REPRODUCTIVE INDICES FROM RAT

1,3-BUTADIENE DATA 


\title{
TERATOLOGY STUDY OF 1,3-BUTADIENE \\ IN RATS \\ (Final Report)
}

\author{
Quality Assurance Statement
}

I, isted below are phases andlor procedures included in the study described in this report which were reviewed by the Quality Assurance Unit during the period $10 / 01 / 85$ - 03/01/86 or specifically for this study and the dates the reviews were performed and findings reported to management. (All findings were reported to the study director or his degignee at the time of the review.)

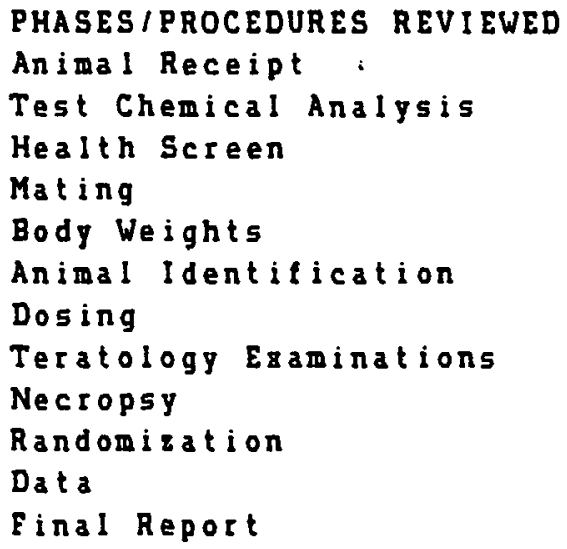

PHASES / PROCEDURES REVIEWED

Animal Receipt

Test Chemical Analysis

Health Screen

Mating

Body Weights

Animal Identification

Dosing

Teratology Eaminations

Necropsy

Randomization

Data

Einal Report

\section{DATE FINDINGS SUBMITTED \\ IN WRITING TO \\ STUDY DIRECTOR/MANACEMENT}

$11 / 01 / 85$

$12 / 02 / 85$

$11 / 15 / 85$

$11 / 26 / 85$

$12 / 02 / 85$

$12 / 02 / 85$

$12 / 06 / 85$

$12 / 16 / 85$

$1 / 08 / 86$

$1 / 09 / 86$

$2 / 11 / 86$

$11 / 20 / 87$

* Reviewed specifically for this study.

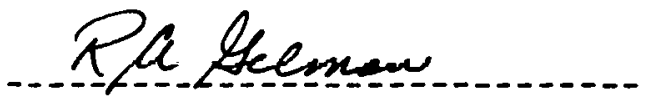

Ouality Assurance Specialist
$-11 / 20 / 87$

Date 
Upon completion of the 1,3-butadiene studies, all tissue and fetal specimens will be shipped to the National Toxicology Program (NTP) Archives. Records generated in the conduct of the study will be microfiched. Computer tapes of biological data, the original and two copies of the microfiche, and the microfiche index will be sent to Dr. Schwetz (National Institute of Environmental Health Sciences) for storage in NTP Archives.

The Quality Assurance Unit at Pacific Northwest Laboratory (PNL) will retain all documents and records associated with the conduct of the study for a period of at least 2 years following completion of the study. These materials will be placed in Room 1433 of the Life Sciences Laboratory-ll building at PNL according to 21 CFR 58.195. NTP will be notified of the completion of the storage period so that they may specify the terms of the disposition of these records. 


\section{CALENDAR OF EVENTS FOR TERATOLOGY STUDY OF 1,3-BUTADIENE IN THE RAT}

Completion of exposure/monitoring system: 9/15/85

Approval of protocol:

Animal order:

Receipt of animals:

Initial health screen:

Overnight cohabitation:

Detection of copulation ( $0 \mathrm{dg}$ )

Exposure period (6-19 dg)

Sacrifice (20 dg)

Completion of fetal examinations:

Completion of statistical evaluations:

Submission of Draft Report:

Submission of Final Report
$10 / 22 / 85$

10/02/85 (CD Sprague-Dawley-derived rats from Charles River Laboratories, Portage Facility, MI)

10/30/85 (ARC \#860010; 205 females; ARC \#860009; 105 males; date of birth, 09/05/85)

$11 / 13 / 85$

$11 / 18 / 85$ to $11 / 22 / 85$
(A) $11 / 19 / 85$
(B) $11 / 20 / 85$
(C) $11 / 21 / 85$
(D) $11 / 22 / 85$
(E) $11 / 23 / 85$
(A) $11 / 25 / 85$ to $12 / 04 / 85$
(B) $11 / 26 / 85$ to $12 / 05 / 85$
(C) $11 / 27 / 85$ to $12 / 06 / 85$
(D) $11 / 28 / 85$ to $12 / 07 / 85$
(E) $11 / 29 / 85$ to $12 / 08 / 85$
(A) $12 / 09 / 85$
(B) $12 / 10 / 85$
(C) $12 / 11 / 85$
(D) $12 / 12 / 85$
(E) $12 / 13 / 85$

$01 / 15 / 86$

03/03/86

(1) June 1986

(2) April 1987

November 1987 
No. of

Copies

\section{OFFSITE}

2 Technical Information Center

Dr. M. L. Minthorn

U.S. Department of Energy

ER-72, GTN

Washington, DC 20545

10 Dr. R. E. Morrissey and

Dr. B. A. Schwetz

National Toxicology Program -NIEHS

Alexander Drive

Building 101, Room D440

Research Triangle Park, NC 27709

Mr. Larry Travis

National Institute of

Environmental Health Sciences

Contracts Management Office, OAM

79 Alexander, Building 4401

Post Office Box 12874

Research Triangle Park, NC 27709

\section{ONSITE}

DOE Richland Operations Office

J. J. Sutey/D. L. Sours

13 Pacific Northwest Laboratory

E. M. Crow (2)

R. A. Gelman

P. L. Hackett

T. J. Mast

M. R. Sikov

Publishing Coordination (2)

Technical Report Files 